Menoufia J. Agric. Economic \& Social Sci. Vol. 5 April (2020): 55 - 89

\author{
المشكلات الإجتماعية للمرأة الريفية ببعض قري محافظة المنوفية \\ فؤاد عبد اللطيف سلامة، خالد عبد الفتاح على قنيبر، فرحات عبد السيد محمد، \\ مروة صالح الزفزاف \\ قسم الإرشاد الزراعي والمجتمع الريفي ـ كلية الزراعة ـ جامعة المنوفية - مصر مرور
}

Received: Feb. 2, 2020

Accepted: Feb. 9, 2020

الملخص

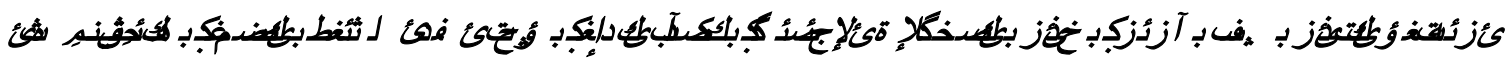

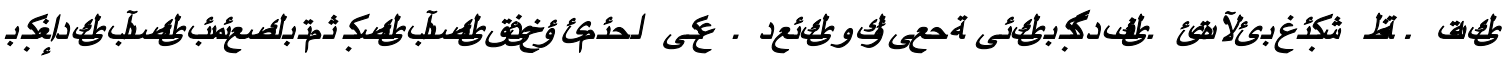

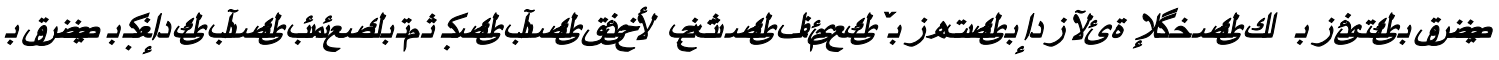

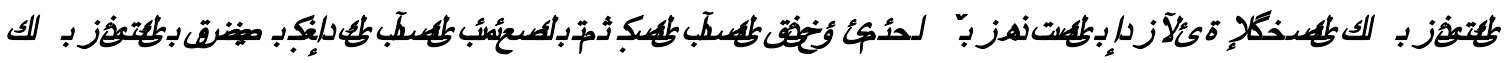

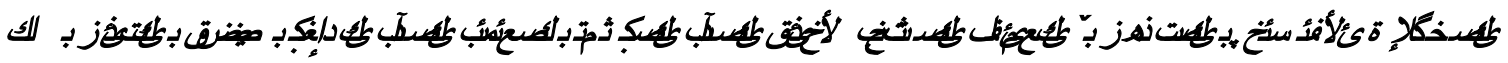

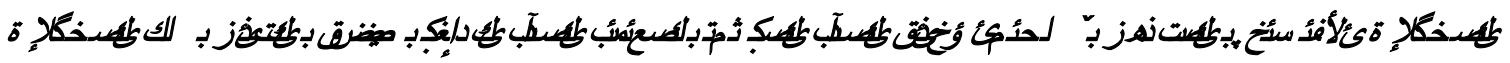

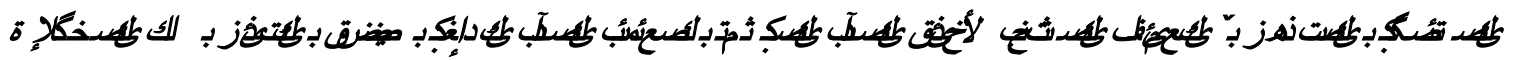

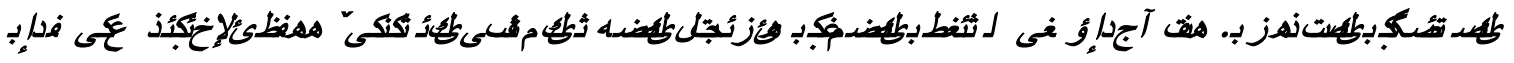

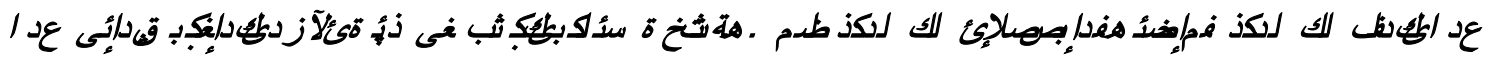

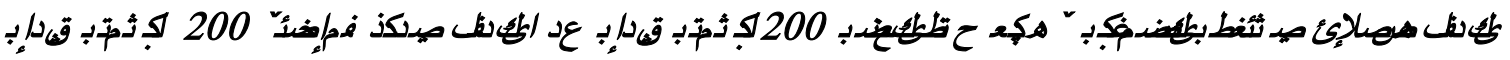

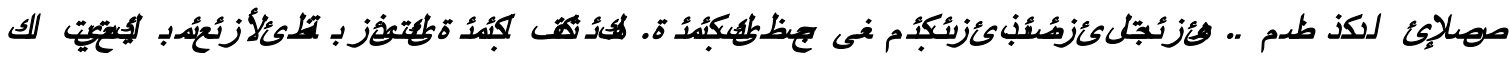

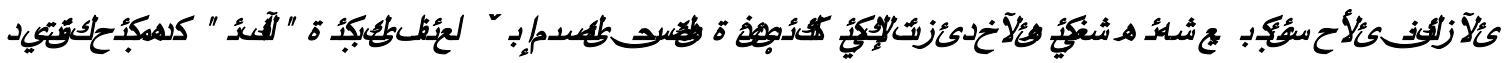

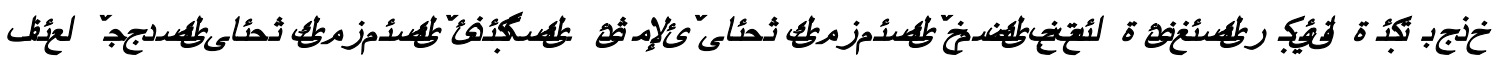

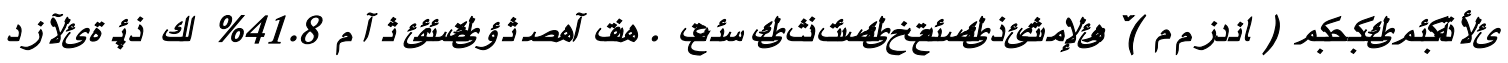

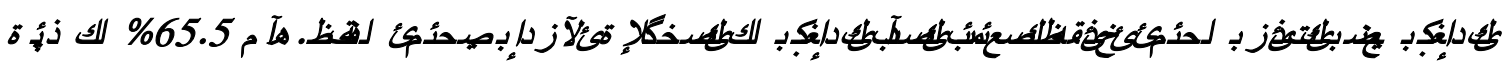

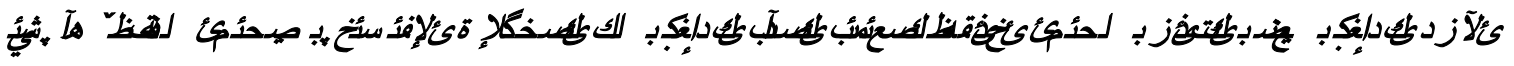

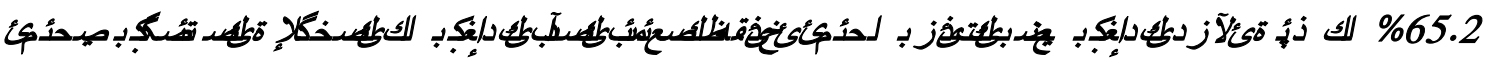

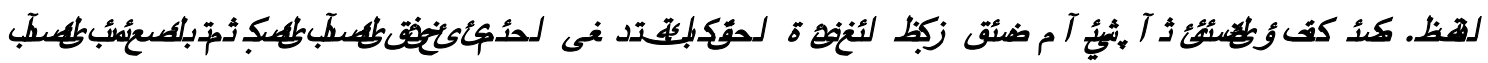

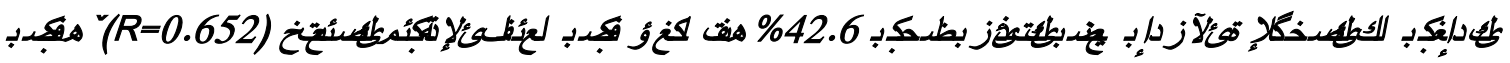

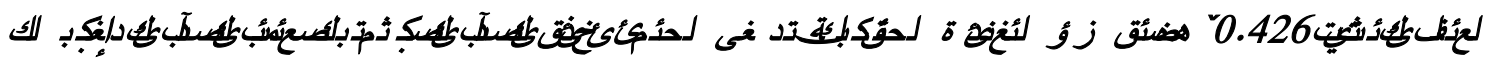

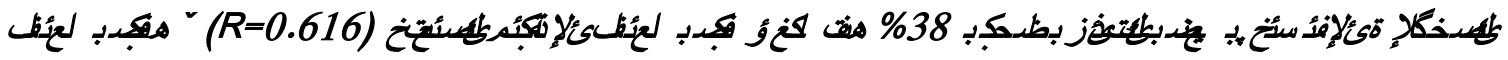

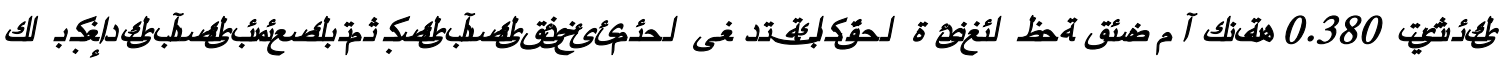

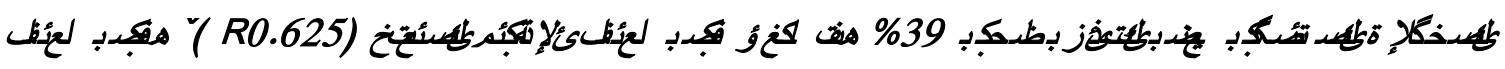

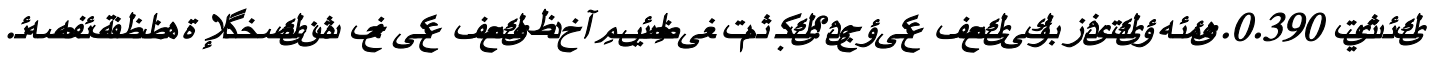

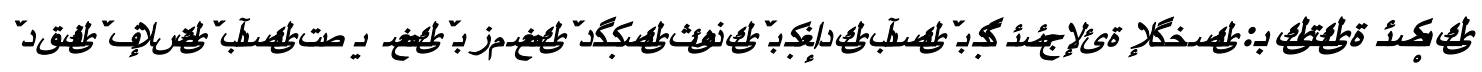

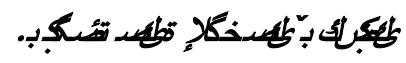


سـنة مـن سـنن الحيـاة، فمنــنــــيم الأزل تواجـه المـرأة العديد من الصعوبات نتيجة التفرقة العنصرية الجنسية، فكونها امرأة هو السبب الأول وقد يكون الوحيد وراء الكثير من الصعوبات التي قد تواجهها المرأة في حياتها المهنية مهما كانت مهنتها ومهما تغيرت بيئة العمل التي تحسيط بهـا. مسن هـا المنطلق تزايــا الاهتمسام العـالمي بالمشكلات الاجتماعيـة التي تعاني منها المرأة الريفيـة وتعوقهـا مـن تأديـة أدوارهـا الحياتيـة المتعددة، فـالمرأة الريفية بوصفها نصف المجتمع الريفي، والراعية لكل

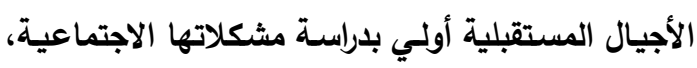
ومـن هنـا تقتضـي الحاجـة إلـي ضـرورة وتضسافر كافـة

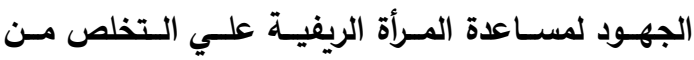
مشكلاتها الاجتماعية وتحريرها منها، ومن ثم العمل علي رقي وعلو شأنها والنهوض بها، ومن ثم إصلاح أحوال المجتمـعـ وفي ضـوء ذلـك يتحتم إجـراء هـذه الدراســة

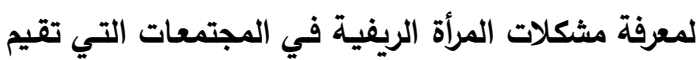
فيها وتقديم التوصيات اللازمة لمعالجتها.

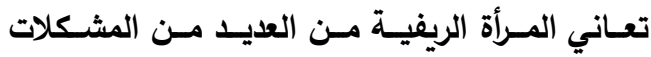

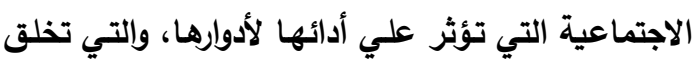

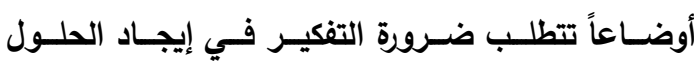
المناسبة لها. ووجود هذه المشاكل ظاهرة توجد في كافة

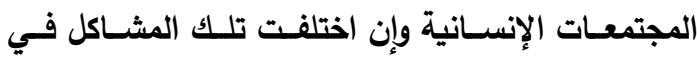
عددها ونوعها ودرجـة خطورتها من مجتمـع لآخر تبعاً

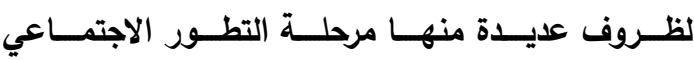

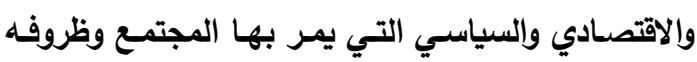
الاقتصادية والاجتماعية.

وتعتبر كل ظاهرة تعوق المرأة عن القيام بواحد أو أو أكثر من أدوارهـا الاجتماعية مثكلة اجتماعية، ويمكن فئن القول أن هناك مجموعة كبيرة من المشكلات الاجتماعية الهاجية

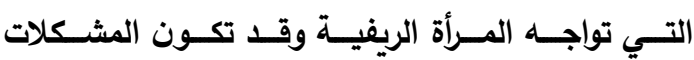
الاجتماعيـة محسل اتفــاق بـين الدارسـين الاجتمـاعيين

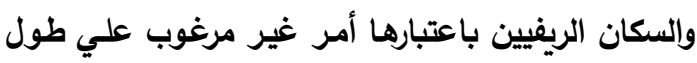
الخط. ومسن جهة أخري قد تكون المشكلة الاجتماعية
المقدمة والمشكلة البحثية

تؤثر المشكلات الاجتماعية التي تصيب المجتمعات

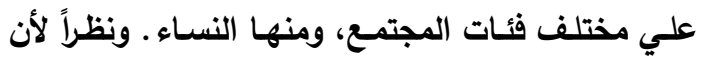

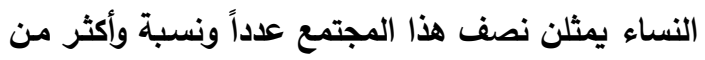

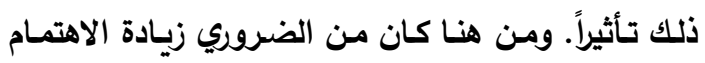

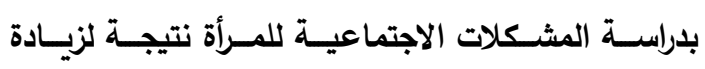

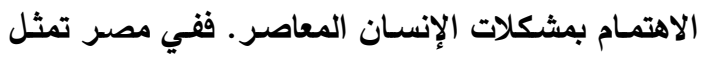

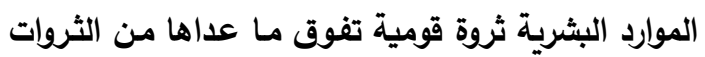
الأخرى حيث يقـدر عـد السـكان بجـوالي 92 مليـون

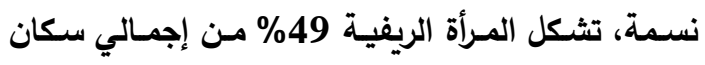
مصـر طبقـا للتعـداد 2016 (الجهـاز المركـزي للتعبئـة العامـة والإحصـاء، 2016)، وعلـي ذلك فـالمرأة الريفيـة تمثل رصيداً لا يستهان به من القوي البشرية، وتعد ثروة قومية هائلة وقوة رئيسية في الإنتاج لو أحسن استثمارها

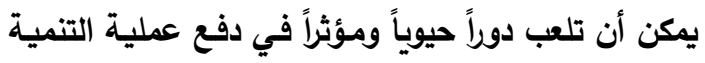

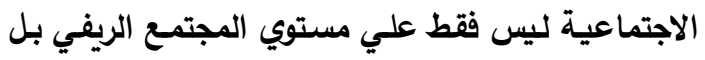
علي مستوي المجتمع ككل. وإذا كانت المشاكل تملأ حياة

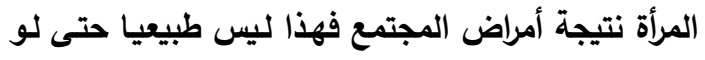

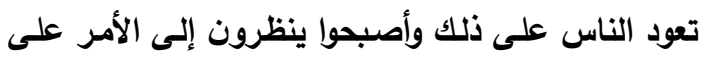
أنه سنة من سنن الحياة، فمنذ قديم الأزل تواجه المرأة العديد من الصعوبات نتيجة التفرقة العنصرية الجنسية، فكونها امرأة هو السبب الأول وقد يكون الوحيد وراء الكثير من الصعوبات التي قد تواجهها المرأة في حياتها المهنية مهما كانت مهنتها ومهما تغيرت بيئة العمل التي تحيط بها.

فقضـية المـرأة مـن جميـع وجوههـا قضـية إنسـانية

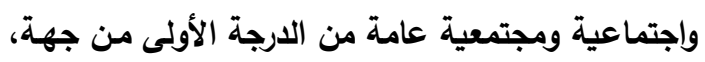
وقضية خاصة تتعلق باضطهاد المرأة وما تتعرض له من الهن من جنه أثنكال الظلم والاستفلال والقهر والعنف ومـا تعانيه من

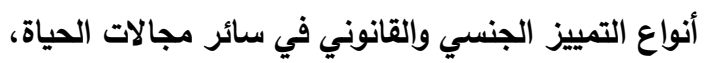
مسن جهـة أخرى. وإذا كانت المشـــل تمـلأ حيـاة المـرأة

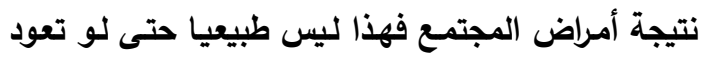
الناس على ذلك وأصبحوا ينظرون إلى الأمر على أنهـ 
3. مستوي إدراك المرأة المبحوثة لمعانـاة المرأة الريفية

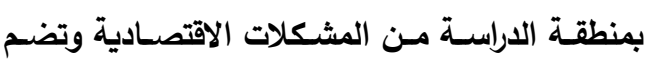

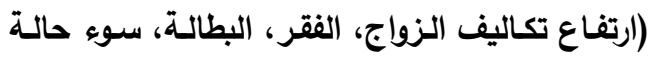
المسكن ). 4. العوامل المحددة لإدراك المرأة المبحوثة لمعاناة المرأة الريفيـة بمنطقة الدراسـة مـن المشكلات الاقتصـادية المدروسة.

5. مستوي إدراك المرأة المبحوثة لمعاناة المرأة الريفية بمنطقة الدراسة من المشكلات المجتمعية والمتمثلة في (مشكلة الدروس الخصوصية، ونقص خدمات

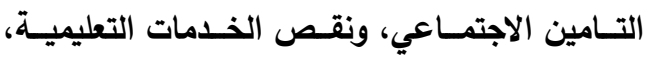
ونقص خدمات النقل والاتصـالات، ونقص خدمات الاتصن الأمسن، ونقص الخدمات الترفيهية، ونقص خدمات التصات

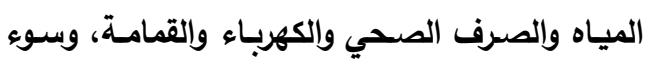
الخذمات الصحية ). 6. العوامل المحدة لإدراك المرأة المبحوثة لمعاناة المرأة الريفيـة بمنطقـة الدراسـة مـن المشكلات المجتمعيـة المدروسة.

$$
\text { الإطار المفهومي والنظري }
$$$$
\text { أولا : الإطار المفهومى المعي }
$$

$$
\text { 1- مفهوم المشكلات الاجتماعية }
$$

نظـراً لأن المشككلات الاجتماعيـة معقــدة ولا يمكن

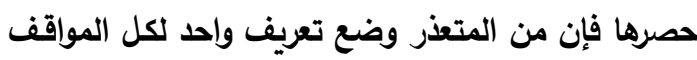

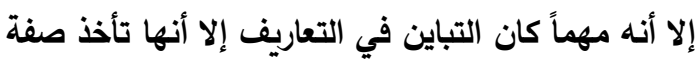
عامـة ومشـتركة. ويــكر سـلامة وآخـرون (غيـر مبـين

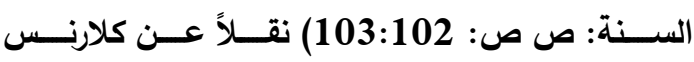
Clarence وتجذب اهتمامنا. وهو تعريف غير دقيق بالرغم من كثرة

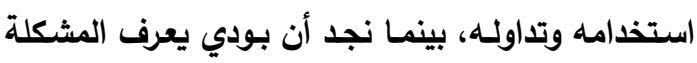
بأنها "ظاهرة تتكون من عدة أحداث أو وقائع متثـابكة

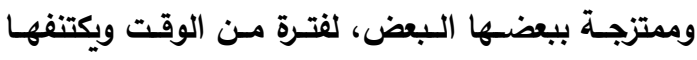

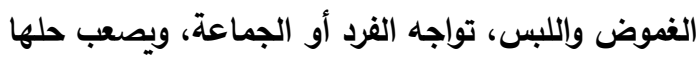

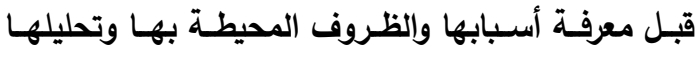

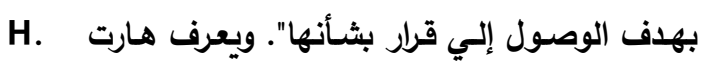

محل اختلاف نظراً لاختلاف وجهات النظر والتوجهات

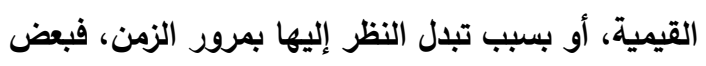

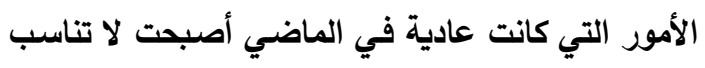

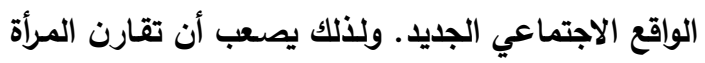

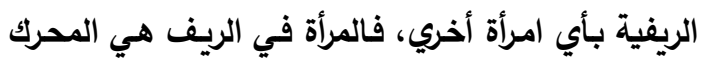
الأساسي للمنزل والأسرة، وهي الطرف الأكثر مسئولية

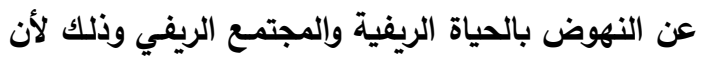

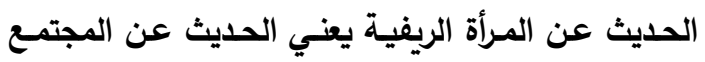

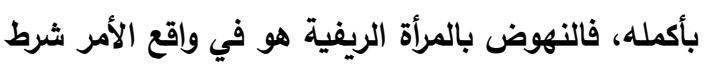
ضـروري لنهضـة مصـر ، ومسن خلالهـا يتحقـق إصـلاح

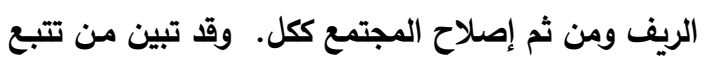

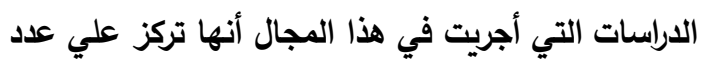

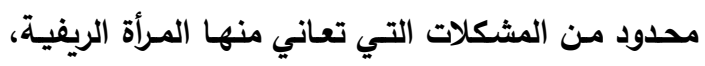

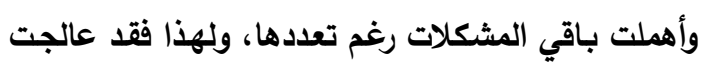

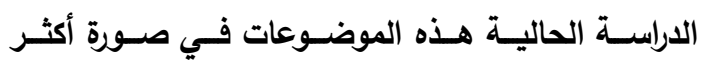

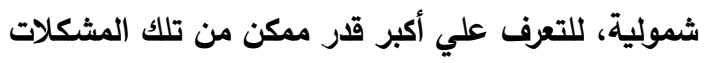

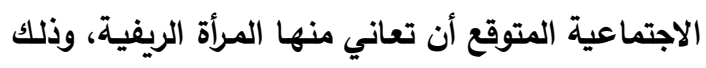
من أجل توفير قاعدة معلوماتية بالمشكلات التي تواجهها لمحاولة حلها أو احتوائها.

$$
\text { الأهداف البحثية }
$$

تسـتهدف هـــه الدراســة بصـفة أساسـية دراســة

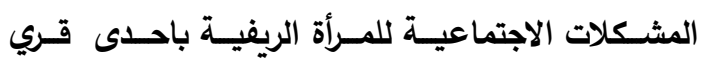

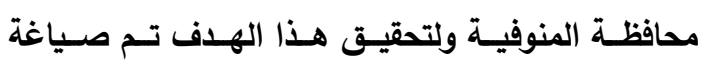
الأهداف الفرعية الآتية التي تسعي إلي التعرف علي: 1. مستوي إدراك المرأة المبحوثة لمعانـاة المرأة الريفية

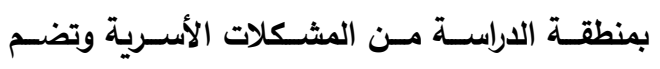
(العلاقات الأسرية، الزواج المبكر ، العنوسـة، الصراع

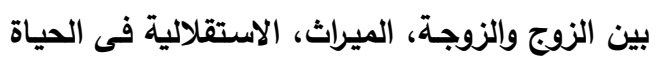

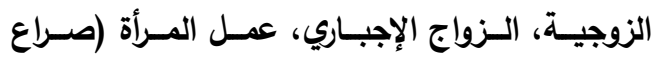

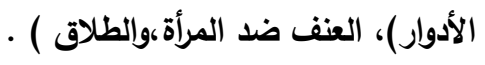
2. العوامل المحددة لإدراك المرأة المبحوثة لمعانـاة المرأة

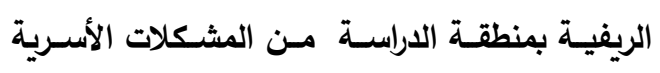
المدروسة. 


\section{F. A. Salama, et al.,}

ويرى الخولى (2007، ص:7) أنها انحراف سلوك

أفراد المجتمع عن القواعد الاجتماعية المحددة لتصرفات افراده، هذا الانحراف يفوق الحد التسامحى الذى حدده المجتمع، وأن هذه المشكلات تمثل تهديدا لأمن وسلاهة واستقرار المجتمع إذا لم يتم العمل الجماعى على دراستها وإيجاد حلول لها.

وذكرت هدى هليل (2009، ص: 14) أنها الوضع

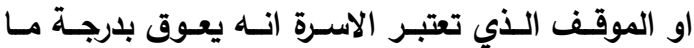
تحقيقها لوظائفها واستمتاعها بحياتها الاجتماعية. وتثسير سـماح المـلاح (2009، ص: 12) السى ان المشـكلة الاجتماعيـة سـلـوك يعيـق أداء الفـرد لأدواره الاجتماعية بطريقة سليمة، سواء كان ذلك السلوك صادرا عن الفرد نفسه او عن الاخرين. وفى هذا الصدد يتفق كلا من بيومى (2009، ص:

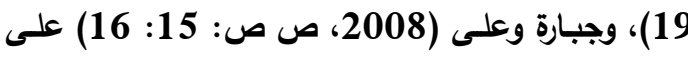
ان هناك عده عناصر يجب توافرها في تعريف المشكلات

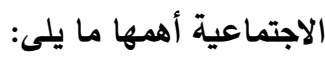

1. موقف او حالة او شكل متكرر من السلوك. 2-هذا الموقف او السلوك يؤثر في عدد كاف من الناس سواء بصورة مباشرة او غير مباشرة. 3-ان الحكم

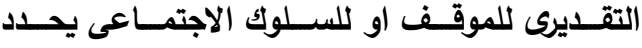

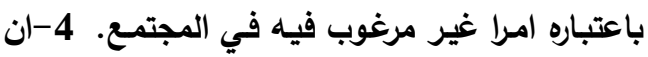
هذا الموقف او السلوك يهاد قيما اجتماعية. 5-ثقة أيمان عدد كاف من أعضـاء المجتمع بان شيئا ما يمكن القيام به بثأن تحسين أو تعديل الموقف غير المرغـوب فيـهـ مـن خـلال العمـل المشـترك وإلحسل

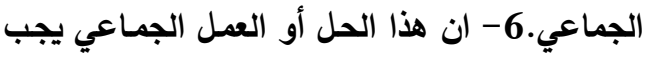
أن يتم من خلال فعل اجتماعي مناسب الى يجب أن أن إناعل يكون في الإطار النى تخلقت فيه المشكلة. وعلى هذا يعرفان المشكلة الاجتماعية بأنها موقف أو حالة في المجتمع اعتبرت خطيرة وغير مرغوب فيها مـن قبل المجتمـع ككل وهـى تركز على قيم اجتماعيـة ويعتقد بأنه في الإمكان تحنها أو علاجها.
Hart المشكلة الاجتماعيسة بأنها "المشكلة التـي تـؤثر

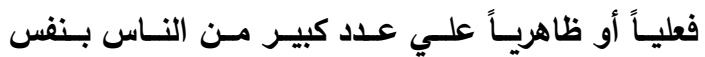

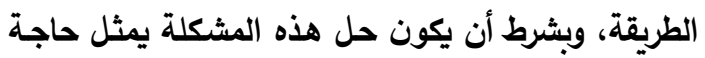
لاي غالبية هؤلاء الأفراد، وليس حاجة الفرد، ويتم الحل من خلال إجراء إنساني موجه ومركز".

ويعرفها هورتون وليسل Horton \& Leslie أيضاً بأنها "أي موقفف اجتمـاعي غير مرغوب فيهه مـن فئسة

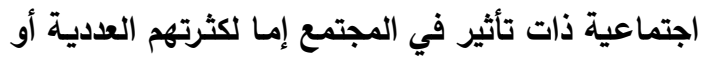

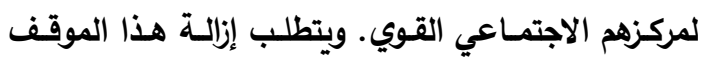
إجراء (فعل) اجتماعي مناسب للتخلص منهة.

وتعـددت التعـاريف التـي تناولــت مفهـوم المشـكلة الاجتماعيـة وذلك لتعدد التفسيرات التي تناولت قيامها ونشأتها من جانب، ولأهمية دراسة المشكلات الاجتماعية مسن جانـب اخر ، فمـنهم مسن ينظر إليهـا مسن منظور موضـوعى، ومـنهم مـن ينظر إليهـا مـن خـلال تحديــا مستوياتها المختلفة، ومنهه من ينظر إليها في ضوء الثروط الواجب توافرها فيما يمكن أن تطلق عليه مشكلة

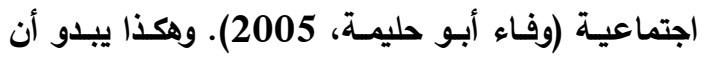
هناك جوانب مختلفة في تعريف المثكلة الاجتماعية. وفيما يلى عرضاً لأهم التعريفات التي تناولت مفهوم

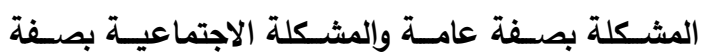

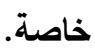

إذ يعني مفهوم المشكلة " وجود عائق أمسام الطريقة

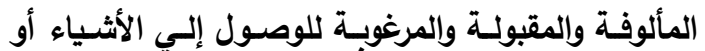
الأهداف الاجتماعية." (فرح وآخرون، 1999)

ويعرفها غيث (1981، ص ص: 15: 14) بأنها: أ- انحراف السلوك الاجتمـاعى عن القواعد التي حلدها

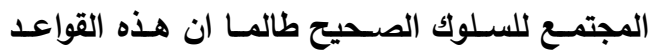

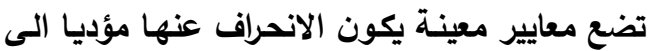
رد فعل واضح من الجماعه. ب- ويعرفها أيضا بأنها ما هي الا النتائج المباشرة وغير المباشرة، غير المرغوب فيها اجتماعيا والتي تترتب على تنظيم نمطى خاص لسلوك المجتمع. 


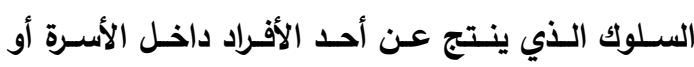

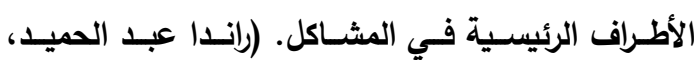
www.mammeto.com 2018) • وتضم المشكلات الأسرية فى البحث الحسالي

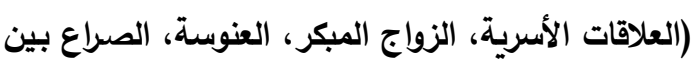

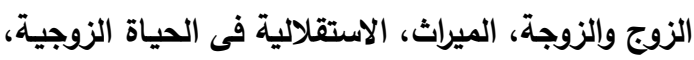

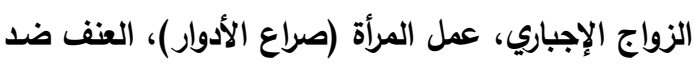
المرأة، والطلاق ) الاجباري، عمل

$$
\text { 3- المشكلات الاقتصادية }
$$

تعرف بأنها علدم القدرة علي إثباع جميع الاحتياجات

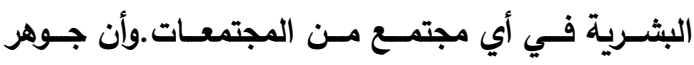

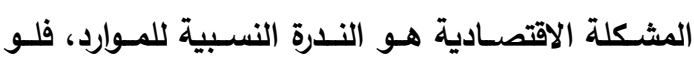

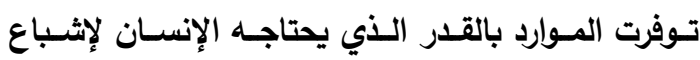

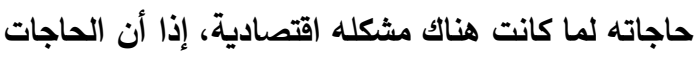

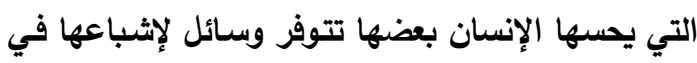

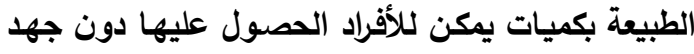

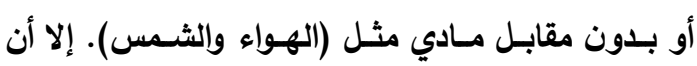

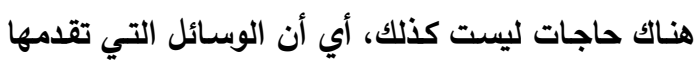

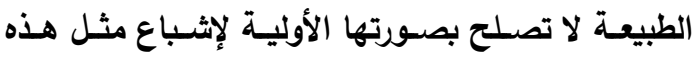

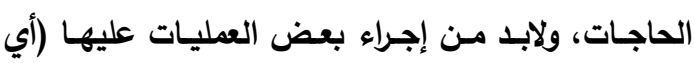

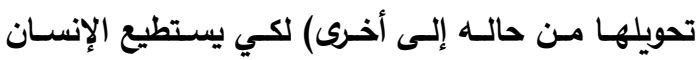
استعمالها والاستفادة منهـا لإثباع حاجاتـه (الثـمرى، الإنسان 2015، Uobabylon.edu.iq). وتضـــم المشــكلات الاقتصادية (ارتفاع تكاليف الزواج، الفقر، البطالة، سوء

$$
\text { 4- المشك المسكن ) • المشلات المجتمعية }
$$

إن مســولية المجتمـع تـوفير الرعايـة الاجتماعيـة

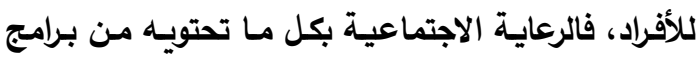
وخـدمات تهــف لــــم وحسـين الظـروف الاقتصـادية والصـية والقـدرات الثخصية للأفراد وتعتبر الخدمات المجتمعيـة احدي مكونـات الرعايـة الاجتماعيـة.وأهم مـا

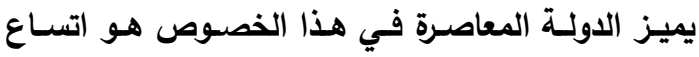
مجال الخدمات الأساسية التي تقدمها الدولة لمواطنيها
وتعرفها تحية أبو السعود (2016) بأنها الوضع أو

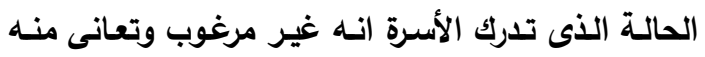
بارجة ما ويعوق أدائها لوظائفها. وتعرف المثكلة الاجتماعية في هذه الدراسـة علي أنها: هي التي تؤثر علي عدد كبير من الأفراد وتؤدي التئي إلي حدوث خلل في الوضع العام للمجتمع.

$$
\text { 2- مفهوم المشكلات الأسرية }
$$

تعد المشكلة الأسرية بمثابة وجود خلل أو قصور في الاستربه

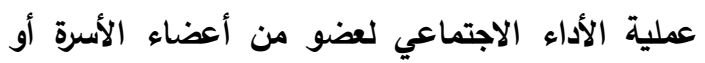
أكثر أي قصور في الأداء الوظيفي ويشكل حالة من الأن التفكك وعدم التكامل وعدم التوازن يبعد بالأسرة عن الأن التراء الأهداف العامة المشتركة التي يتوقع المجتمع منها لوعل

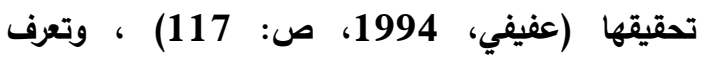

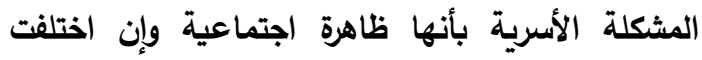
درجات حدتها، فلا يوجد مجتمع له مشاكل أسرية الهان ومجتمع آخر

تعرف المثكلة الأسرية أيضاً بأنها حالة من الانحلال نست العلاقات الأسرية نتيجة تفاعل عوامل داخلية وخارجية لعضو أو أكثر من جماعات الأسرة بما يؤدي لتئه إلي ظهور صراع بين الزوجين وتهديد بقاء واستمرار

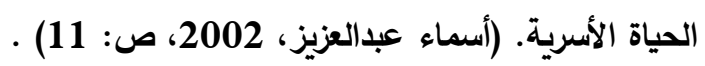
ويعرف الخولى (2007، ص: 93) المشكلة الأسرية بأنها حالة تؤثر علي عدد ليس بقليل من الأسر بطرق غير مرغوبة، ويوجد إحساس بأن هناك شئ يمكن عمله بله

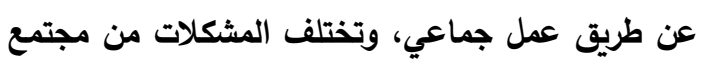
لأخر. وتعرف أمل العواودة وآخرين (2013) المشكلة الأسرية علي أنها شكل غير سوي من أشكال الأداء الوظيفي لادوار أفراد الأسرة.

تعرف المشكلات الأسرية أيضـاً علـي أنها نـوع من العلاقات غيـر المستقرة والمضطربة بـين أفراد الأسـرة الواحدة، ممـا يؤدي إلـي حدوث بعض التوترات سـواء 


\section{F. A. Salama, et al.,}

ثانيـاً: المــاخل النظريـة في دراسـة المشكلات الاجتماعية

انسه بسبب الكم الهائل من المشـاكل الاجتماعية لم يثبت اى محاولة للاقتراب نحو دراستها الرضا التام، فان مدخلا واحدا لاراستها لا يمكن أن يكون كافيا، لذلك توجد

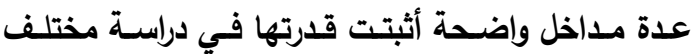
مواقف المثكلة. ( بيومي، 2009، صداف: 58 وفى هذا الصدد أورد كل من بيومي (1993، ص

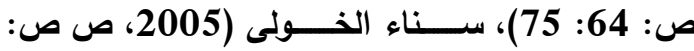
308: 314)، الخــــلى (2007، ص ص: 27: 32: 32) مداخل دراسة المثاكل الاجتماعية كما يلى:

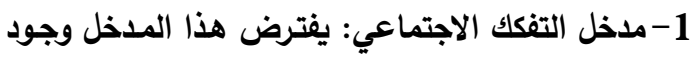
حالـة تماسك اجتمـاعي تسبق الاختلال أو التفكك، لكاعل فمع تتابع التغيرات المتلاحقة تتصارع المعايير والقيم الجديدة مع القديمة وتتناقض وتتصارع الأدوار، الأمر

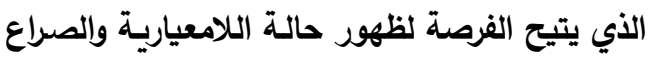

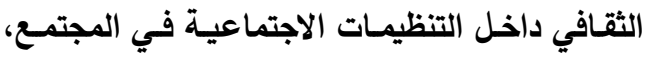
وهكذا يتبين أن أحد المسالك التي يسلكها التحليل الجيد للمشـاكل الاجتماعية يكون مـن خـلال تحليل التفكلك الاجتماعي الذي يصاحب التغير الاجتماعي.

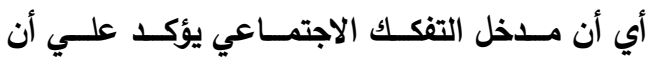
المجتمـع يعيش في حالـة مـن التوازن والاستقرار، حيث كانت الممارسات وإلقيم في حالة من الاتفاق هن والانسجام، لكن جاء التغير الاجتمـاعي بممارسـات ونظم وظروف جديدة جعلت من القديم ونظمـه أموراً غير صالحة، أي أن التغير قـ أدي إلي تفكك التنظيم القديم. وطبقاً لهذا المدخل فإن قواعد وممارسـات

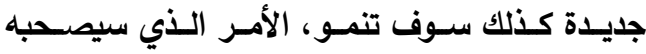

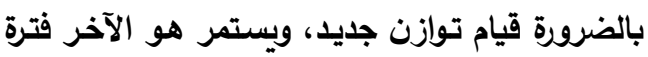
من الزمن إلي أن تأتي دورة جديدة من التغير . ويمكن القول أن المـزاعم التـي يعتمــ عليها مـذل

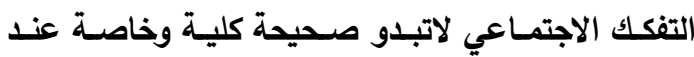

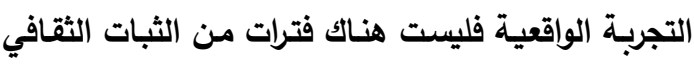
الكامل تنفصل بعضها عن بعض عن طريق دورات التغير
من أجل إثباع الحاجات العامـة والاجتماعية مثل: 1توفير السلـع والخدمات الأساسية للشعب. 2- رعايـة ودعم التعليم الإلزامي والجامعي ورعاية البحث العلمي. 3-توفير الحد الأدنى من المستلزمات وإلخدمات الصحية والجية والطبية والبيطريـة. 4-توفير ودعم المواصـلات وإلنقل لربط أجزاء الاقتصاد. 5-رعاية الثباب بما لا يؤدي إلي ولي زيـادة عدد العاطلين من البطالة. 6-حماية البيئة. 7 -

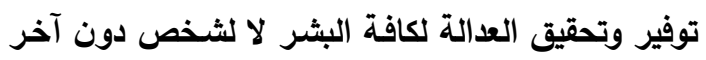
ولا لطبقة دون الأخرى بـلا تمييز. 8-تحقيق الضمان الاجتمـاعي ضد العجز والثيخوخة والمرض لكافة أفراد

$$
\text { الثعب (أمل حسانين، 2010، ص صن ص: 10:9). }
$$

ويعـرف الــليمي (2009، ص:38) الخـــ مــات

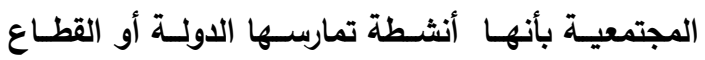
الخـاص لتـوفير منـافع بيئيـة وتقنيـة للإنسـان، والتـي تساهم في ديمومة عطاءه ورفع كفاءة أداءه، من خلال توفير مستلزمات الحياة الأساسية التي تحقق الصحة

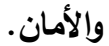

وتعرفها أمل حسـانين (2010، ص: 10) بأنها كل الجهود والخدمات والبرامج المنظمـة الحكوميـة والأهلية

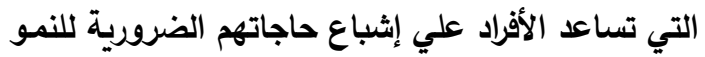
والتفاعل الإيجـابي معـاً فـي نطـاق الـنظم الاجتماعيـة القائمة لتحقيق أقصي تكيف ممكن مع البيئة الاجتماعية

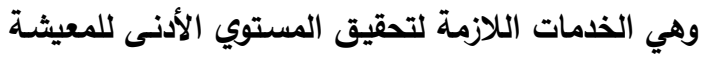

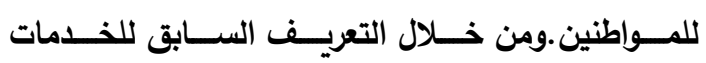
المجتمعية نجد أنها تسعي إلي تحقيق هدف أساسي وهو إثباع احتياجات الأسرة وتحسين مستوي معيشتها مهما اختلفـت الجهات المسـئولة عـن تقـديم تلـك الخـدمات المجتمعية سواء الحكومة أو الأهالي. وتضم المشكلات المئل

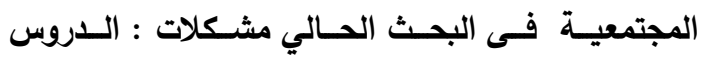

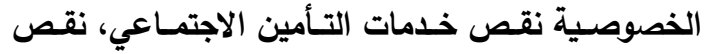
الخدمات التعليميـة، نقص خـمات النقـل والاتصـالات، نقص الأمس، نقص الخدمات الترفيهية، نقص المياه والصرف الصحي ونقص الكهرباء وإنتشار القمامة. 


\section{Social problems of rural women in some villages of Menoufia governorate}

ينتهك المعايير بل هو غير قادر علي تعلم هذه المعايير

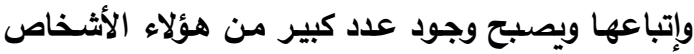
في المجتمع مشكلة اجتماعية. ويــــكر الذـــولى (2007، ص: 30) أن التفكـــك الاجتماعي عادة ما يؤدي إلي انحراف شخصي حيث أن

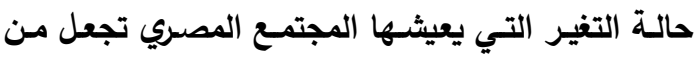

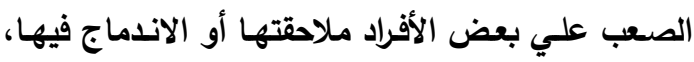

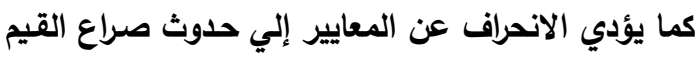
وإلتي يعاني منها بعض أفراد المجتمع، بجانب أنه يعكس إلمراف

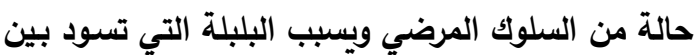
أفراد المجتمع وعدم شعورهم بالاستقرار. 3- المدخل الوظيفي : يذهب المـذخل الوظيفي إلـي أن المجتمع كبناء كلي يتكون من مجموعة من الأجزاء

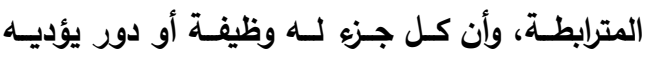

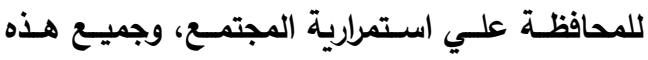

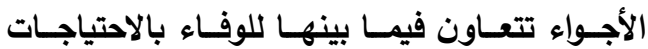

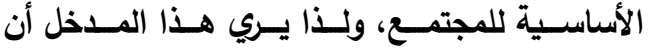
المجتمع في ظل الظروف المثالية يميل إلـي التوازن

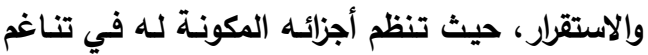
من أجل تحقيق الاستقرار.

ويري أنصار المدخل الوظيفي أن هناك عدة أسباب

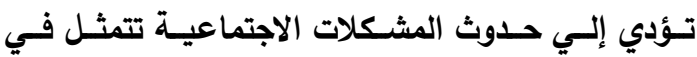

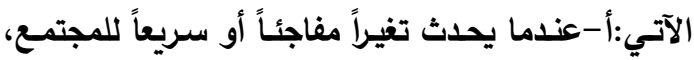
فإن حالة المجتمع تفقد التوازن لأن تنظيمات المجتمع لم يتح لها الوقت الكافي لتتجنب هذا التغير بصورة ملائمسة وبالتالي يصاب المجتمع بالاضطراب أو ما يسمي بالخلل الوظيفي.ب-قد تظهر المشكلات الاجتماعية بثكل جلي

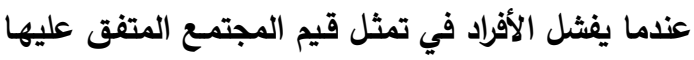

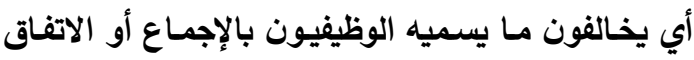

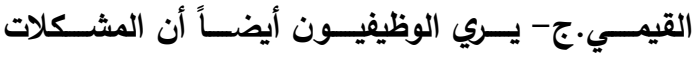
الاجتماعية يمكن أن تنتج عن الأداء الوظيفي الزائد عن

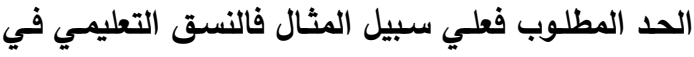
المجتمع قد يخرج أفراداً في أحد المجالات بما يزيل عن فئن

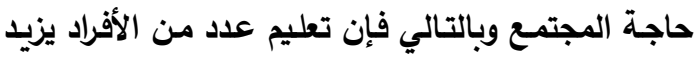

لأن التغير والتفكك وإعـادة التنظيم ظواهر مستمرة بـلا توقف، إلا أنه من المفيد أحياناً في فهم مشكلة معينة أن نرجع إلي فترة سابقة تكون الظروف فيها ثابتة نسبياً، ويشترط أن يكون الموقف الحالي قد تطور عنها مباشرة. ويـــكر الخــولى (1999، ص: 27) أن التغيـرات الكبيرة التي شهدها المجتمع المصري في السنوات الأخيرة

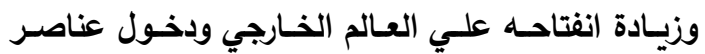
ثقافية جديدة أدت الي قلقة القواعد الاجتماعية خاصـة

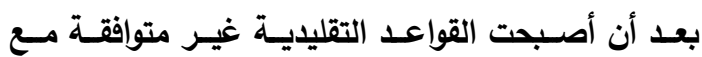
التغيرات المعاصرة، وبذلك حدث صراع بين الجماعات المرحبة بالتغيير والجماعات التقليدية مما أدي إلىي تفكك المكاص في العلاقـات الاجتماعيـة داخلـل المجتمـع حتـي وصـل التفكك إلي الأسرة نفسها.

2- مدخل الانحراف الثخصي : يركز مدخل الانحراف

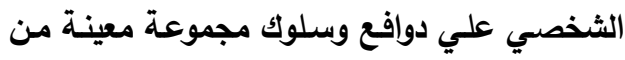
الناس تقع عليهم مسئولية إحداث المشكلة وعلي

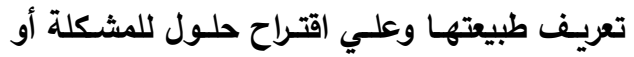
معارضتها إن هؤلاء الناس يعتبرون منحرفين حيث يـرتبط انحرافهم بطرق معينـة وعديــة بالمشـاكل

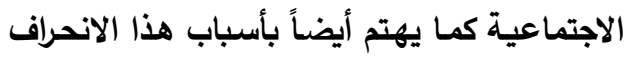
الثخصي والكيفية التي من خلالها تحدث المشاكل الاجتماعية.

ومن أسباب الانحراف الثخصي: أ-الفشل في متابعة المعايير: يحدث الانحراف الثخصي من خلال تعلم أفراد المجتمع للمعايير والقواعد السائدة في مجتمعهم حيث لا يستطيع بعض أفراد المجتمـع استيعاب وتعلم المعايير

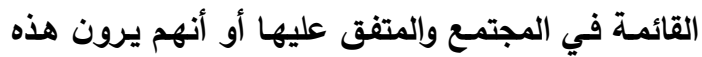
المعايير غير صالحة ومقيدة لطموحاتهم ونثاطهم في فئي

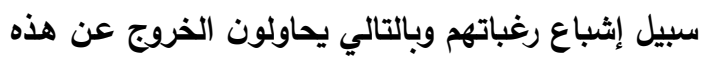

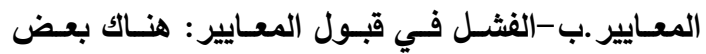
الأثــخاص لا يســطيعون إتبــاع المعـايير المقبولــة

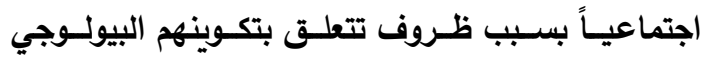

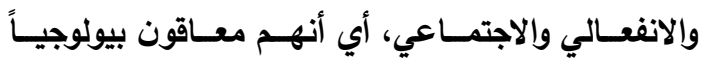
وانفعاليـاً واجتماعياً، ولههذا فبإن المعوق الاجتمـاعي لا لا 
الاراسات السابقة

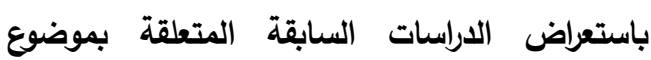
الاراسة الحالية والتي أمكن الإطلاع عليها، تم تصنيفها

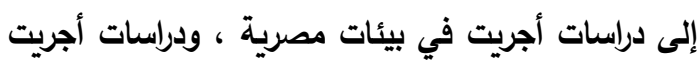

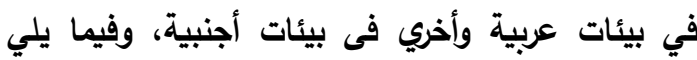

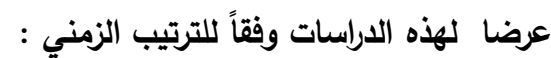
1-دراسات أجريت فى بيئات مصرية : سونيا نصرت

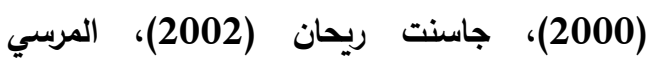

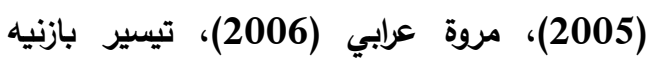

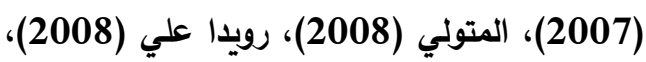
شرين محمد (2008)، ديكو (2008)، (2008)، هدي هليل

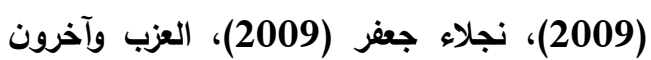
(2010)، أميرة عبدالعال (2011)، نجلاء جمغ (2012)، أمل الثافعي

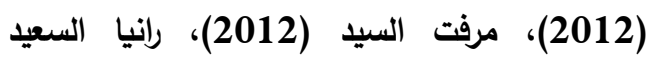

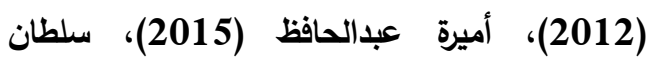
وآخرون (2015)، مشعل (2016)، تحية أبو

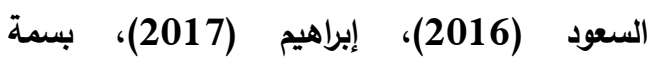
إسماعيل(2017)، شيرين دعدور (2017)، (2018)، آية (2017) ريحان (2018)، مي الرفاعي (2018)، (2018)، علي (2018) (2018)، محمود (2019).

2-دراسات أجريت فى بيئات عربية : بدرية العتيبي

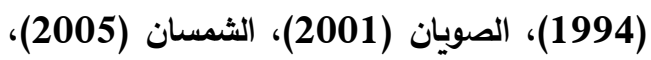
"نادر" مركز التغذية والتنمية الريفية (2006)، (2007)، السبعاوي (2007)، نورة وآخرون (2013)، (2013)، لقاء العابدي (2014)، انتصار خليل (2016)، نورة (خرون (2007)، .(2017)

3-دراسات أجريت فى بيئات أجنبية : Duxbury and others (1994) ،Hampton and Gelles (1994) ،Nicholas, wolfinger (2003) ،neshat, doost, ziagra (2008) ، Talbot (2011) .

رؤية تحليلية للاراسات السابقة 1-بالنسبة للمشكلات الأسرية : تبين من الدراسات التي تناولت المشكلات الأسرية مثل الصويان (2001)،
عن حاجـة المجتمع يعد خلـلاً وظيفياً في أداء النستق التعليمي لاوره في المجتمع. وبثـكل عـام فبإن المـدخل الـوظيفي يـري أن ظهور

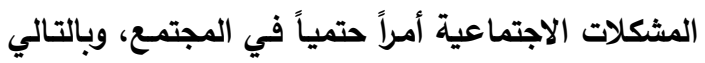

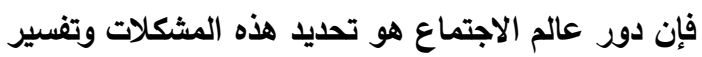
سبب ظهورها وإلنتائج المترتبة علي وجودها.

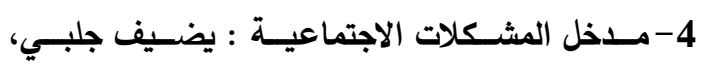
وآخرون (1999، ص ص: 13:11) نقلاً عن فولر

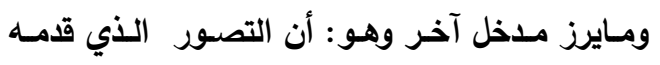

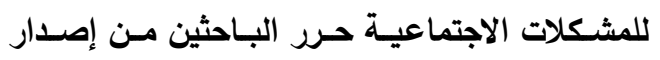

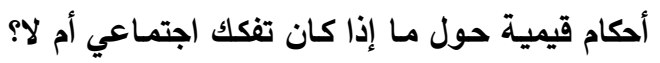

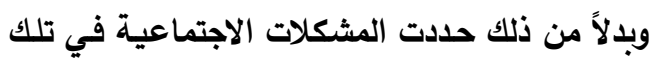

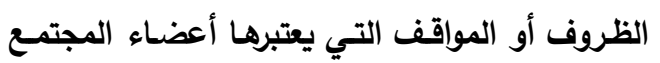

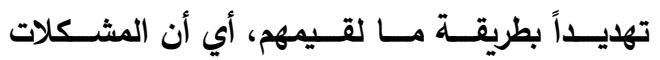
الاجتماعيـة هي مـا يظن النـاس أنها كذلك، ولكي الكي الكئي تكون هناك مشكلة اجتماعية ينبغي توافر شرطان. أولاً: ضرورة وجود ظرف موضوعي بالحجم والمقدار

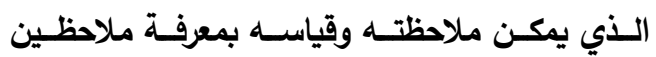

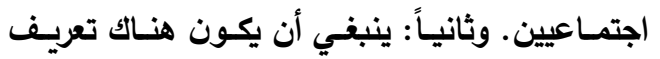

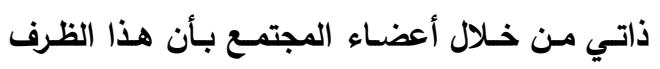
الموضوعي يعد بمثابة مثكلة.

ومهمـا كانت المثكلة الاجتماعية قادرة علي تهريد ظرف موضوعي أياً كان، فإنها لا تشكل مشكلة اجتماعية الاجماعة فادرة علي تهايل

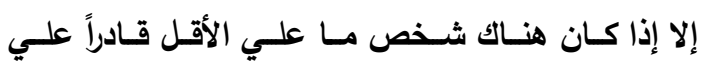

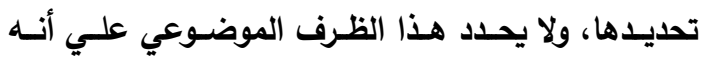

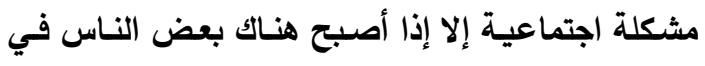

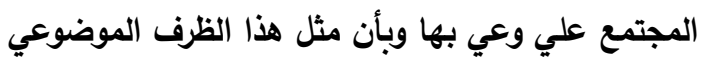
الأي أصبح يهاد قيمهم، وفي نفس الوقت فإن المشكلات

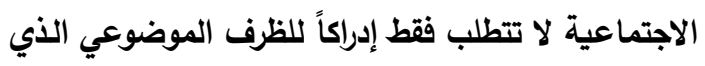

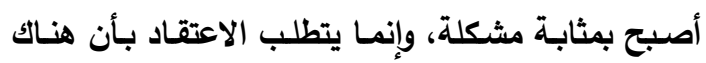
شيئاً ما يمكن عمله تجاه هذا الظرف الموضوعي. ويركز البحث الحسالي علي المداخل الأربعة السـابقة في دراسة المشكلات الاجتماعية . 
المـرأة وإهمـال الأولاد والتقصير في العلاقـات والواجبـات

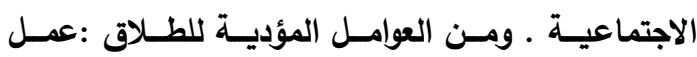

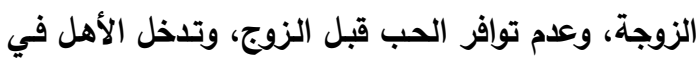

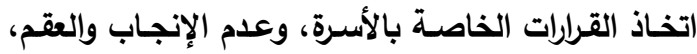

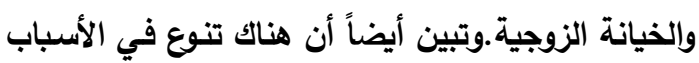

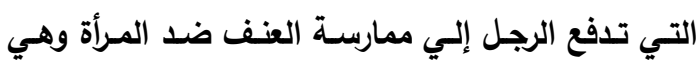

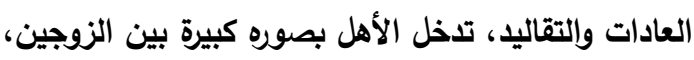
ضعف شخصية الزوج، ضغط العمل والفقر ـ وأتضح أيضاً

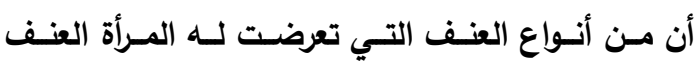

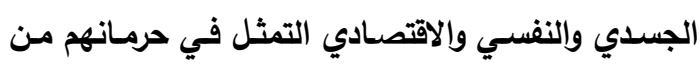
تلبيبة احتياجـاتهن واستيلاء الزوج علـي الدخل المـالي وعلم تحمل الزوج مسئولية الإنفاق علي الأولاد.

كما أثثتت بعض الدراسـات أن الحرمـان من التعليم،

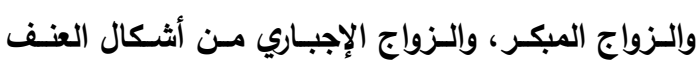

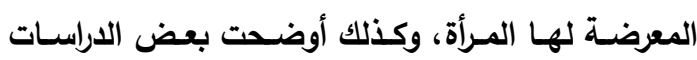
وجود علاقة بين كل من العمر ومستوي التعليم، الاتصـال الحضاري، استخدام الانترنت، والبطالة وبين الاغتراب.كما

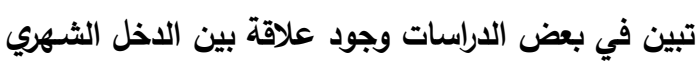

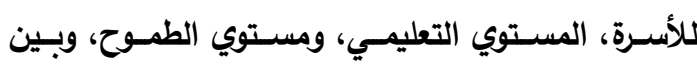
المعاناة من مشكلة وقت الفراغ.

2-بالنسبة للمشكلات الاقتصادية : تبين من الدراسـات

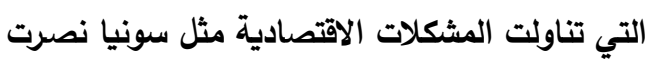

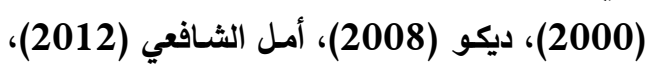
آيـة ريحـان (2018)، Talbot (2011) أن هنـاك علاقـة بين مستوي المعيثــة وكـل مـن المتغيـرات

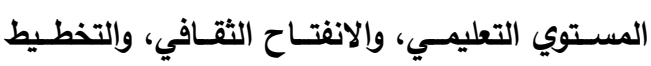

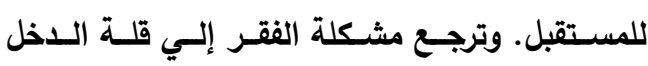

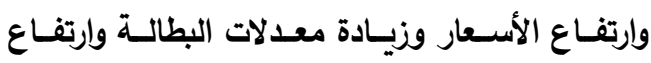
تكاليف المعيثـة، وأن أهـ الأسـاليب التـي يتخــها الفقراء للحد من فقرهم هي القيام بعمل إضافي وشراء الأبـاء

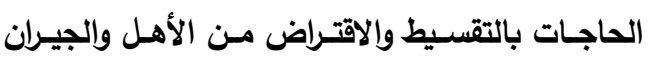

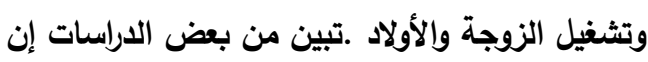

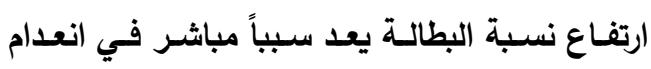

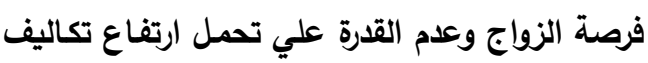

جاسـنت (2002)، الثمســان (2005)، السـبعاوى

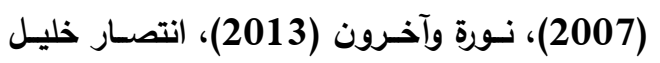

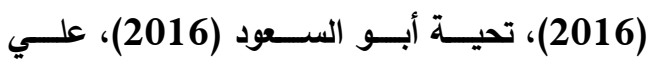

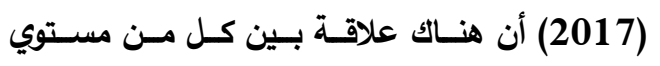

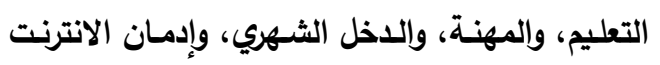

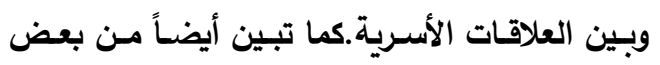

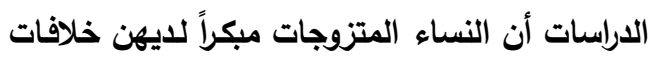

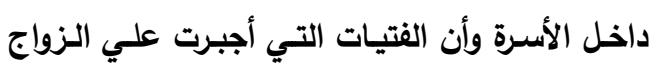

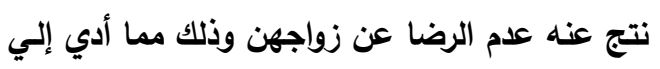

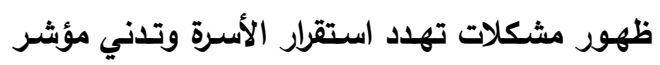

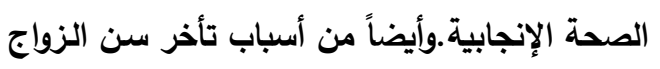

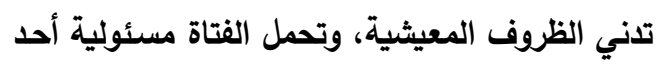

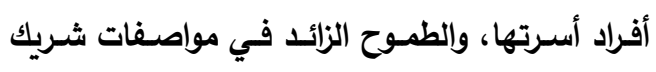

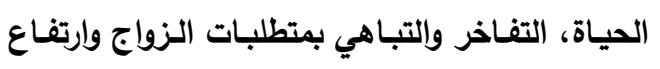
تكاليف الزواج والتمسك ببعض العادات والتقاليد. وأن تلك الدراسات اتبعت المنهج الوصفى التحليلي، ندرة الاراسـات الخاصسة بمثكلة الاسـتقلالية في الحيـاة

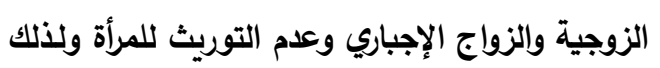
أجريت هذه الدراسة لمعرفة هذه المشكلات وأسبابها.

تبين من الدراسـات التالية (بلريـة العتيبي (1994)،

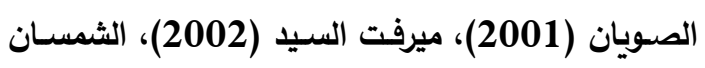

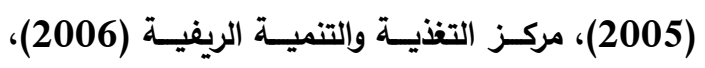

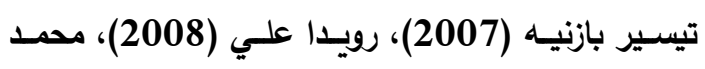

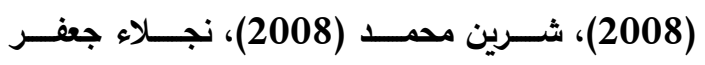

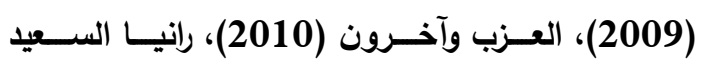

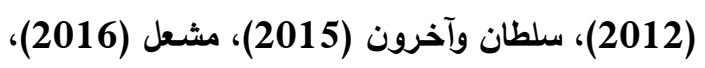

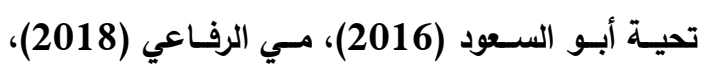
Nicholas, Wolfingcr ، (2003) Hampton and Gelles (1994) Neshat, Doost, Ziagra ،(2008)Duxbury and others((1994) أن المشاكل التي تتعرض لها المرأة نتيجة خروجها للعمل

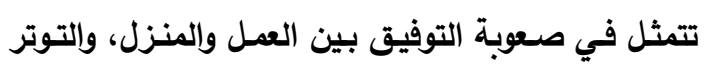
الناتج عن تعدد الأدوار، وارتفاع تكاليف المعيثـة نظراً للاحتياج للمـال، قلـة تفهم بعض الأزواج لطبيعة عمل والفل 
3-يسـهم كل متغير من المتغيرات المستقلة المدروسـة

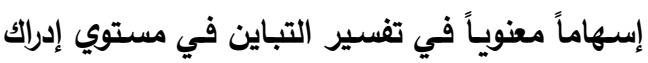

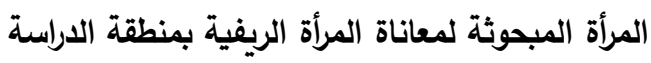

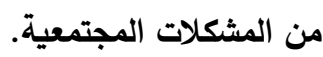

\section{الإجراءات البحثية \\ أولا : منطقة الدراسة}

أجريت هذه الدراسة في محافظة المنوفية، التي تقع التعاسه شمال العاصمة القاهرة في جنوب دلتا النيل، وعاصمتها

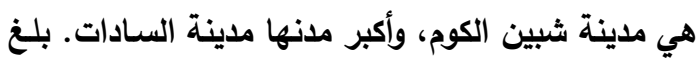
عـد سـكانها 4,469,679 نســة (الجهـاز المركـزي

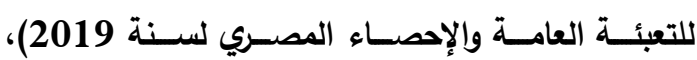
ومسـاحتها 2,543.03 كم 2. وتضم محافظة المنوفيـة بثكلٍ عام من 9 مراكز إدارية و 69 وحدة قروية تحتوي على 312 قرية و 961 كفراً ونجعاً . وتضم المراكز 10

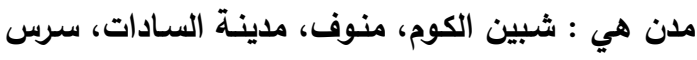

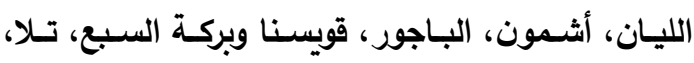

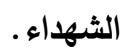

وتـم اختيـار أعلـي وأدنـي عشـر قـري فـي محافظـة المنوفية من ( دليل التنمية البثرية لمحافظة المنوفية 2015) وبنـاءً علـي ذلك تـم اختيـار أعلي وأدنسي قريـة ووقع الاختيار علي قريـة عرب الرمل من مركز قويسنا

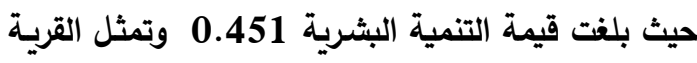
ذات المستوي التنموي الأعلي وتم أخذ 200 مفردة من قرية عرب الرمل ـ وأيضا وقع الاختيار علي قرية طمـلاي

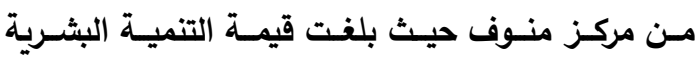

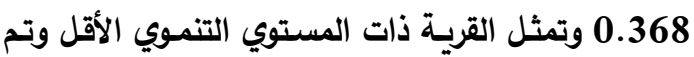

أخذ 200 مفردة من قرية طملاي.

ثانيًا: شــاملة الدراســة وطريقــة اختيــار العينـة البحثية

أ- شاملة الدراسة

تحددت شاملة البحث في ربات الأسر الريفية بقريتي

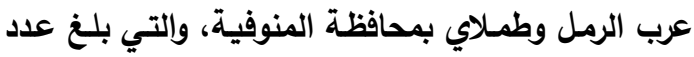

الـزواج وإنخفــاض الــلـل.وأن مسن أسـباب ارتفـاع

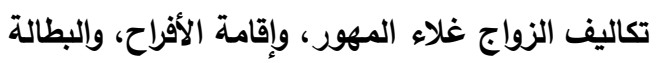
بين الثباب، وعدم القدرة علي توفير المسكن. كما تبين بعض الدراسات وجود علاقة بين الفقر والبطالة وبين المعاناة من تأخر سن الزواج. 3-بالنسبة للمشكلات المجتمعية: يتبين من الدراسـات

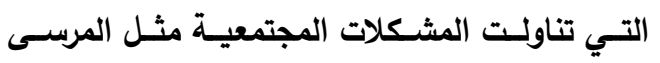

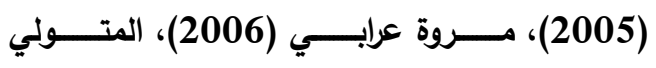

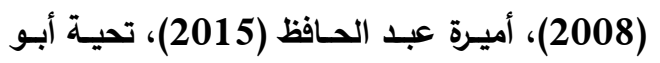
السعود (2016)، علي (2018)، محمود (2019) (2001) (2015)

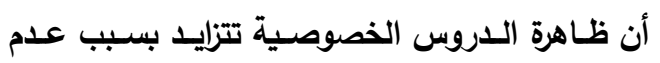

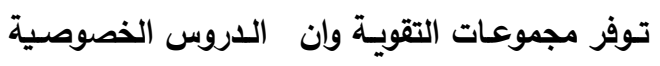
أصبحت وسيلة للآباء لإلقاء مسئولية تعليم وتربية

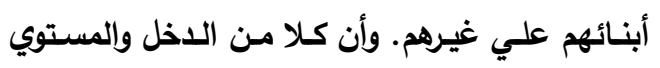

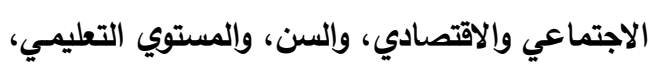

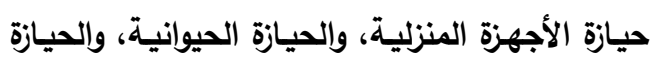
الزراعية ترتبط في كثير من الخدمات المجتمعية. استهافت بعض الدراسات تفعيل خطط التحسين بصورة واقعية داخل المدرسة ودراسة الاحتياجات الفعلية

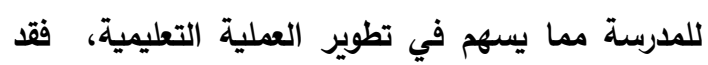

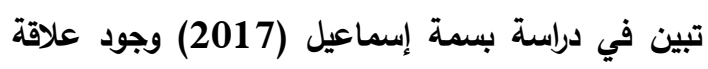
ارتباطية بين الحالة التعليمية، عمل المبحوثة، الاخل الثهري، وبين المعاناة من سوء الذدمات الصحية.

$$
\text { الفروض البحثية }
$$

1- يسهرم كل متغير من المتغيرات المستقلة المدروسـة

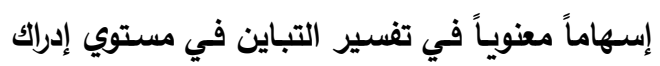

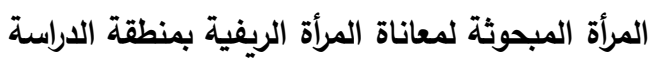

$$
\text { من المشكلات الأسرية. }
$$

2-يسهر كل متغير من المتغيرات المستقلة المدروسـة

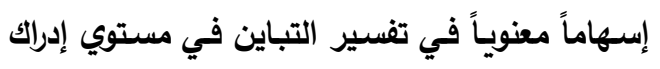
المرأة المبحوثة لمعاناة المرأة الريفية بمنطقة الدارية فئوية من المثكلات الاقتصادية 
تصبية المعايئة $=\frac{N}{\mathrm{n}}=\frac{4085}{200}=20$

وأيضا تم اختيار أول بيت عشوائيا ، ثم ترك

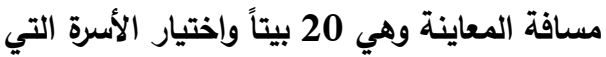

تليهـا وهكـذا حتــي تـم الحصـول علـي العينـة

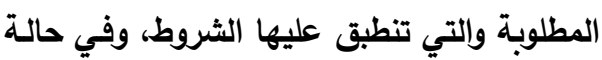

عدم توفر الثروط في الأسرة التي تم اختيارهـا

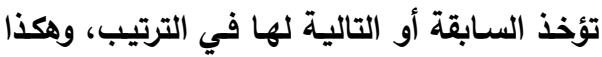

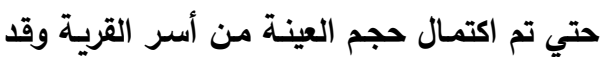

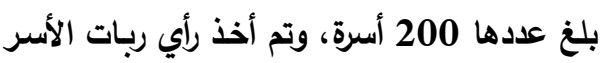
بقرية طملاي علي استمارة الاستبان.

ثالثًا: أسلوب جمع البيانات وفقَّا لطبيعـة وأهـداف الدراســة استخدم الإسـتبيان

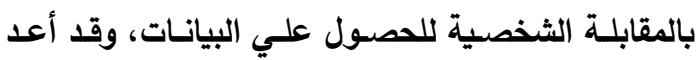
متسقاً مع الأهداف وذلك لتحقيق أهداف الدراسة. كمـا تم تخصيص استمارة لاستطلاع رأي المبحوثات في عداد من الهن الموضـوعات المتعلقـة بالمشــاكل المختلفــة التـي تواجـهـ المرأة الريفيـة. وقد مـرت الاستمارات بعدة مراحل بداءاً

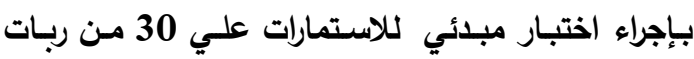
الاسرة الريفية بقريـة الماي، وتم استبعادهم من العينة، وتم تدقيق الاستمارات وإعدادها في صورتها النهائيـة

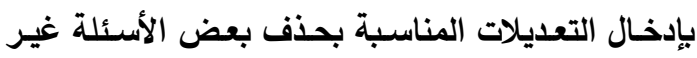
المناسبة وصياغة بعض العبارات، وقد استغرقت مدة جمـع البيانات أربعة أثهـر (أغسطس وسبتمبر وأكتوبر ونوفمبر) عام 2018 بالمقابلة الثخصية لربات الأسر

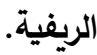

رابعاً: المتغيرات البحثية وكيفية قياسها

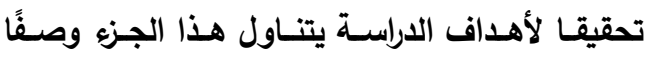
للمتغيـرات البحثيـة المسـتخدمة فـي الاراســة وكيفيـة قياسها.

القسم الأول: المتغيرات المستقلة أ- اشتملت الدراسـة علي ثمانية عشر متغيراً مستقلاً وفيما يلي تفاصيل القياس لكل منها:
الأسر في قريـة عرب الرمل 4898 أسرة (بيان السكان التقديري لعام 2016 مركز قويسنا مركز المعلومات ودعم (تخاذ القرار).

وبلغ عدد الأسر في قرية طملاي 4085 أسرة (بيان السـكان التقـــيري لعــام 2016 مركــز منــوف مركــز المعلومات ودعم اتخاذ القرار). ب- اختيار العينة البحثية

تم تحديد حجم العينة من خلال معادلة Yamane

$$
\text { وهي }
$$

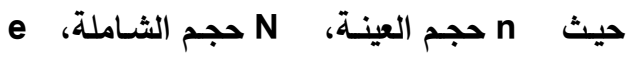
مستوي الاقة (العزبي، 2017).

$$
n=\frac{4898}{1+\left[4898(0.07)^{2}\right]}=196
$$

وتم زيـادة حجم العينـة إلي 200 أسرة لزيـادة تمثيل

نسبه المعاينة

$$
\text { تصنية المعايئة }=\frac{4898}{200}=25
$$

وتم اختيار أول بيت عشوائيا، ثم ترك مسافة المعاينة

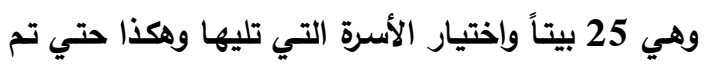
الحصــول علـي العينـة المطلوبـة والتــي تنطبـق عليهـا

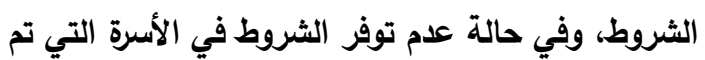

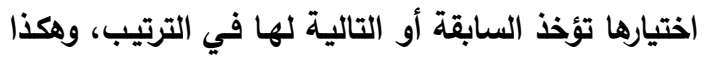

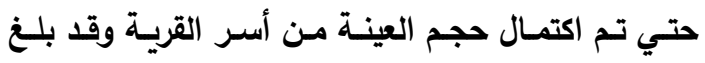

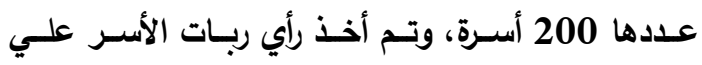
استمارة الاستبيان في قرية عرب الرمل.

$$
n=\frac{4085}{1+\left[4085(0.07)^{2}\right]}=195
$$

وتم زيـادة حجم العينـة إلـي 200 أسرة لزيـادة تمثيل المجتمع. 
الأوزان (1،2،3، (3) علي الترتيب.عدد الغرف: إذا كان المنزل يتكون من (غرفة، غرفتين، أكثر من غرفتين)

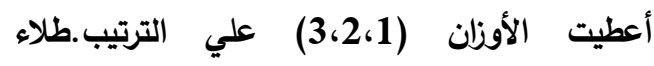

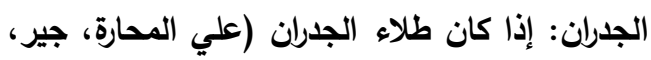

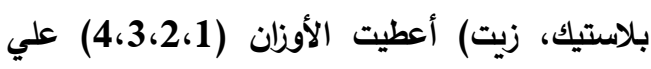

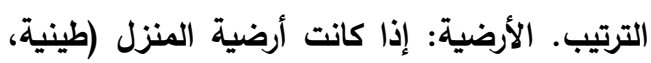

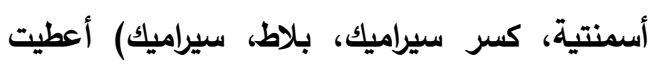

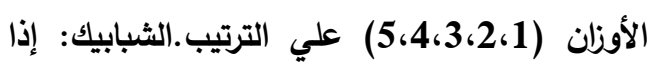
كانت معظم الثبابيك بالمنزل (شيش، زجاج، سلك، الكان،

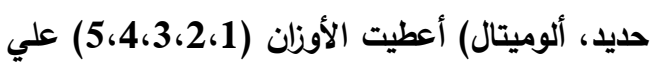

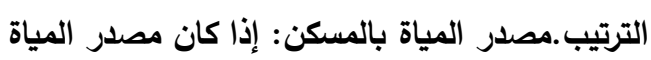

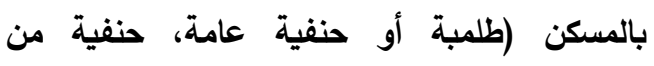
الثبكة، شبكة مياه نقية بالمنزل) أعطيت الأوزان

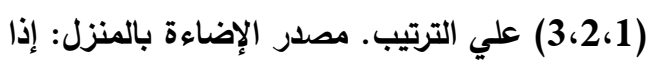

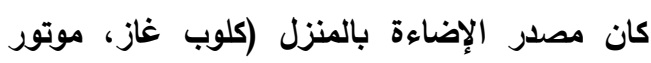
كهرباء، كهرباء من ان الثبكة) أعطيت الأوزان (الصرف (3،2، ) علي الترتيب.الصرف الصحي: إذا كان نوع الصناء

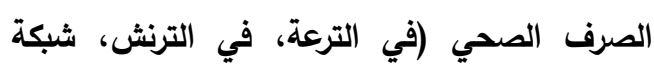

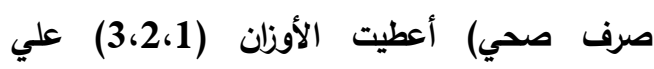
الترتيب. - المرحاض: إذا كان نوع المرحاض (بلدي، أفرنجي،

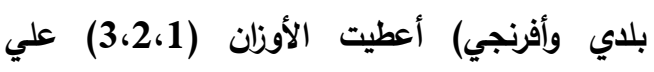
الترتيب. مكان الطهي: إذا مكان الطهي (في أي الأي

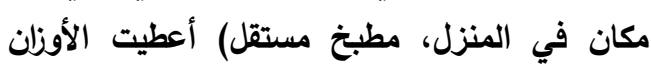
(2،1، (2) علي الترتيب.حظيرة الماشية: إذا كان مكانها (خارج المنزل، داخل المنزل، لا يوجد) أعطيت الأوزان (2،3،2، 1، علي الترتيب لوبجمع الارجات التي

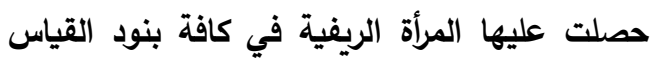

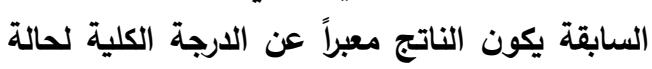
مسكن المبحوثة.

(ب) حيازة الأجهزة المنزليـة : ويقصد بها مـا تحوزه الأسرة المبحوثـة من أجهزة منزليـة وتم إعطاء هـا

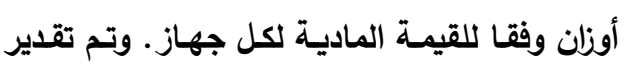
الأوزان علي النحو التالي: أعطيت درجة واحدة لكل
1- السن: ويقصد به سن المرأة الريفية من وقت الميلاد حتي تاريخ جمع البيانات ويعبر عنه بقيمة رقمية. 2- الحالة الاجتماعية: ويقصد بـه حالة المرأة الريفية

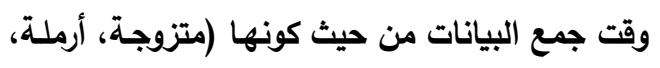

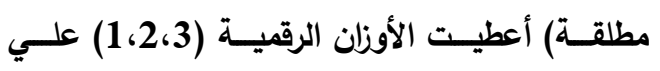
الترتيب. 3- الحالة التعليمية: ويقصد بها المستوي التعليمي للفرد

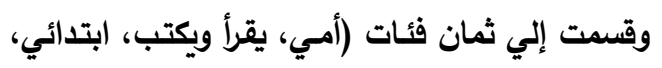

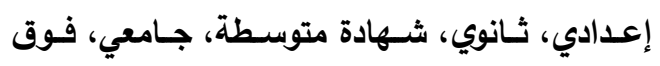

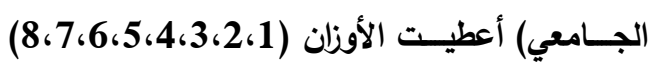
علي الترتيب. 4- الحالة العملية: ويقصد بها عمل المراة وقسمت إلي العي

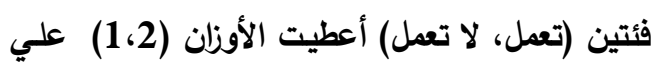
الترتيب. 5- الدخل: ويقصد بها إجمالي الإيرادات النقدية للأسرة

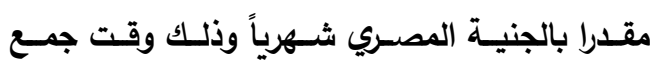
البيانات.

6-مستوي المعيشة: ويقصد بها حالة مسكن المبحوثة من حيث: من مئري (أ) حيازة المسكن - نوع المنزل: إذا كان مسكن الأسرة (ملك خاص،

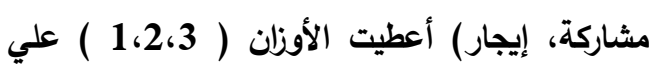

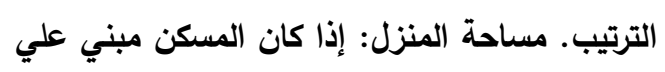

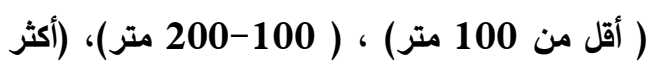

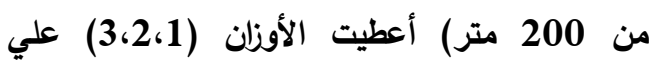
الترتيب. - ع عدد الأدوار: إذا كان المنزل مكون من (دور واحد،

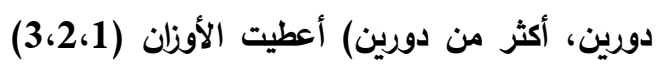

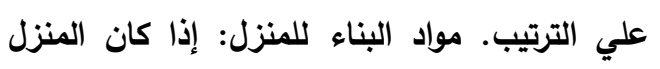

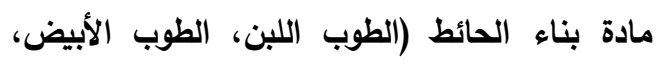

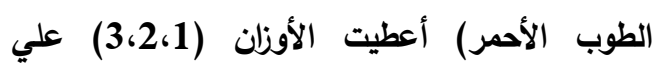
الترتيب. - سقف المنزل: إذا كان نوع سقف المنزل (معرش،

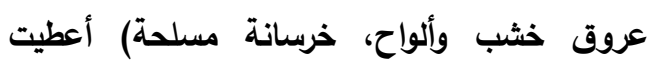


ري (2)، ماكينــة دراس (2)، عزاقــة (1)، محسـراث

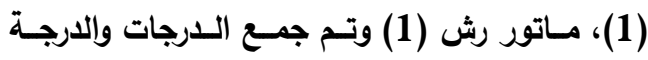

الكلية تعبر عن حيازة الآلآت الزراعية.

10- الانفتاح الثقافي : ويقصد بها مدي مواظبة الات الزئه المرأة

الريفية المبحوثة علي مشاهدة التليفزيون، مشاهدة

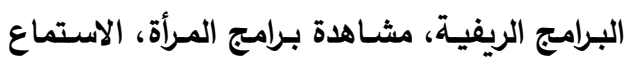

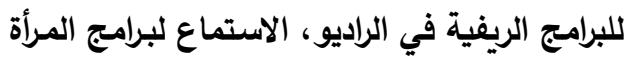

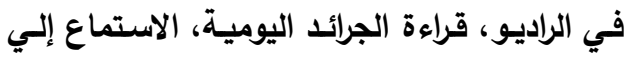

أحد يقرأ الجرائد، حضور الندوات الثقافية، حضور

الندوات السياسية، حضور الندوات الدينية، الدخول

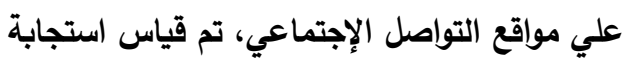
المرأة المبحوثة علي مقياس رباعي (كثيرًا ، أحيانًا،

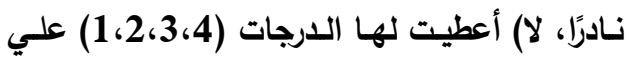

الترتيب ثم حسبت درجة لكل مبحوثـة من خـلال

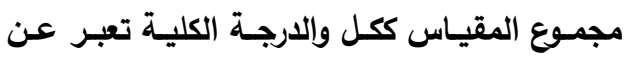
الانفتاح الثقافي.

11- الانفتاح الجغرافي : ويقصد بـه مدي تردد المـرأة

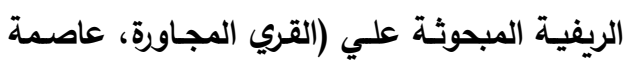

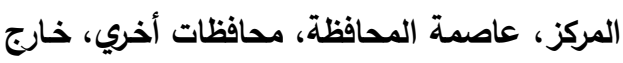

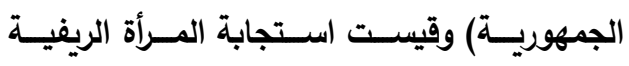

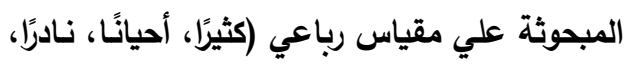

لا) أعطيت لها الارجات (4،3،2، 1، 1) علي الترتيب

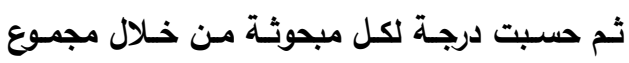

المقيساس ككل والدرجـة الكلية تعبر عن الانفتـاح

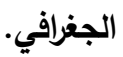

12- المشاركة الاجتماعية غير الرسمية : ويقصد بها

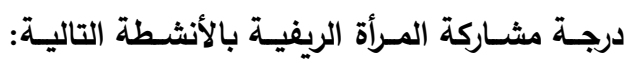

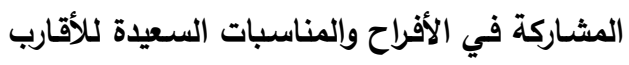

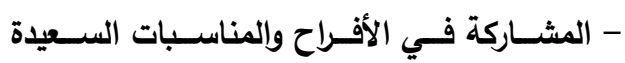

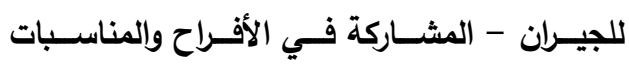

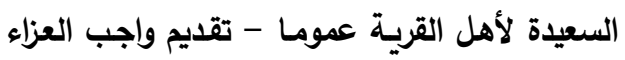

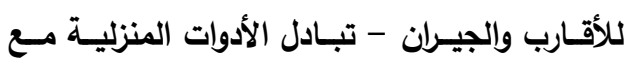

الجيران من نساء القرية - تبادل الزيارات مع الأهل

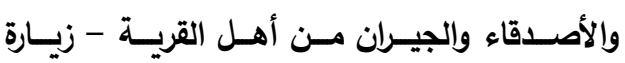

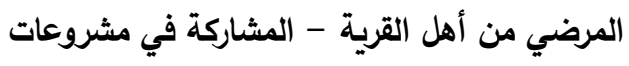

جهاز مـن الأجهزة التاليـة (شعلة، شفاط، راديو،

مكواة، تسجيل، دش). وأعطيت درجتان لكل جهاز

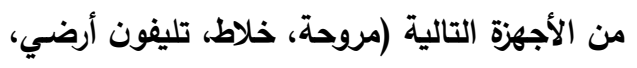
موبايل، فرن غاز، ماكينة خياطة). وأعطيت ثلاث

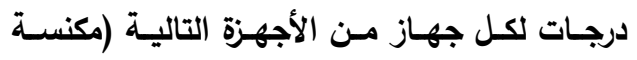

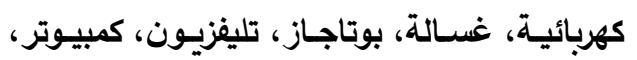

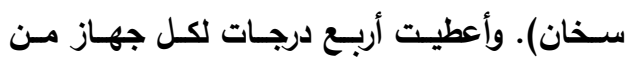

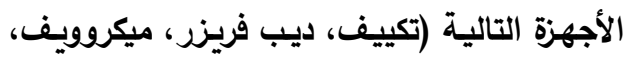

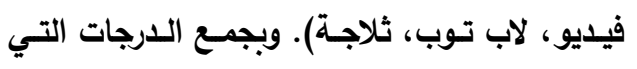

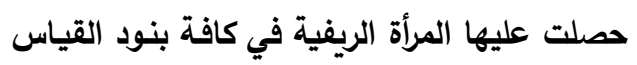
السابقة يكون الناتج معبراً عن الدرجة الكلية لحيازة أسـرتها علـي الأجهـزة المنزليـة.وتم عمـل معسايرة

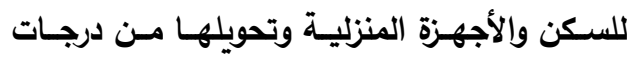
معيارية إلي درجات تائية حتي يكون هناك مقياس ثابت لهما من خلال المعادلة التالية :

Z( Standard Score ) =X-M /S

حيث X هي قيمة المفردة، وM المتوسط الحسابي، و Sي الانحراف المعياري للمتغير المراد معايرة قيمته.

(علام، 1985).

\section{$\mathrm{T}-$ Score $=10 \mathrm{z}+50$}

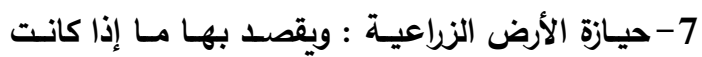

الأسرة لديها حيازة زراعية (ملك، مشاركة، إيجار، لا)

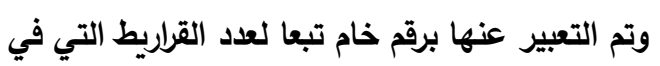

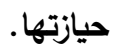

8- حيازة الحيوانات الزراعية والطيور: ويقصد بها مـا إذا كانت الأسـرة المبحوثة تربي حيوانـات زراعيـة أم لا

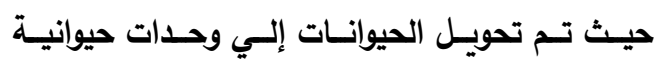

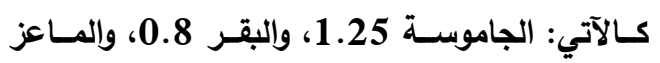

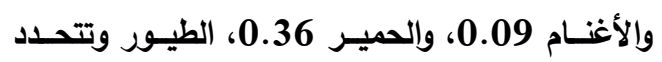
بعدد الطيور التـي تحوزهـا المرأة المبحوثـة (بـالي، والطئ

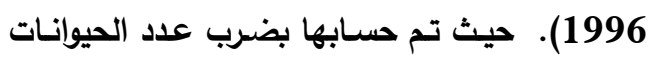
في الوحدة الحيوانية الخاصة بها.

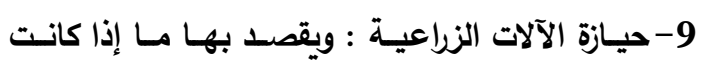

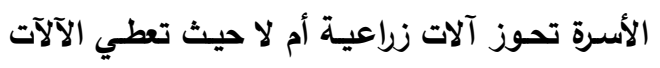

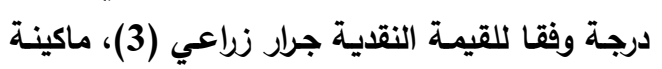




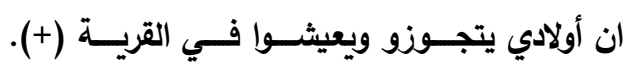

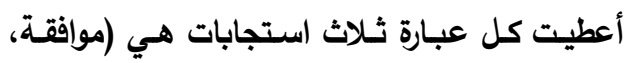
محايده، غير موافقة) أعطيت الدرجات (2،3، 1، 1، علي الترتيب إذا كانت العبارة إيجابية، يشار إليهات اليهات

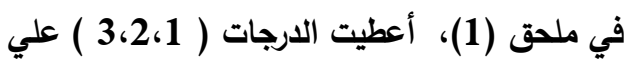

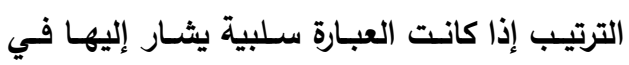

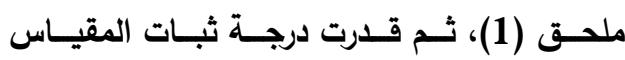

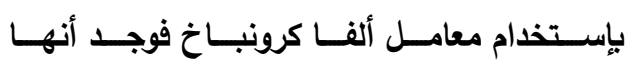
(0.719)، وهي قيمة مقبولية إحصائياً وتلال علي ثبات المقيـاس، ويمثل مجمـوع هذه الاستجابات الارجة الكلية للرضا عن الحياة بالقرية.

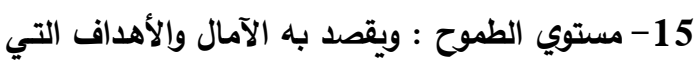

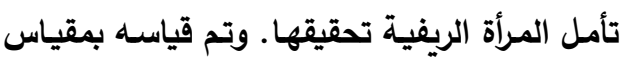
مكون من ثلاثة عشر عبارة هي: الواحد لو جاتله

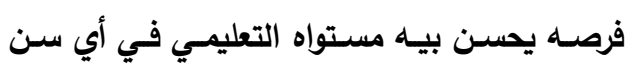
ميسيبهاش (+)، لو فيه فرصة عمل كويسة فيها

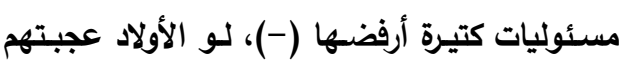
حاجة جديدة في اعلانات التليفزيون أشتريها علي طول (+)، كفايـة البنت تقرا وتكتب لأن مسيرها

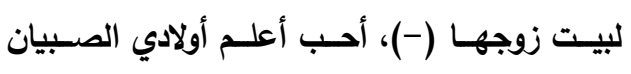

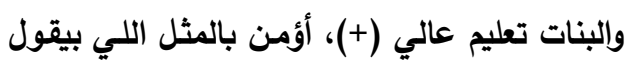

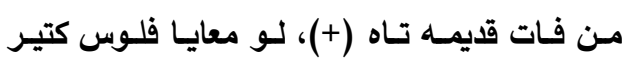

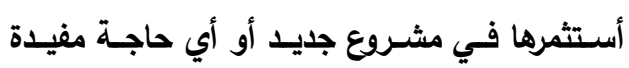
(+)، لو فثلت في أي حاجة المفروض مـا أكررها

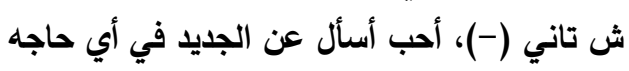

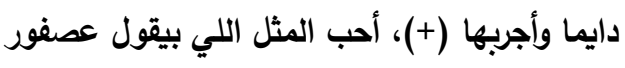

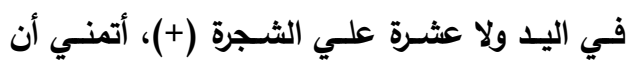

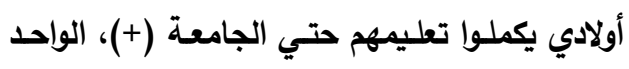

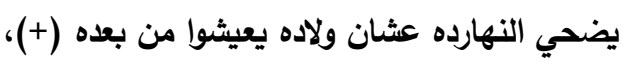

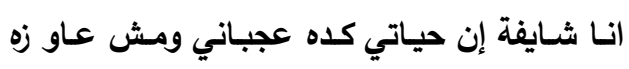
أغير فيها (-).وأعطيت كل عبارة ثلاث استجابات

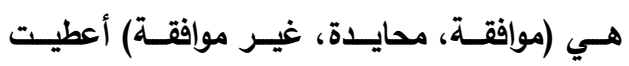
الدرجات (2،2، 1، 1) علي الترتيب إذا كانت العبارة

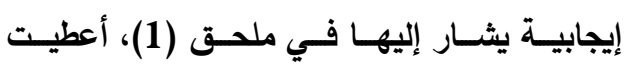
الدرجات (1،2،3) علي الترتيب إذا كانت العبارة
الجهـود الذاتيـة بالقريـة وقيسـت اسـتجابة المـرأة الريفية البحوثة علي مقياس ( كثيرًا، أحيانًا، نادرًا،

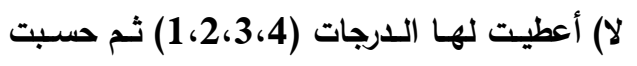
درجة لكل مبحوثة من خلال مجموع المقياس ككل

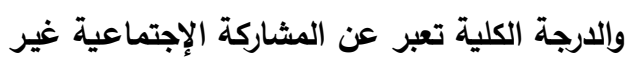
الرسمية. 13- قيادة الرأي : ويقصد بها درجة أخذ أي المرأة في

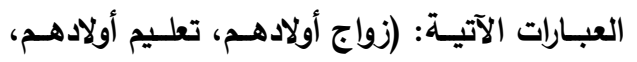

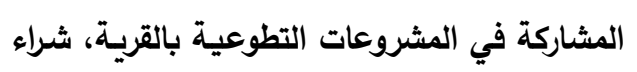

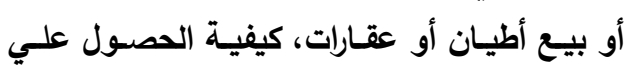

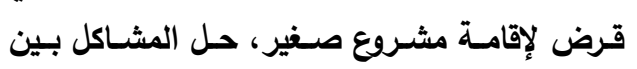

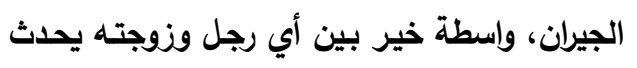

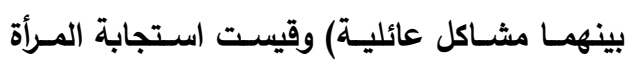
الريفية المبحوثة علي مقياس(كثيرًا، أحيانًا، نادرًا،

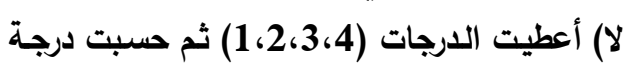

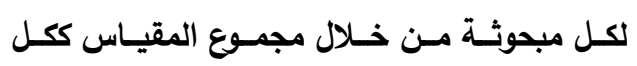
والارجة الكلية تعبر عن قيادة الرأي.

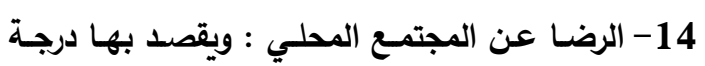

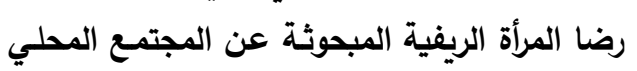
وتم قياسـه بمقيساس مكون خمسـة عشـر عبـارة اتجاهية (ايجابية وسلبية) هي: القريـة هي أحسن فئسن مكان بالنسبة لي (++)، يحزنتي سماع أو رؤية أي الي

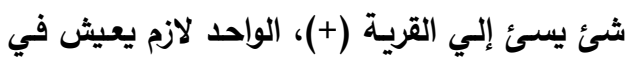

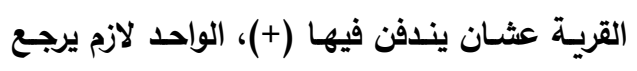
لبلده مهما طال الزمن (+)، أرحب بمغادرة القريـة

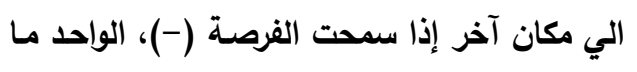

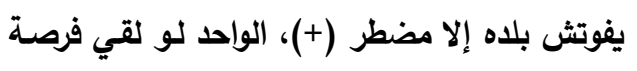

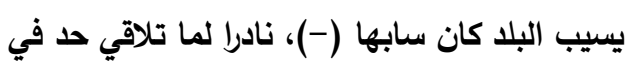

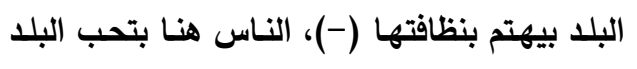
ومبتسـيبهاش (+)، مـن الصـعب ان أجــ مكسان

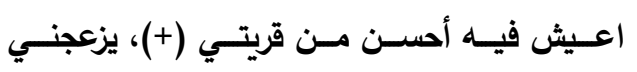

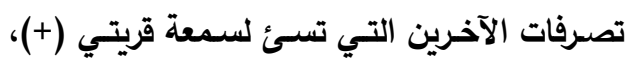

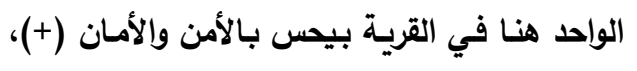

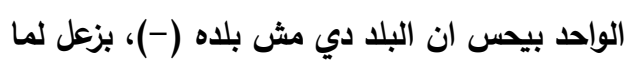

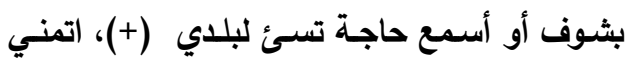


يتنافى مـع وضع الرجل الثرقي (-)، علي الزوج

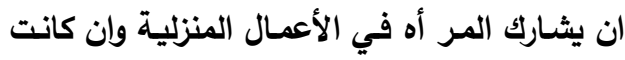

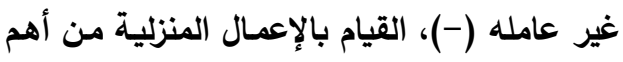

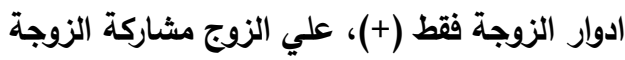

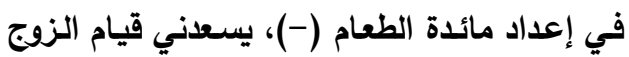
بغسيل الأطباق إذا سـمح وقته بـألك (-)، شـراء

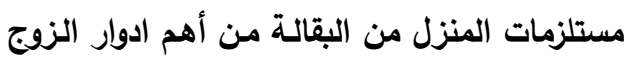

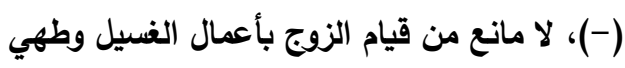

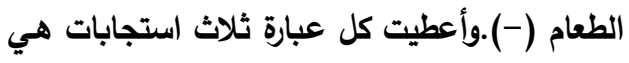
(موافقة، محايدة، غير موافقة)، أعطيت الدرجات (1،2،3) علـي الترتيب إذا كانـت العبارة إيجابيـة

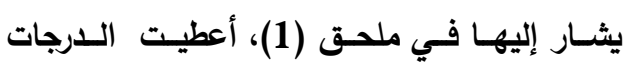
(3،2،1) (3، علـي الترتيب إذا كانـت العبـارة سـلبية

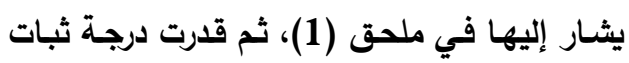
المقياس باستخدام معامل ألفا كرونباخ فوجد أنها (0.630)، وهي قيمة مقبولة إحصائياُ وتلدل علي

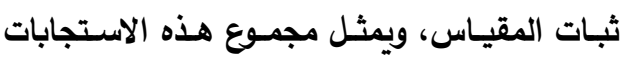
الارجة الكلية للقوامة والمسئولية الاجتماعية.

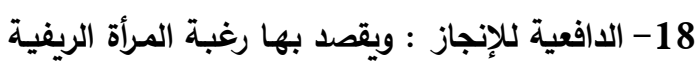
في القيام بعمل جيد والنجاح في ذلك العمل. وتم

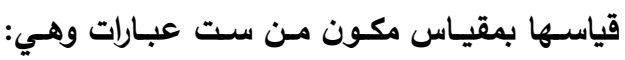

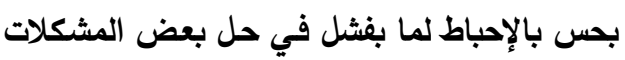

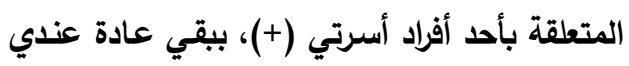

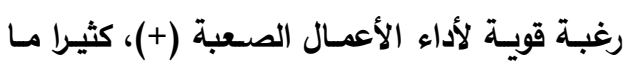

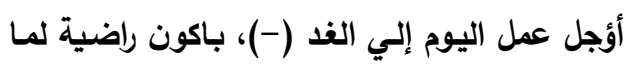

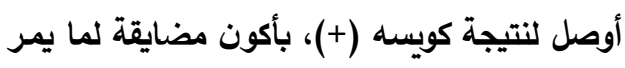
الوقت دون ان احقق عملا نافعا (+)، بفضل أبذل كونل

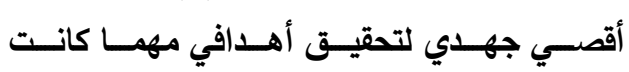
الصعوبات التي تواجهني (+). أعطيت كل عبارة ثُلاث استجابات (موافقـة، محايدة، غيـر موافقـة) وأعطيت الارجات (2،3،2، 1، علي الترتيب إذا كانت

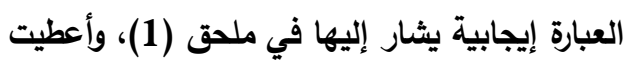
الدرجات (1،2،2، (3) علي الترتيب إذا كانت العبارة

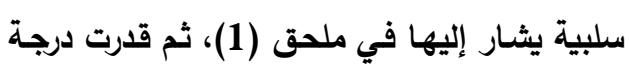

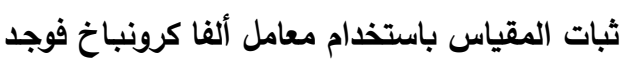

سلبية يثار إليها في ملحق (1)، ثم قدرت درجة ثبات المقياس باستخدام معامل ألفا كرونباخ فوجد أنها (0.619)، وهي قيمة مقبولية إحصائياً وتلال

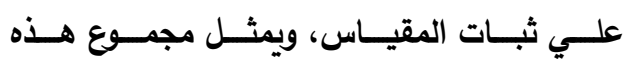
الاستجابات الارجة الكلية عن مستوي الطموح. 16- التخطـيط للمستقبل : ويقصـــ بهـا رؤيسـة المـرأة

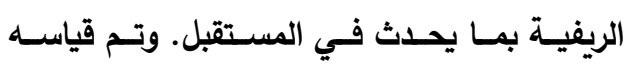
بمقياس مكون من سبعة عبارات هي: التخطيط في

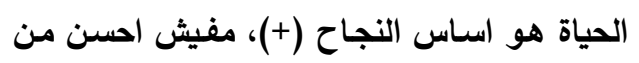

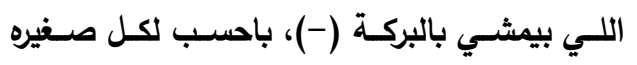

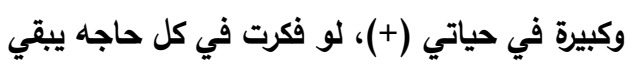

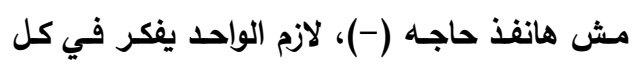

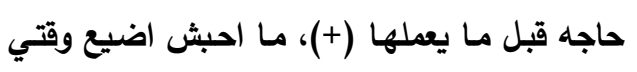

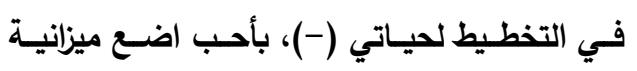
للبيت عشان نمشي عليها (+).وأعطيت كل عبارة

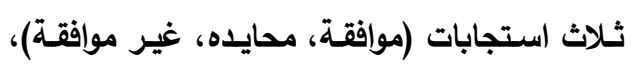

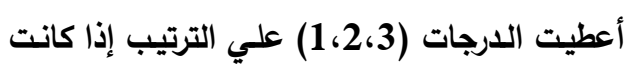

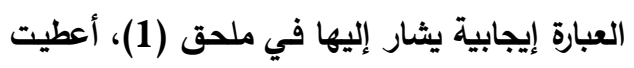
الدرجات (1،2،3) علي الترتيب إذا كانت العبارة

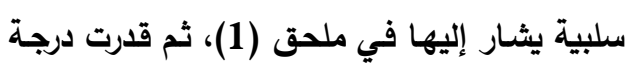

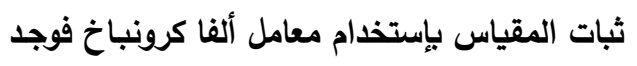
أنها (0.716)، وهي قيمة مقبولية إحصائياً وتدل

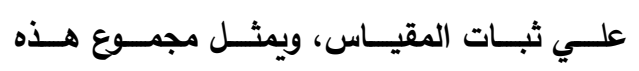
الاستجابات الارجة الكلية عن التخطيط للمستقبل.

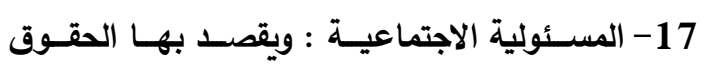
والواجبات التي تقوم بها المرأة الريفية. وتم قياسها بمقياس مكون من ثلاثة عثر عبارة وهي: للزوج

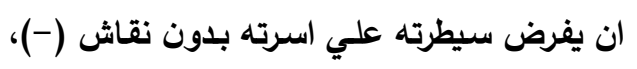

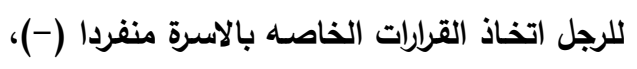

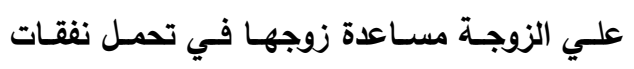
الأسـرة (+)، الزوجـة غيـر مكلفـه بالأنفــاق علـي

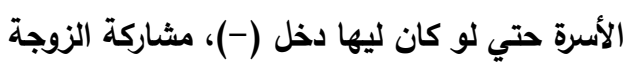

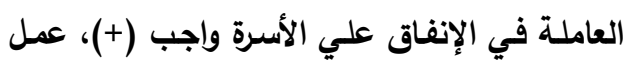
الزوجـة خـارج المنزل يلزم الززوج مشـاركتها في الإني الاعمال المنزلية (+)، قيام الزوج بالإعمال المنزلية 


\section{F. A. Salama, et al.,}

متوســطة، قليـــة، لا أعــــي)، وأخـــت الأوزان

خامسًا: أساليب التحليل الإحصائي المستخدمة بعد الانتهاء مـن جمـع البيانـات وتفريغها وتبويبها وجدولتها ، تم استخدام البرنامج الإحصائي (SPSS) في وتئي تحليل البيانـات، وإستخدام العرض الجدولي كـالتكرارات

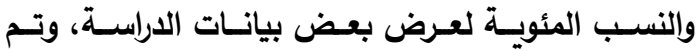

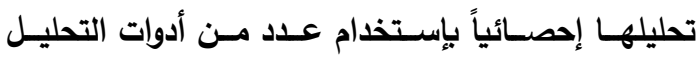

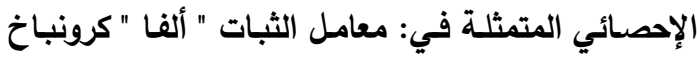
لتقدير درجـة ثبـات مقـاييس المتغيـرات متعددة البنـود،

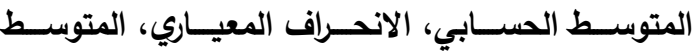
الحسـابي المـرجح، معامـل الإرتبـاط البسـيط (بيرسـون)،

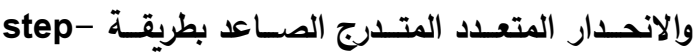
.wise

سادسًا: وصف خصائص عينة الدراسة 1- السن: يعرض جدول (1) توزيع أفراد العينة البحثية

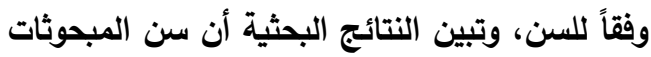

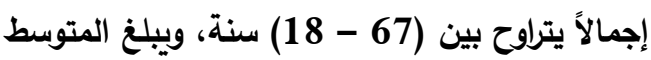
الحسابي للسن 40.77 درجة بإنحراف معياري قدره 9.06 درجة. ويتضح من بيانات الجدول أن

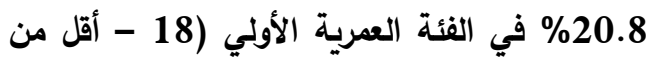
34 سن)، وأن 66.3\% في الفئة العمرية الثانية

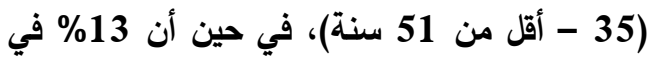
الفئة العمرية الثالثة (52 - 67 سنة). 2- الحالة الاجتماعية : يعرض جدول (1) توزيع أفراد

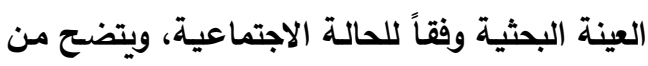
بيانـات الجدول أن 63.8\% مـن عينـة ربـات الأسر متزوجة، وأن 25.5\% من عينة ربات الأسر أرملة، وأن 10.8\% مطلقة.

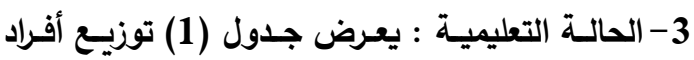

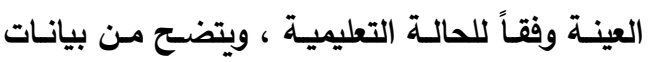

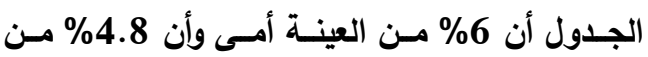

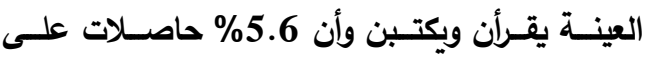

أنها (0.675)، وهي قيمة مقبولة إحصائياً وتدل

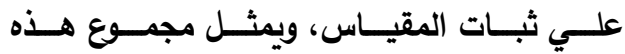
الاستجابات الارجة الكلية للدافعية للإنجاز. القسم الثانى: المتغيرات التابعة تتمثل في ثلاثة متغيرات تم قياسها علي النحو

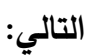
أولًا: المشكلات الأسرية : ويقصد بها مستوي إدراك المرأة المبحوثة لمعاناة المرأة الريفية من المشكلات

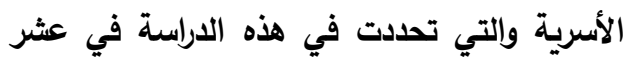
مشكلات فرعية وهم (ضعف العلاقات الأسرية،

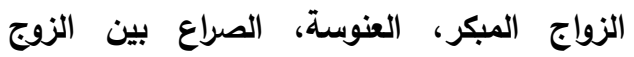
والزوجة، الميراث، الاستقلالية فى الحياة الزوجية، الزواج الإجباري، عمل المرأة (صراع الأدوار)، العنف ضد المرأة،والطلاق وتم قياسها بأربعة أوزان (كبيرة، متوسطة، قليلة، لا أعاني)، وأخذت الأوزان

ثانياً: المشكلات الإقتصادية : ويقصد بها مستوي إدراك المرأة المبحوثة لمعاناة المرأة الريفية من المثكلات الماتهيات

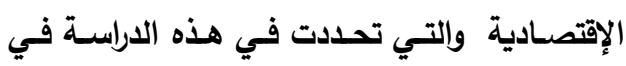
أربعة مشكلات فرعية وهم (ارتفاع تكاليف الزواج، الفقر، البطالة، سوء حالة المسكن ). وتم قياسها بأربعة أوزان (كبيرة، متوسطة، قليلة، لا أعاني)،

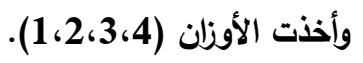

ثالثاً: المثكلات المجتمعية : ويقصد بها مستوي إدراك المرأة المبحوثة لمعاناة المرأة الريفية من المشكلات المجتمعية والتي تحددت في هذه الدراسة في ثمان مشكلات فرعية وهم (مثكلة الدروس الخصوصية، ونقـص خـــات التــامين الاجتمــاعي، ونقــص الخـــمات التعليميــة، ونقــص خـــــــات النقــل والاتصــالات، ونقــص خــــات الأمـن، ونقــص الخدمات الترفيهية، ونقص خدمات المياه والصرف والصف

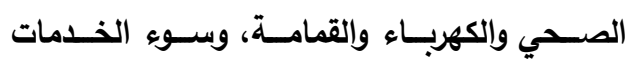

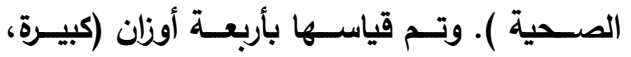


7-حيازة الأرض الزراعيـة : يعرض جدول (1) توزيـع

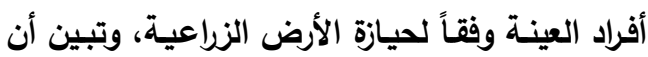
القيمـة المعبـرة عن حيـازة الأرض الزراعيـة إجمـالاً

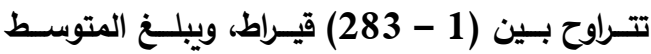
29.08 الحسـابي 28.05 درجسة بـانحراف معيسارئ

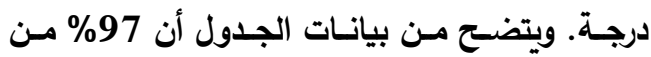

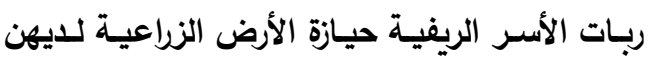

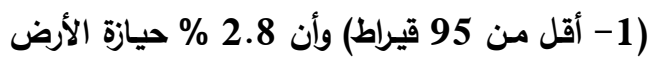
الزراعية لليهن (96 - أقل من 189 قيراط)، وأن

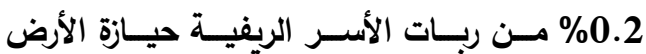
الزراعية لديهن (189 - 283 قيراط) 8-حيازة الحيوانـات المزرعية والطيور : يعرض جدول (89

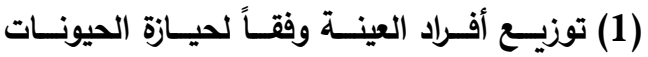
المزرعية والطيور، وتبين النتائج البحثية أن القيمة

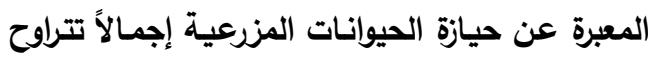

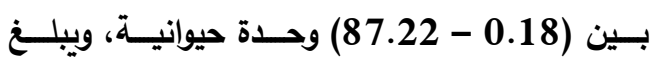
المتوسط الحسابي 23.008 درجة بانحراف معياري 20.75 درجـة. ويتضــح مـن بيانـات الجـدول أن 60.2 مـن ربـات الأسـر المبحوثـة لـيهين حيـازة

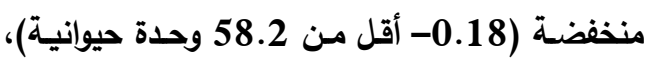

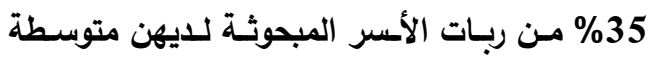

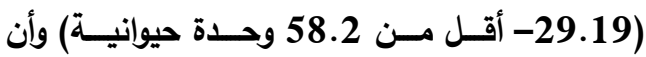

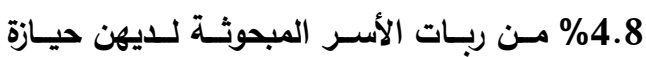
مرتفعة (58.2 - 78.22 وحدة حيوانية).

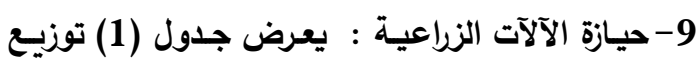
أفراد العينة وفقاً لحيازة لآلآت الزراعية، وتبين النتائج البحثية أن القيمة المعبرة عن حيازة الآلآت الزراعية ولئه

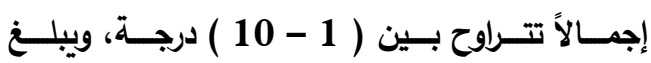
المتوسط الحسابي 3.005 درجة بانحراف معياري 3.002 درجة. ويتضح من بيانات الجدول أن 82\%

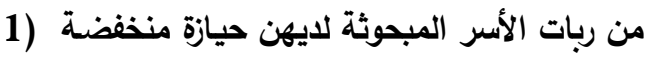

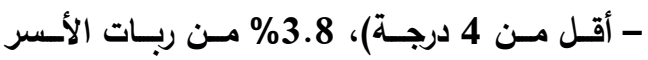

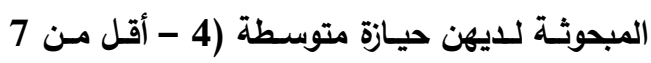
درجة) وأن 0.2\% من ربات الأسر المبحوثة لديهن

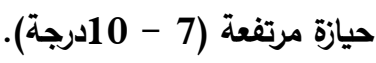

الثـهاة الإبتدائية وأن 8\% حاصـلات على الثـهادة الإعداديـة و2.8\% حاصـلات على الثـهادة الثانويـة

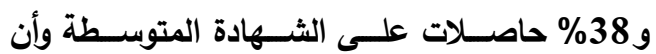

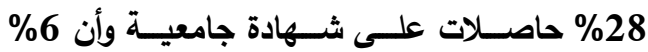
حاصلات على دراسات عليا. 4- الحالة العملية: يعرض جدول (1) توزيع أفراد العينة

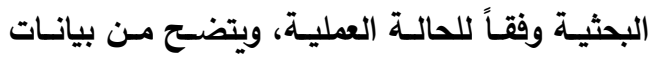

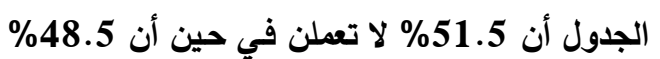

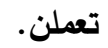
5 - الــخل الثـهري: يعـرض جدول (1) توزيـع أفراد العينة وفقاً للدخل الثهرى، وتبين النتائج البحثية أن القيمة المعبرة عن الدخل الثـهري للمبحوثات تتراوح

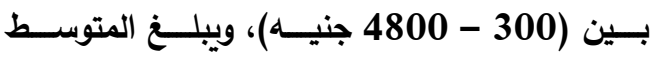
الحسـابي للـخل الثـهري للأسـرة 2065.21 جنيه ونيه بانحراف معياري 899.61 جنيه بعينـة ربـات الأسر

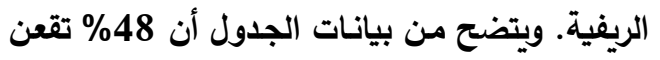
في الفئة التي تتراوح من (300 - أقل من 1800

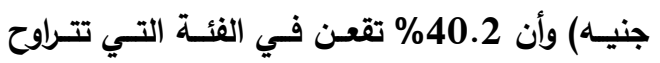

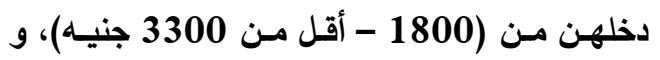

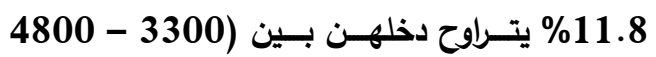

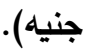
6- مستوى المعيثـة : يعرض جدول (1) توزيـع أفراد العينة وفقاً للمستوى المعيشة، وتبين النتائج البحثية أن القيمة المعبرة عن مستوي المعيثة إجمالاً تتراوح بين (64.13 - 138.40) درجـة، ويبلغ المتوسط الحسبـابي 100 درجسة بـانحراف معيـاري 13. 17.94

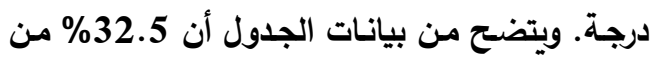

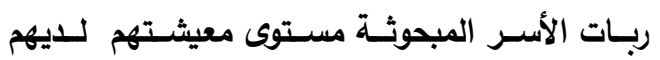
مـنـفض (64.13 - أقـلـل مسن 88.89 درجــة)، 40.8 من ربات الأسر المبحوثة مستوى معيشتهم متوسط (88.89 - أقل مـن 113.65 درجـة من وأن 26.8 من ربات الأسر المبحوثة مستوى معيشتهر مرتفع (113.65 - 138.40 درجة). 
جدول (1): توزيع أفراد العينة البحثية وفقا لمتغيرات الدراسة

\begin{tabular}{|c|c|c|c|c|c|}
\hline المئوية & العدد الع & 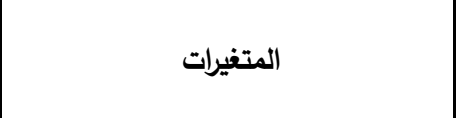 & المئوية & 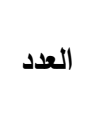 & 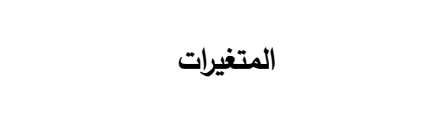 \\
\hline & & 10-الانفتاح الثقافي & & & 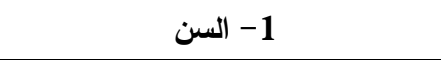 \\
\hline 42.8 & 171 & منخفض ( 12 - أقل من 23) & 20.8 & 83 & فئة عمرية أولي (18 - أقل من 34) \\
\hline 46.8 & 187 & متوسط ( 23 - أقل من 34 ) & 66.3 & 265 & فئة عمرية ثانية ( 35 - أقل من 51) \\
\hline 10.4 & 42 & مرتفع ( 34 - 44) & 13 & 52 & فئة عمرية ثالثة ( 52 - 67) \\
\hline \multirow[t]{2}{*}{$\% 100$} & 400 & المجموع & $\% 100$ & 400 & المجموع \\
\hline & & 11-الانفتاح الجغرافي & & & 2- الحالة الاجتماعية \\
\hline 24.2 & 97 & منخفض (5 - أقل من 10) & 63.8 & 255 & 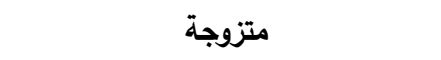 \\
\hline 53.5 & 214 & متوسط (10 - أقل من 15) & 25.5 & 102 & 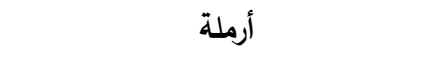 \\
\hline 22.3 & 89 & مرتفع (15 - 20) & 10.8 & 43 & مطلقة \\
\hline \multirow[t]{2}{*}{$\% 100$} & 400 & 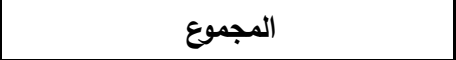 & $\% 100$ & 400 & المجموع \\
\hline & & 12-المشاركة الإجتماعية غير الرسمية & & & 3- الحالة التعليمية \\
\hline 53.5 & 214 & منخفض ( 13- أقل من 25) & 6 & 24 & أمي \\
\hline 46 & 184 & متوسط ( 25 - أقل من 37) & 4.8 & 19 & يقرأ ويكتب \\
\hline 0.5 & 2 & مرتفع ( 37 - 48) & 5.6 & 26 & إبتدائى \\
\hline \multirow[t]{2}{*}{$\% 100$} & 400 & المجموع & 8 & 32 & إعدادى \\
\hline & & 13-قيادة الرأي & 2.8 & 11 & ثانوى \\
\hline 58.8 & 235 & منخفض ( 7- أقل من 14) & 38 & 152 & شهادة متوسطة \\
\hline 37.2 & 149 & متوسط ( 14 - أقل من 21) & 28 & 112 & 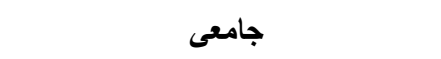 \\
\hline 4 & 16 & مرتفع ( 21 - 29) & 6 & 24 & دراسات عليا \\
\hline \multirow[t]{2}{*}{$\% 100$} & 400 & المجموع & $\% 100$ & 400 & المجموع \\
\hline & & 14-الرضا عن المجتمع المحلي & & & 4-الحالة العملية \\
\hline 5.5 & 22 & منذفض ( 7- أقل من 14) & 48.5 & 194 & تعمل \\
\hline 41 & 164 & متوسط ( 14 - أقل من 21) & 51.5 & 206 & ل الا تعل \\
\hline 53.5 & 214 & مرتفع ( 21 - 29) & $\% 100$ & 400 & المجموع \\
\hline \multirow[t]{2}{*}{$100 \%$} & 400 & المجموع & & & 5-الاخل الثهري \\
\hline & & 15-مستوي الطموح & 48 & 192 & 300 - أقل من 1800 \\
\hline 9.3 & 37 & منذفض ( 18- أقل من 25) & 40.2 & 161 & 1800 - أقل من 3300 \\
\hline 83 & 332 & متوسط ( 25 - أقل من 32) & 11.8 & 47 & $4800-3300$ \\
\hline 7.7 & 31 & مرتفع ( 32 - 40) & $\% 100$ & 400 & 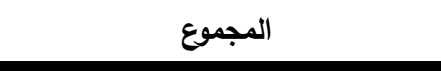 \\
\hline
\end{tabular}


تابع جدول (1): توزيع أفراد العينة البحثية وفقا لمتفيرات الاراسة

\begin{tabular}{|c|c|c|c|c|c|}
\hline المئوية & 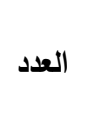 & المتغيرات & المئوية & العدد الع & المتغيرات \\
\hline \multirow[t]{2}{*}{$\% 100$} & 400 & 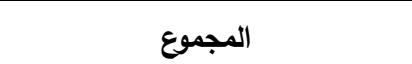 & & & 6-مستوي المعيثة \\
\hline & & 16-التخطيط للمستقبل & 32.5 & 130 & منخفض(64.13 -أقل من 88.89) \\
\hline 20.2 & 81 & منخفض (8- أقل من 12) & 40.8 & 163 & متوسط (88.89 - أقل من 113.65) \\
\hline 56.3 & 261 & متوسط ( 12 - أقل من 16) & 26.8 & 107 & مرتفع (113.65 -138.40) \\
\hline 14.5 & 58 & مرتفع ( 16 - 21) & $\% 100$ & 400 & 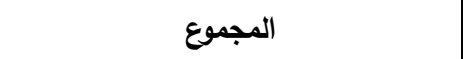 \\
\hline \multirow[t]{2}{*}{$\% 100$} & 400 & 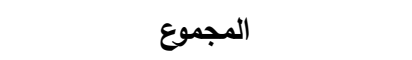 & & & 7-حجم الحيازة الزراعية \\
\hline & & 17-القوامة والمسئولية الاجتماعية & 97 & 388 & منخفض (1- أقل من 95) \\
\hline 8.3 & 33 & منخفض (19- أقل من 25) & 2.8 & 11 & متوسط (95- أقل من 189) \\
\hline 73 & 292 & متوسط ( 25 - أقل من 31) & 0.2 & 1 & مرتفع (189 - 283) \\
\hline 18.7 & 75 & مرتفع ( 31 - 36) & $\% 100$ & 400 & 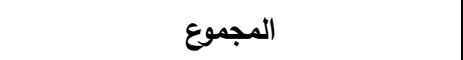 \\
\hline \multirow[t]{2}{*}{$\% 100$} & 400 & 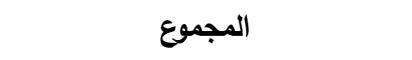 & & & 8-حيازة الحيوانات والطيور \\
\hline & & 18-الد|فعية للإنجاز & 60.2 & 241 & منخفض(0.18 - أقل من 29.19 ) \\
\hline 16.8 & 67 & منخفض (10- أقل من 13) & 35 & 140 & متوسط(29.19 - أقل من 58.2 ) \\
\hline 60.7 & 243 & متوسط ( 13 - أقل من 16) & 4.8 & 19 & مرتفع(58.2 - 87.22) \\
\hline 22.5 & 90 & مرتفع ( 16 - 18) & $\% 100$ & 400 & 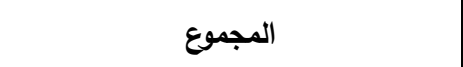 \\
\hline \multirow[t]{5}{*}{$\% 100$} & 400 & 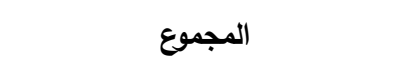 & & & 9-حيازة الآلآت الززاعية \\
\hline & & & 82 & 328 & منخفض ( 1 - أقل من 4) \\
\hline & & & 3.8 & 15 & متوسط ( 4 - أقل من 7) \\
\hline & & & 14.2 & 57 & مرتفع ( 7 - 10) \\
\hline & & & $\% 100$ & 400 & 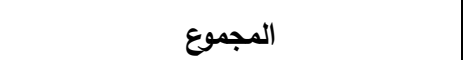 \\
\hline
\end{tabular}

الثقافي لايهن تتراوح بين (12 - أقل 23 درجة)،

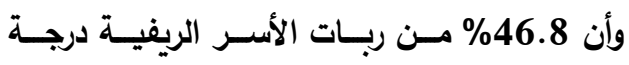

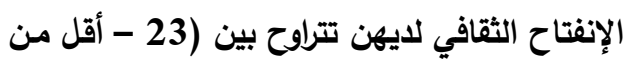
34 درجـة)، و10.4\% مـن ربـات الأسـر الريفيـة درجة الإنفتاح الثقافي لايهن (34 - 144 - 44 درجة).

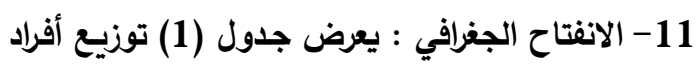
العينة البثثية وفقاُ لدرجة الانفتاح الجغرافي، وتبين
10- الانفتاح الثقافي : يعرض جدول (1) توزيع أفراد العينة البحثية وفقاً للإنفتاح الثقافي، وتبين النتائج

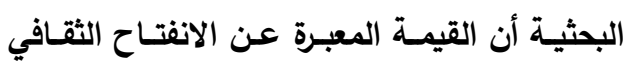

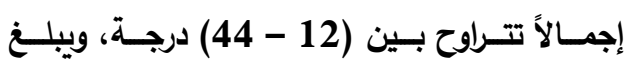
المتوسط الحسابي 25.45 درجة بانحراف معياري

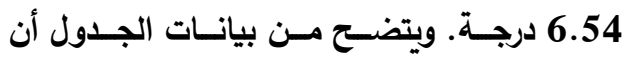
42.8 من ربـات الأسر الريفيـة درجـة الانفتـاح 
مسن 21 درجـة)، و4\% مـن ربـات الأسـر الريفيـة

قيادة الرأي لايهن (21 - 21 درجة)، ورجة).

14 - الرضـا عن المجتمع المحلي : يعرض جدول (1)

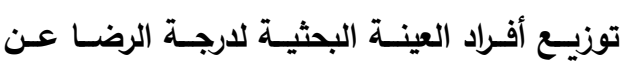

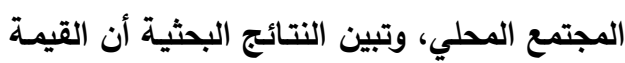

المعبرة عن الرضـا عن المجتمع المحلي إجمـالاً

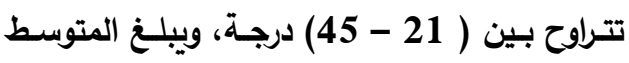

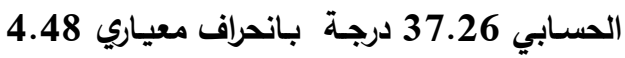

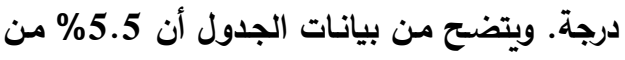

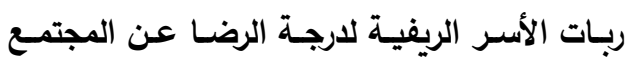

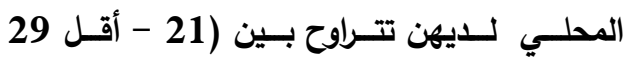

درجة)، وأن 41\% من ربات الأسر الريفية لدرجة

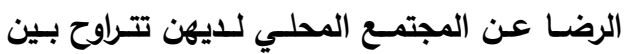

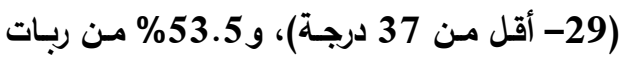

الأسر الريفية لارجـة الرضـا عن المجتمع المحلي

لايهن (37 - 45 درجة).

15- مستوي الطمـوح: يعرض جدول (1) توزيـع أفراد

العينـة البحثيـة لمستوي الطمـوح، وتبـين النتـائج

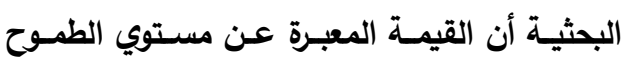

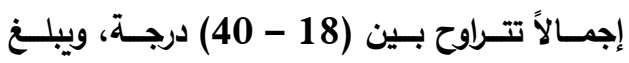

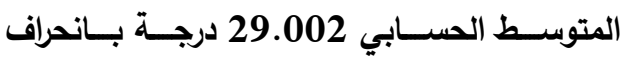

معياري 3.16 درجة.ويتضح من بيانات الجدول أن

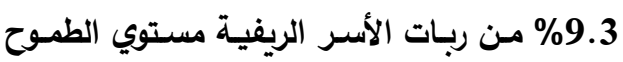

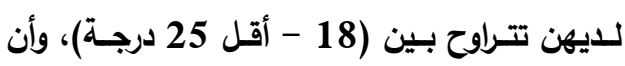

83 مـن ربـات الأسـر الريفيـة مستوي الطمـوح

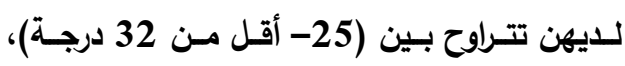

و7.7 من ربات الأسر الريفية مستوي الطموح

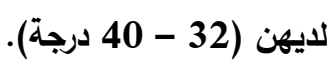

16- التخطيط للمستقبل : يعرض جدول (1) توزيع أفراد العينة البحثية للتخطيط للمستقبل، وتبين النتائج البحثية أن القيمة المعبرة عن التخطيط للمستقبل إجمــالاً تتــراوح بـين (8 - 14. المتوسط الحسابي 14.32 درجة بانحراف معياري
النتـائج البحثيـة أن القيمـة المبـرة عن الانفتـاح

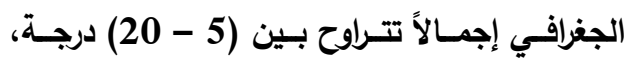
ويبلغ المتوسط الحسابي 12.96 درجـة بانحراف معياري 2.99 درجة. ويتضح من بيانات الجدول أن 24.2\% من ربات الأسر الريفية درجة الانفتاح

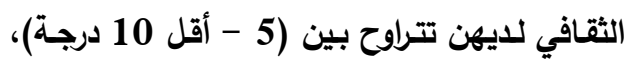
وأن 53.5\% مــن ربـات الأسـر الريفيـة درجــة

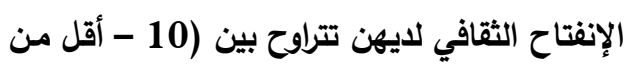
15 درجـة)، و22.3\% مـن ربـات الأسـر الريفيـة درجة الإنفتاح الثقافي لديهن (15 - 15 د 20 درجة). 12- المثاركة الاجتماعية غير الرسمية : يعرض جدول

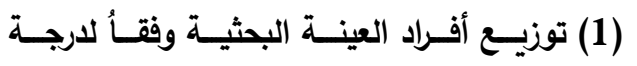
المشاركة الاجتماعية غير الرسمية، وتبين النتائج

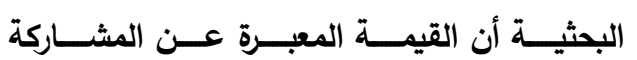

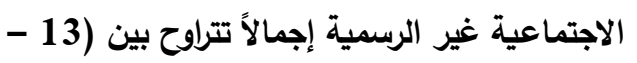
48) درجـة، ويبــــ المتوســ الحسبـابي 25.30

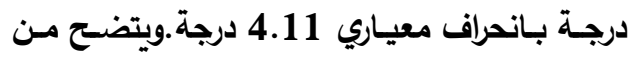

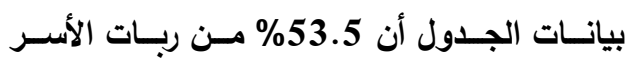
الريفيـة درجة المشـاركة الاجتماعية الغير رسمية

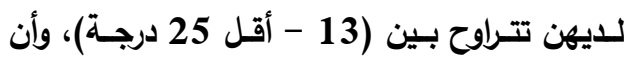
46 مـن ربـات الأسـر الريفيـة درجـة المشـاركة الاجتماعية غير الرسمية لايهن تتراوح بين (25-

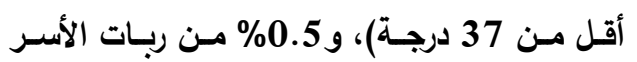
الريفية درجة المشاركة الاجتماعية غير الرسمية لايهن (37 - 48 درجة).

13- قيادة الرأي: يعرض جدول (1) توزيع أفراد العينة

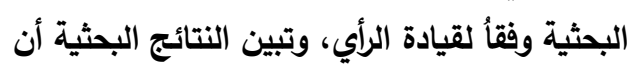

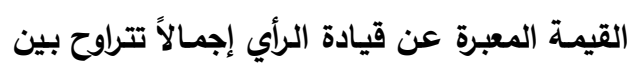

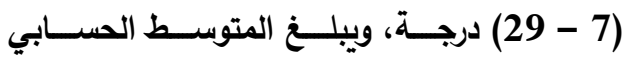

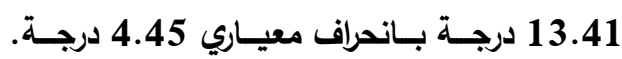
ويتضح من بيانات الجدول أن 58.8\% من دربان ربات

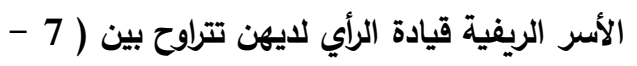

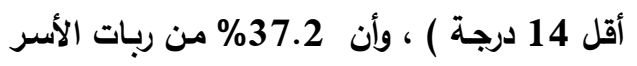

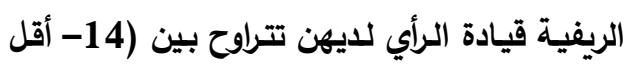


الريفيـة مستوي التخطيط للإنجـاز للديهن مرتفع

$$
\text { يتراوح بين (16 - } 18 \text { درجة). }
$$

النتائج ومناقشتها

ينتظم عرض النتائج أولا: تناول مستوي ادراك المرأة

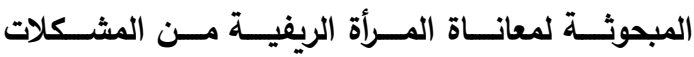
الاجتماعية، ثم وصف طبيعة العلاقة الارتباطية البسيطة بين المتغيرات المستقلة المدروسـة ومستوي ادراك المرأة

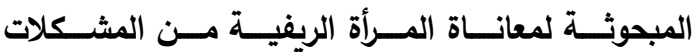

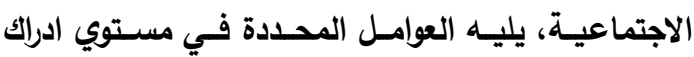

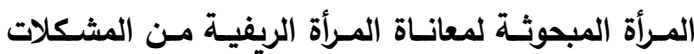
الإجتماعية بعينة الدراسة.

أولاً: مستوي إدراك المرأة الريفية للمشكلات الأسرية

1- مستوي ادراك المرأة المبحوثة لمعاناة المرأة الريفية من المثكلات الأسرية يوضح جدول (2) توزيع ربات الأسر الريفية المبحوثة وفقاً لمستوي ادراك المرأة المبحوثة لمعاناة المرأة الريفية من المشكلات الأسرية. وتبين النتائج البحثية أن القيمة المعبرة عن مستوي ادراك المرأة المبحوثة لمعاناة المرأة الريفية من المشكلات الأسرية

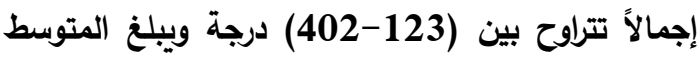
الحسابي 269.23 درجة، بإنحراف معياري 72.07 درجة. ويتضح من البيانات أن (0.5\%) من ربات الأسر دانعرات

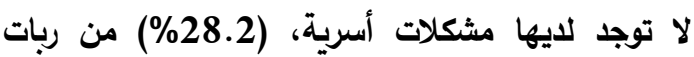
الأسر يعانون من المشكلات الأسرية بمستوي منخفض، لونكات (\%29.5\%) من ربات الأسر يعانون من المشكلات الأسرية بمستوي متوسط، (41.8\%) من ربات الأسر الريفية يعانون من المشكلات الأسرية بمستوي مرتفع . وتثير النتائج الواردة بالجدول إلي أن 41.8\% من ربات الأسر الريفية بعينة الدراسة مستوي ادراكهم لمعاناة المرأة الريفية من المشكلات الأسرية بمستوي مرتفع.
2.41 درجـة. ويتضــح مـن بيانـات الجـدول أن

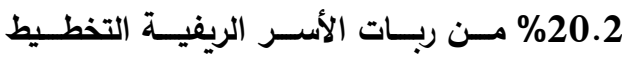
للمستقبل لليهمن منخفضة تتراوح بين (8 - أقل 12 درجة)، وأن 65.3\% من ربات الأسر الريفية التخطيط للمستقبل للديهن متوسطة تتراوح بين (12- أقل مـن 16 درجـة)، و14.5\% من ربـات الأسر الريفيـة التخطيط للمستقبل للايهن مرتفعـة ولته تتراوح بين (16 - 21 درجة).

17- القوامة والمسئولية الاجتماعية : يعرض جدول (1)

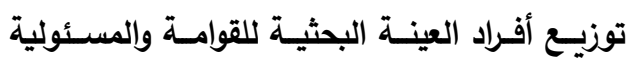

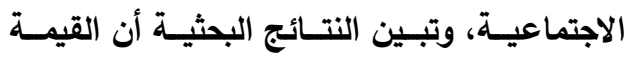

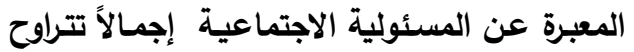
بين (19 - 36) درجة، ويبلغ المتوسط الحسابي 29.005 درجـة بـانحراف معياري 2.97 درجـة.

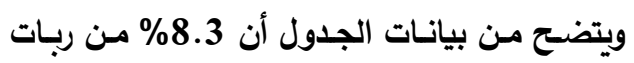
الأســر الريفيـة مسـتوي المســولية الاجتماعيـة منخفضة تتراوح بين (19 - أقل 25 درجة)، وأن 73 من ربات الأسر الريفية مستوي المسئولية الاجتماعية متوسطة تتراوح بين (25- أقل مـن 31 درجـة)، و18.7\% مـن ربـات الأسـر الريفيـة مستوي المسئولية الاجتماعية لايهن مرتفعة (31) - 36 - 36 درجة). 18- الدافعية لإنجاز : يعرض جدول (1) توزيع أفراد العينـة البحثيـة للتخطيط للإنجـاز، وتبين النتائج البحثيـة أن القيمـة المعبرة عن الدافعيـة للإنجـاز

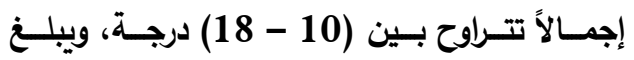
المتوسط الحسابي 15.1 درجـة بانحراف معياري

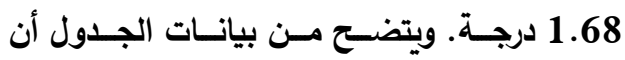
16.8 من ربات الأسر الريفية مستوي التخطيط للإنجـاز مـنففض يتـراوح بـين (10 - أقـل 13 درجـة)، وأن 60.7 \% مـن ربـات الأسـر الريفيـة مستوي التخطيط للإنجاز متوسط تتراوح بين (13 أقل مـن 16 درجـة)، و222.5 مـن ربـات الأسـر 
جدول (2): توزيع أفراد العينة البحثية وفقاً لمستوي ادراكهن لمعاناة المرأة الريفية من المثكلات الأسرية.

\begin{tabular}{|c|c|c|}
\hline$\%$ & 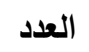 & 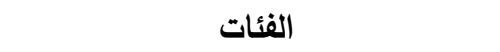 \\
\hline 0.5 & 2 & لا يوجد (123 درجة) \\
\hline 28.2 & 113 & منخفض (124- أقل من 217 درجة ) \\
\hline 29.5 & 118 & متوسط (217- أقل من 310 درجة ) \\
\hline 41.8 & 167 & مرتفع ( 310- 402 ) \\
\hline 100 & 400 & 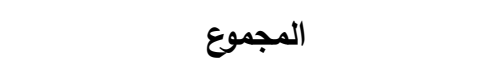 \\
\hline
\end{tabular}

المصدر: جمعت وحسبت من بيانات الاراسة الميدانية.

الأسرية وبلغ معامل الارتباط البسيط -0.100، 0.102، -0.127علي الترتيب. في حين لم يثبت وجود علاقة ارتباطية معنوية بين بقية المتغيرات المستقلة المدروسة ومستوي ادراك المرأة المبحوثة المباطة لمعاناة المرأة الريفية من المثكلات الأسرية.

3- العوامل المؤترة على مستوي إدراك المرأة المبحوثة لمعاناة المرأة الريفية من المشكلات

$$
\text { الأسرية بعينة الاراسة }
$$

ينص الفرض الإحصائي الأول علي أنه "لا يسهم أي متغير من المتغيرات المستقلة المدروسة إسهاماً معنوياً في تفسير التباين في مستوي ادراك المرأة المبحوثة لمعاناة المرأة الريفية من المثكلات الأسرية بعينة

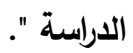

ولتحديد المتغيرات المستقلة المؤثرة في مستوي ادراك المرأة المبحوثة لمعاناة المرأة الريفية من المشكلات

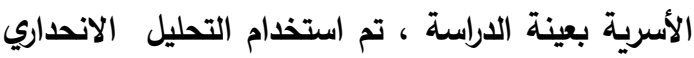
المتعدد الصاعد step-wise ، حيث أشارت النتائج الواردة بجدول (4) إلي معنوية هذا النموذج حتي الخطوة السابعة من التحليل ، وقد بلغت قيمة "ف" المحسوبة 152.295 وهي معنوية عند مستوي 0.01 وهذا يعني أن هناك سبع متغيرات مستقلة تؤثر في مستوي ادراك المرأة المبحوثة لمعاناة المرأة الريفية من المشكلات
2- وصف طبيعة العلاقة الارتباطية بين المتغيرات المستقلة المدروسة ومستوي ادراك المرأة المبحوثة لمعاناة المرأة الريفية من المشكلات الأسرية توضح نتائج جدول (3) قيم معاملات الإرتباط البسيط بين كل متفير من المتغيرات المستقلة المدروسة وبين المشكلات الأسرية بعينة ربات الأسر المبحوثة وتثير نتائج الجدول إلي وجود علاقة ارتباطية طردية الإنية بعنية معنوية عند المستوي الإحتمالي (0.01) بين متئير حيازة الآلآت الزراعية وبين ومستوي ادراك المرأة المبحوثة لمعاناة المرأة الريفية من المشكلات الأسرية وبلغت قيمة معامل الارتباط البسيط 0.147. ووجود علاقة ارتباطية عكسية عذد المستوي الاحتمالي (0.01)

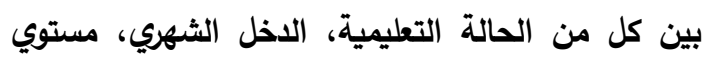
المعيشة، الانفتاح الثقافي، الانفتاح الجغرافي، الرضا عن

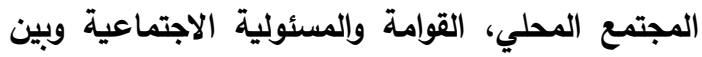

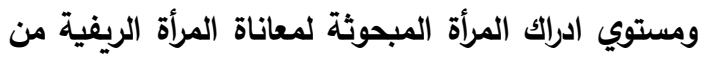
المشكلات الأسرية وبلغت قيم معاملات الارتباط البسيط - $0.372-$ ، $0.526-$ ، $0.368^{-}$، $0.350^{-}$ 0.366، -0.200، -0.314 علي الترتيب. وكذلك 0.360، تبين وجود علاقة ارتباطية عكسية عند المستوي

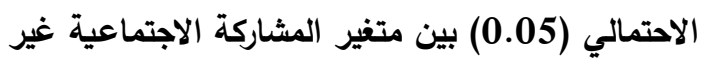

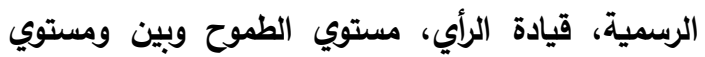
ادراك المرأة المبحوثة لمعاناة المرأة الريفية من المشكلات 
الاجتماعية، 2.5\% الي الرضا عن المجتمع المحلي،

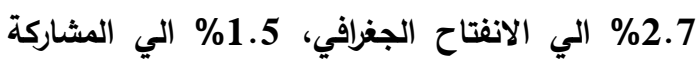

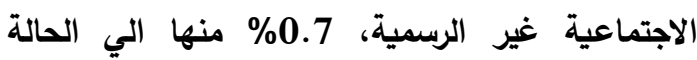

التعليمية، 0.8\% الي الدافعية للانجاز . أما باقي النسبة الإية

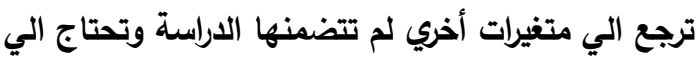

مزيد من البحث والتقصي للتعرف عليه.
الأسرية بعينة الدراسة، وقد بلغت قيمة معامل الارتباط المتعدد (R=0.652) ، وقيمة معامل التحديد 426. . .

وهذا يعني أن المتغيرات السبع المستقلة المؤثرة تبلغ

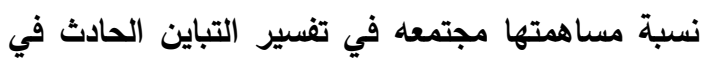

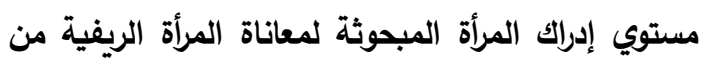
المشكلات الاسرية 42.6\% يرجع 27.7\% منها الي مستوي المعيثة، 6.7\% الي القوامة والمسئولية

جدول (3): قيم معاملات الارتباط البسيط بين المتغيرات المستقلة المدروسة ومستوي ادراك المبحوثات لمعاناة المرأة الريفية من المشكلات الأسرية.

\begin{tabular}{|c|c|c|}
\hline قيم معاملات الإرتباط البسيط & المتغيرات المستقلة & b \\
\hline $0.035-$ & 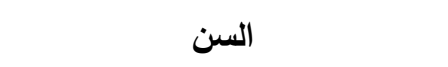 & 1 \\
\hline$* * 0.350-$ & الحالة التعليمية & 2 \\
\hline$* * 0.368$ & الاخل الشهري & 3 \\
\hline$* * 0.526-$ & مستوي المعيثة & 4 \\
\hline 0.050 & الحيازة الزراعية & 5 \\
\hline 0.024 & الحيازة الحيوانية والداجنية & 6 \\
\hline$* * 0.147$ & حيازة الآلآت الزراعية & 7 \\
\hline$* * 0.372-$ & الإنفتاح الثقافي & 8 \\
\hline$* 0.366-$ & الإنفتاح الجغرافي & 9 \\
\hline$* 0.100-$ & المشاركة الإجتماعية غير الرسمية & 10 \\
\hline$* 0.102-$ & 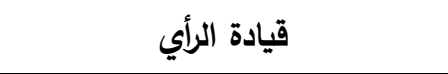 & 11 \\
\hline$* * 0.200-$ & الرضا عن المجتمع المحلي & 12 \\
\hline$* 0.127-$ & مستوي الطموح & 13 \\
\hline $0.032-$ & التخطيط للمستقبل & 14 \\
\hline$* * 0.314-$ & القوامة والمسئولية الإجتماعية & 15 \\
\hline 0.074 & الدافعية للإنجاز & 16 \\
\hline
\end{tabular}

المصدر: جمعت وحسبت من بيانات الدراسة الميدانية بإستخدم الحاسب الآلي.

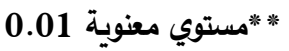
0.05 * مستوي معنوية 0.010 
جدول (4): المتغيرات المستقلة الأكثر إسهاماً في تفسير التباين في مستوي إدراك المبحوثات لمعاناة المرأة الريفية من

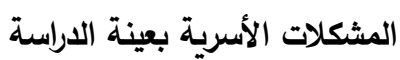

\begin{tabular}{|c|c|c|c|c|c|c|}
\hline \multicolumn{5}{|c|}{ المعاناة من المثكلات الأسرية } & \multirow[b]{2}{*}{ المتغيرات المؤثرة } & \multirow[b]{2}{*}{ خطوات التحليل } \\
\hline لاختبار معنوية & | المتغير التابع في & $\begin{array}{l}\text { Adjusted R } \\
\text { Square } \\
\text { معامل التحديد المعدل }\end{array}$ & $\begin{array}{c}\text { R قيم } \\
\text { Square } \\
\text { معل التحديد }\end{array}$ & $\begin{array}{c}\text { R } \\
\text { الارتباط } \\
\text { المتعدد }\end{array}$ & & \\
\hline$* 152.295$ & 27.7 & .275 & .277 & .526 & مستوي المعيشة & الخطوة الأولي \\
\hline$* * 104.231$ & 6.7 & .341 & .344 & .587 & القوامة والمسئولية الاجتماعية & الخطوة الثانية \\
\hline$* * 77.265$ & 2.5 & .364 & .369 & .608 & الرضا عن المجتمع المحلي & الخطوة الثالثة \\
\hline$* 64.817$ & 2.7 & .390 & .396 & .630 & الانفتاح الجغرافي & | الخطوة الرابعة \\
\hline **554.924 & 1.5 & .403 & .411 & .641 & المشاركة الاجتماعية غير & الخطوة \\
\hline$* * 47.130$ & 0.7 & .410 & .418 & .647 & الحالة التعليمية & الغطادسة \\
\hline$* * 41.484$ & 0.8 & .415 & .426 & .652 & الدافعية للإنجاز & الخطوة السابعة \\
\hline
\end{tabular}

المصدر: جمعت وحسبت من بيانات الدراسة الميدانية بإستخدم الحاسب الآلي.

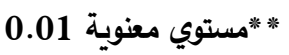
0.050 .01000

33.28 درجة. ويتضح من البيانات أن (0.3\%) من

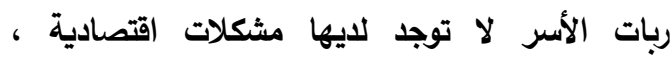
(20.5\%) من ربات الأسر يعانون من المشكلات لإنهات

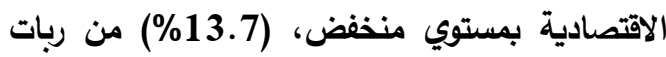

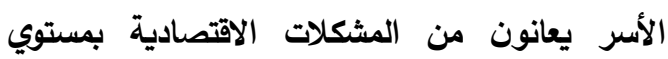
متوسط، (65.5\%) من ربات الأسر الريفية يعانون

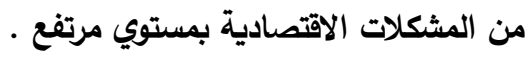
وتثير النتائج الواردة بالجدول إلي أن 65.5\%

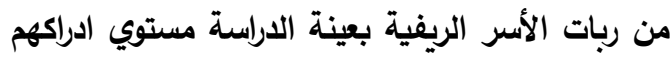

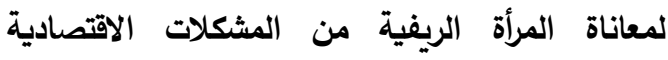

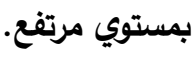

ثانياً: مستوي إدراك المرأة الريفية للمشكلات الإقتصادية

1- مستوي ادراك المرأة المبحوثة لمعاناة المرأة

$$
\text { الريفية من المشكلات الاقتصادية }
$$

يوضح جدول (5) توزيع ربات الأسر الريفية المبحوثة وفقاً لمستوي ادراك المرأة المبحوثة لمعاناة المرأة الريفية من المشكلات الاقتصادية. وتبين النتائج البحثية أن القيمة المعبرة عن مستوي ادراك المرأة المبحوثة لمعاناة المرأة الريفية من المئه المشكلات الاقتصادية إجمالاً تتراوح بين (49-174) درجة ويبلغ المتوسط الحسابي 132.7 درجة، بإنحراف معياري 
جدول (5): توزيع أفراد العينة البحثية وفقاً لمستوي ادراكهن لمعاناة المرأة الريفية من المشكلات الاقتصادية

\begin{tabular}{|c|c|c|}
\hline$\%$ & 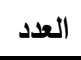 & 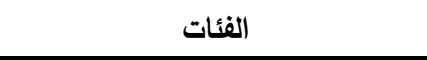 \\
\hline 0.3 & 1 & لا يوجد (49 درجة) \\
\hline 20.5 & 82 & منذفض (49- أقل من 91 درجة ) \\
\hline 13.7 & 55 & متوسط (91- أقل من 133 درجة ) \\
\hline 65.5 & 262 & مرتفع ( 133- 174 ) \\
\hline 100 & 400 & المجموع \\
\hline
\end{tabular}

المصدر : جمت وحسبت من بيانات الدراسة الميدانية.

علاقة ارتباطية معنوية بين بقية المتغيرات المستقلة المدروسة ومستوي ادراك المرأة المبحوثة لمعاناة المرأة الريفية من المشكلات الاقتصادية.

3- العوامل المؤثرة في مستوي ادراك المرأة المبحوثة لمعاناة المرأة الريفية من المشكلات

\section{الاقتصادية بعينة الاراسة.}

ينص الفرض الإحصائي الثاني علي أنه "لا يسهم أي الئه

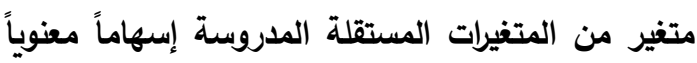

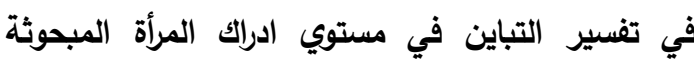
لمعاناة المرأة الريفية من المشكلات الاقتصادية بعينة

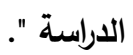

ولتحديد المتغيرات المستقلة المؤثرة في مستوي ادراك المرأة المبحوثة لمعاناة المرأة الريفية من المشكلات الاقتصادية بعينة الدراسة، تم استخدام التحليل الانحداري المتعدد الصاعد step-wise ، حيث أشارت النتائج الواردة بجدول (7) إلي معنوية هذا النموذج حتي الخطوة

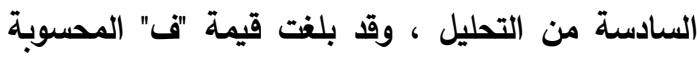
147.327 وهي معنوية عند مستوي 0.01 وهذا يعني أن هناك ست متغيرات مستقلة تؤثر في مستوي ادراك المرأة المبحوثة لمعاناة المرأة الريفية من المشكلات الاقتصادية بعينة الدراسة ، وقد بلغت قيمة معامل الارتباط المتعدد (R=0.616) ، وقيمة معامل التحديد 0.380 . وهذا يعني أن المتغيرات الست المستقلة المؤثرة

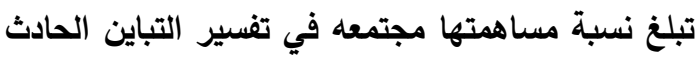

2- وصف طبيعة العلاقة الارتباطية البسيطة بين المتغيرات المستقلة المدروسة ومستوي ادراك

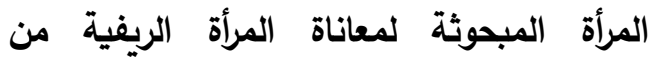
المشكلات الاقتصادية توضح نتائج جدول (6) قيم معاملات الإرتباط البسيط بين كل متغير من المتغيرات المستقلة المدروسة فئة وبين المثكلات الاقتصادية بعينة ربات الأسر المبحوثة

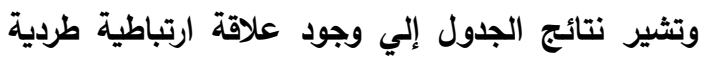

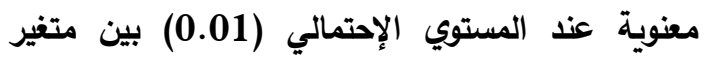

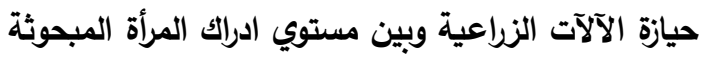

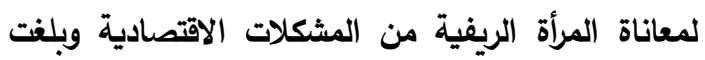
قيمة معامل الارتباط البسيط 0.157. ووجود علاقة لمن التراة ارتباطية عكسية عند المستوي الاحتمالي (0.01) بين

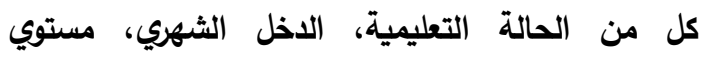

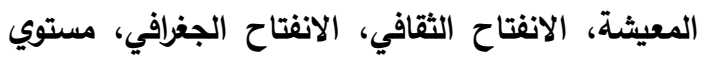

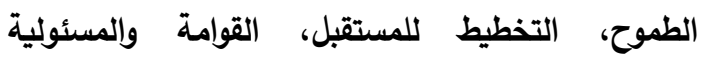
الاجتماعية وبين ومستوي ادراك المرأة المبحوثة لمعاناة

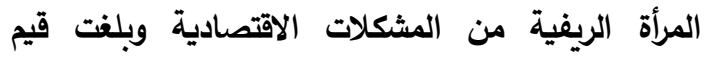

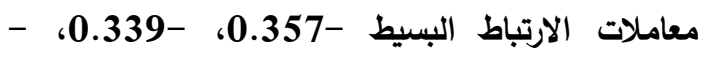
،0.140- ،0.180- ،0.476- ،0.352- ،0.520 -0.137 علي الترتيب. وكذلك تبين وجود علاقة ارتباطية عكسية عند المستوي الاحتمالي (0.05) بين متفير قيادة الرأي وبين ومستوي ادراك المرأة المبحوثة

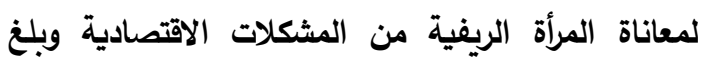
معامل الارتباط البسيط 0.123 في حين لم يثبت وجود الرئية 
المشاركة الاجتماعية غير الرسمية، 1.8\% الي الرضا في مستوي إدراك المرأة المبحوثة لمعاناة المرأة الريفية

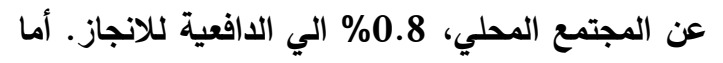

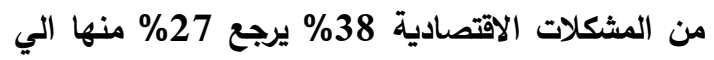

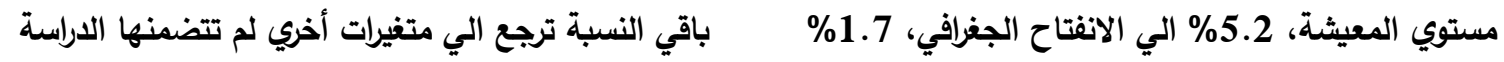

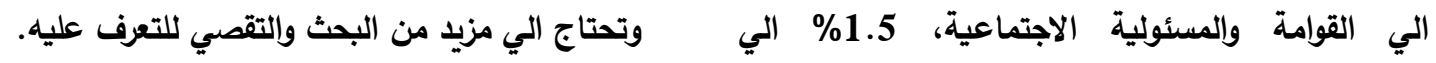
جدول (6): قيم معاملات الارتباط البسيط بين المتغيرات المستقلة المدروسة ومستوي ادراك المبحوثات لمعاناة المرأة الريفية من المشكلات الاقتصادية

\begin{tabular}{|c|c|c|}
\hline قيم معاملات الإرتباط البسيط & المتغيرات المستقلة & b \\
\hline $0.028-$ & 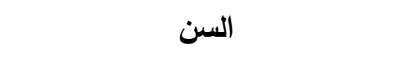 & 1 \\
\hline$* * 0.357-$ & الحالة التعليمية & 2 \\
\hline$* 0.339-$ & الاخل الشهري & 3 \\
\hline$* * 0.520-$ & مستوي المعيثة & 4 \\
\hline 0.056 & الحيازة الزراعية & 5 \\
\hline 0.093 & الحيازة الحيوانية والداجنية & 6 \\
\hline$* * 0.157$ & حيازة الآلآت الزراعية & 7 \\
\hline ***352- & الإنفتاح الثقافي & 8 \\
\hline$* * 0.476-$ & الإنفتاح الجغرافي & 9 \\
\hline $0.017-$ & المشاركة الإجتماعية غير الرسمية & 10 \\
\hline$* 0.123-$ & قيادة الرأي & 11 \\
\hline $0.069-$ & الرضا عن المجتمع المحلي & 12 \\
\hline ***0.180- & مستوي الطموح & 13 \\
\hline$* * 0.140-$ & التخطيط للمستقبل & 14 \\
\hline$* * 0.137-$ & القوامة والمسئولية الإجتماعية & 15 \\
\hline 0.064 & الدافعية للإنجاز & 16 \\
\hline
\end{tabular}

المصدر: جمعت وحسبت من بيانات الاراسة الميدانية بإستذام الحاسب الآلي.

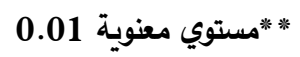
0.05 مستوي معنوية 0.01 مغنوية 
جدول (7): المتغيرات المستقلة الأكثر إسهاماً في تفسير التباين في مستوي ادراك المرأة المبحوثة لمعاناة المرأة الريفية من المشكلات الاقتصادية بعينة الدراسة

\begin{tabular}{|c|c|c|c|c|c|c|}
\hline \multicolumn{5}{|c|}{ المعاناة من المشكلات الاقتصادية } & \multirow[b]{2}{*}{ المتغيرات المؤثرة } & \multirow[b]{2}{*}{ خطوات التحليل } \\
\hline قين "ف" لاختبار & المفسر في المباين & $\begin{array}{c}\text { Adjusted } \\
\text { R Square } \\
\text { معامل التحديد المعدل }\end{array}$ & $\begin{array}{c}\text { R قيم } \\
\text { Square } \\
\text { معامل } \\
\text { التحديد }\end{array}$ & $\begin{array}{c}\text { R } \\
\text { الارتباط } \\
\text { المتعدد }\end{array}$ & & \\
\hline$* * 147.327$ & 27 & .268 & .270 & .520 & مستوي المعيثة & الخطوة الأولي \\
\hline$* * 94.190$ & 5.2 & .318 & .322 & .567 & الانفتاح الجغرافي & الخطوة الثانية \\
\hline$* * 67.654$ & 1.7 & .334 & .339 & .582 & القوامة والمسئولية & الخطوة الثالثة \\
\hline$* * 54.022$ & 1.5 & .347 & .354 & .595 & غشير الرسمية الاجتماعية & الخطوة الرابعة \\
\hline$* * 46.616$ & 1.8 & .364 & .372 & .610 & الرضا عن المجتمع & الخطوة الخامسة \\
\hline$* * 40.086$ & 0.8 & .370 & .380 & .616 & الدافعية للانجاز & الخطوة السادسة \\
\hline
\end{tabular}

المصدر: جمعت وحسبت من بيانات الدراسة الميدانية بإستخدم الحاسب الآلي.

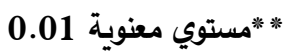

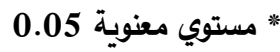

ويتضح من البيانات أن (0.3 \%) من ربات الأسر لا توجد لايها مشكلات مجتمعية ، (18\%) من ربات الأسر

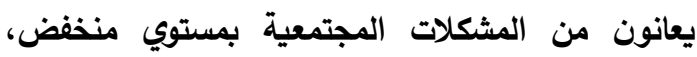

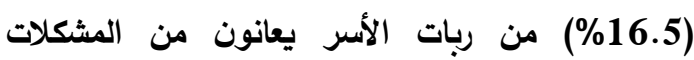
المجتمعية بمستوي متوسط، (65.2\%) من ربات الأسر الريفية يعانون من المشكلات المجتمعية بمستوي مرتفع. وتثير النتائج الواردة بالجدول إلي أن 65.2\% من ربات الأسر الريفية بعينة الدراسة مستوي ادراكهم لمعاناة المرأة الريفية من المشكلات المجتمعية بمستوي مرتفع.
ثالثاً: مستوي إدراك المرأة الريفية لمشكلات المجتمعية 1- مستوي ادرالك المرأة المبحوثة لمعاناة المرأة الريفية من المشكلات المجتمعية يوضح جدول (8) توزيع ربات الأسر الريفية المبحوثة وفقاً لمستوي ادراك المرأة المبحوثة لمعاناة المرأة الريفية من المشكلات المجتمعية. وتبين النتائج البحثية أن القيمة المعبرة عن مستوي ادراك المرأة المبحوثة لمعاناة المرأة الريفية من المشكلات المجتمعية

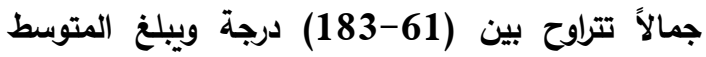
الحسابي 140.83 درجة، بإنحراف معياري 31.9

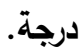


جدول (8): توزيع أفراد العينة البحثية وفقاً لمستوي ادراك المرأة المبحوثة لمعاناة المرأة الريفية من المشكلات المجتمعية.

\begin{tabular}{|c|c|c|}
\hline$\%$ & 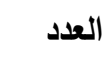 & 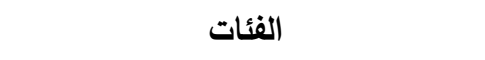 \\
\hline 0.3 & 1 & لا يوجد (61 درجة) \\
\hline 18 & 72 & منخفض (61- أقل من 102 درجة ) \\
\hline 16.5 & 66 & متوسط (102 - أقل من 143 درجة ) \\
\hline 65.2 & 261 & مرتفع ( 143 - 183 ) \\
\hline 100 & 400 & 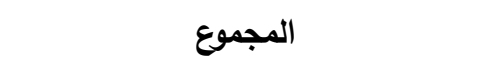 \\
\hline
\end{tabular}

المصدر: جمعت وحسبت من بيانات الدراسة الميدانية.

الاحتمالي (0.05) بين الحيازة الحيوانية واللاجنية وبين

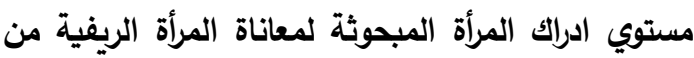
المشكلات المجتمعية وبلغت قيمة معامل الارتباط البسيط 0.119 .في حين لم يثبت وجود علاقة ارتباطية معنوية

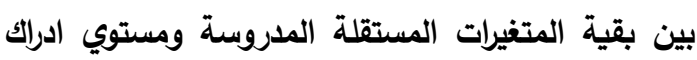

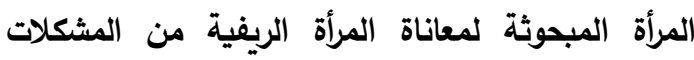

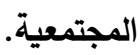

3- العوامل المؤثرة في مستوي ادراك المرأة المبحوثة لمعاناة المرأة الريفية من المشكلات

\section{المجتمعية بعينة الاراسة}

ينص الفرض الإحصائي الثالث علي أنه "لا يسهم أي الثئه متغير من المتغيرات المستقلة المدروسة إسهاماً معنوياً في تفسير التباين في مستوي ادراك المرأة المبحوثة لمعاناة المرأة الريفية من المشكلات المجتمعية بعينة

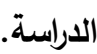

ولتحديد المتغيرات المستقلة المؤثرة في مستوي ادراك

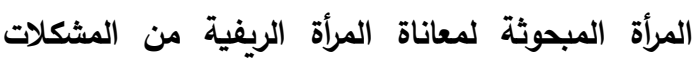

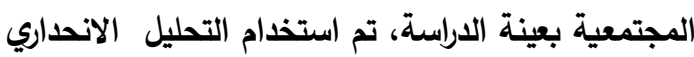
المتعدد الصاعد Step-wise ، يث أثنارت النتائج الواردة بجدول (10) إلي معنوية هذا النموذج حتي الخطوة التاسعة من التحليل.
2-وصف طبيعة العلاقة الارتباطية البسيطة بين

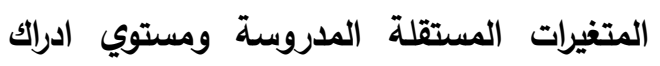

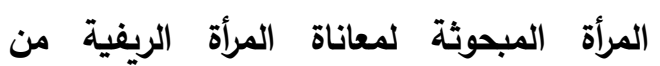
المشكلات المجتمعية

توضح نتائج جدول (9) قيم معاملات الإرتباط البسيط بين كل متغير من المتغيرات المستقلة المدروسة الإتئ وبين المشكلات المجتمعية بعينة ربات الأسر المبحوثة وتثير نتائج الجدول إلي وجود علاقة ارتباطية طردية الجئية

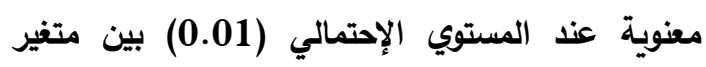

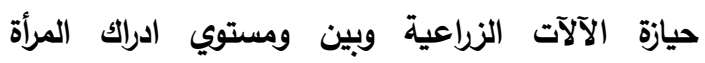

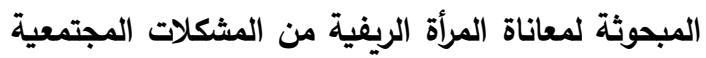
وبلغت قيمة معامل الارتباط البسيط 0.183. ووجود علاقة ارتباطية عكسية عند المستوي الاحتمالي (0.01)

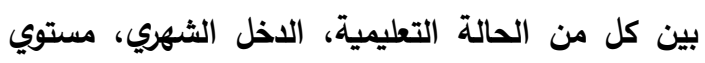

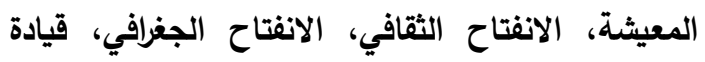

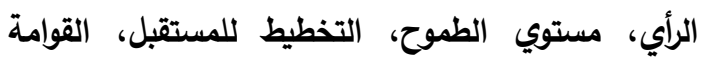
والمسئولية الاجتماعية وبين ومستوي ادراك المرأة المبحوثة لمعاناة المرأة الريفية من المشكلات المجتمعية وبنية

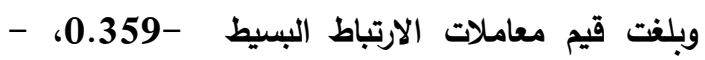
،0.131- 0.445- 0.369- 0.497- ، ، -0.211، - 0.131، - 0.143علي الترتيب. تبين أيضاً وجود علاقة ارتباطية طردية عند المستوي 
المشكلات المجتمعية 39\% يرجع 24.7\% منها الي

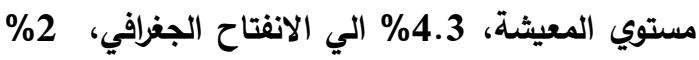

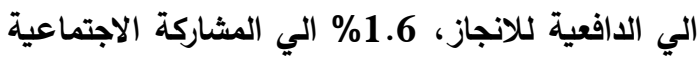
غير الرسمية، 2.1\% الي الرضا عن المجتمع المحلي،

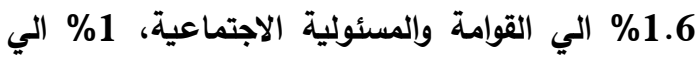

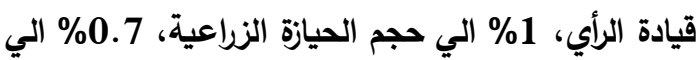

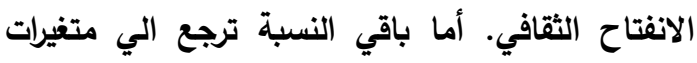

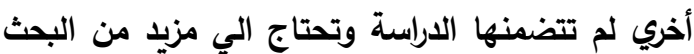
والتقصي للتعرف عليها.
وقد بلغت قيمة "ف" المحسوبة 130.898 وهي معنوية عند مستوي 0.01 وهذا يعني أن هناك تسع فئ فئل متفيرات مستقلة تؤثر في مستوي ادراك المرأة المبحوثة

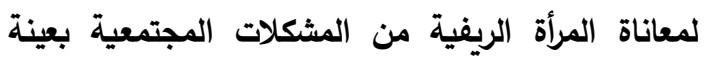
الدراسة، وقت بلغت قيمة معامل الارتباط المتعدد (R0.625 )، وقيمة معامل التصديد 0.390. وهذا يعني أن المتغيرات التسع المستقلة المؤثرة تبلغ نسبة مساهمتها مجتمعه في تفسير التباين الحادث في

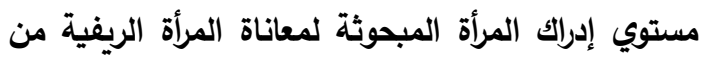

جدول (9): قيم معاملات الارتباط البسيطة بين المتغيرات المستقلة المدروسة ومستوي ادراك المرأة المبحوثة لمعاناة المرأة الريفية من المشكلات المجتمعية

\begin{tabular}{|c|c|c|}
\hline قيم معاملات الإرتباط البسيط & المتغيرات المستقلة & b \\
\hline 0.006 & 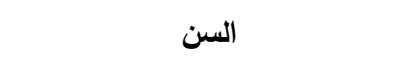 & 1 \\
\hline$* * 0.359-$ & الحالة التعليمية & 2 \\
\hline$* * 0.348-$ & الاخل الثهري & 3 \\
\hline$* * 0.497-$ & مستوي المعيثة & 4 \\
\hline 0.083 & الحيازة الزراعية & 5 \\
\hline *0.119 & الحيازة الحيوانية والداجنية & 6 \\
\hline$* * 0.183$ & حيازة الآلآت الزراعية & 7 \\
\hline$* * 0.369-$ & الإنفتاح الثقافي & 8 \\
\hline ***0.445- & الإنفتاح الجغرافي & 9 \\
\hline 0.027 & المشاركة الإجتماعية غير الرسمية & 10 \\
\hline$* * 0.131-$ & قيادة الرأي & 11 \\
\hline $0.061-$ & الرضا عن المجتمع المحلي & 12 \\
\hline$* * 0.211-$ & مستوي الطموح & 13 \\
\hline$* * 0.131-$ & التخطيط للمستقبل & 14 \\
\hline$* * 0.143-$ & القوامة والمسئولية الإجتماعية & 15 \\
\hline 0.087 & الدافعية للإنجاز & 16 \\
\hline
\end{tabular}

المصدر: جمعت وحسبت من بيانات الدراسة الميدانية بإستخدم الحاسب الآلي. 0.01 مستوي معنوية"**" 
F. A. Salama, et al.,

جدول (10): المتغيرات المستقلة الأكثر إسهاماً في تفسير التباين في مستوي ادراك المرأة المبحوثة لمعاناة المرأة الريفية من المشكلات الأسرية بعينة الاراسة

\begin{tabular}{|c|c|c|c|c|c|c|}
\hline \multicolumn{5}{|c|}{ المعاناة من المثكلات المجتمعية } & \multirow[b]{2}{*}{ المتغيرات المؤثرة } & \multirow[b]{2}{*}{ خطوات التحليل } \\
\hline قعيم "ف" لاختبار & المفسر في المتباين & $\begin{array}{c}\text { Adjusted } \\
\text { R Square } \\
\text { معامل التحديد المعدل }\end{array}$ & $\begin{array}{c}\text { R قيم } \\
\text { Square } \\
\text { معامل } \\
\text { التحديد }\end{array}$ & $\begin{array}{c}\text { R } \\
\text { الارتباط } \\
\text { المتعدد }\end{array}$ & & \\
\hline$* * 130.898$ & 24.7 & .246 & .247 & .497 & مستوي المعيثة & الخطوة الأولي \\
\hline$* * 80.939$ & 4.3 & .286 & .290 & .538 & الانفتاح الجغرافي & الخطوة الثانية \\
\hline$* * 59.385$ & 2 & .305 & .310 & .557 & الدافعية للانجاز & الخطوة الثالثة \\
\hline$* * 47.691$ & 1.6 & .319 & .326 & .571 & المشاركة الاجتماعية غير & الخطوة الرابعة \\
\hline$* * 41.921$ & 2.1 & .339 & .347 & .589 & الرضا عن المجتمع المحلي & الخطوة الخامسة \\
\hline$* * 37.254$ & 1.6 & .353 & .363 & .602 & القوامة والمسئولية & الخطوة السادسة \\
\hline$* * 33.259$ & 1 & .361 & .373 & .610 & قيادة الرأي & الخطوة السابعة \\
\hline$* * 30.352$ & 1 & .370 & .383 & .619 & حجم الحيازة الزراعية & الخطوة الثامنة \\
\hline$* * 27.715$ & 0.7 & .376 & .390 & .625 & الانفتاح الثقافي & الخطوة التاسعة \\
\hline
\end{tabular}

المصدر: جمعت وحسبت من بيانات الدراسة الميدانية بإستخدم الحاسب الآلي.

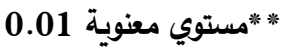

للقتصاد الزراعي والارشاد الزراعي والمجتمع الريفي،

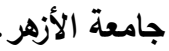
اسماعيل، بسمة محمد أحمد (2017). مستوي معرفة وتنفيذ المرأة الريفية بالتوصيات الصحية والغذائية السليمة في محافظة الثرقية، رسالة ماجستير ، قسم الاقتصاد الزراعي، جامعة الزقازيق .

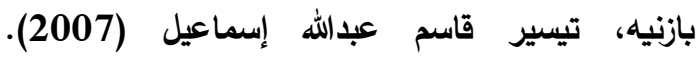

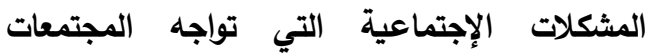

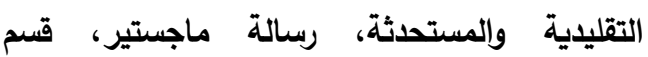
الاقتصاد الزراعي، كلية الزراعة، جامعة طنطا. بالي، عبدالجواد السيد (1996). تبني تكنولوجيا الإنتاج الحيواني بين زراع مركز قلين بحافظة كفر الثيخ، رسالة دكتوراه، كلية الزراعة، جامعة طنطا. ابراهيم، محد مصطفي محمد (2017). البطالة وعلاقتها بالجريمة في المجتمع المصري دراسة مديمة

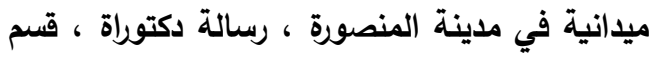
علم الاجتماع ، كلية الاداب ، جامعة المنصورة .

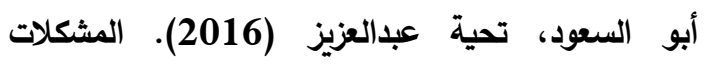
الاجتماعية للأسر الريفية بإحدي قرئ محافظة البحيرة، رسالة ماجستير، قسم تنمية الأسر الريفية، لاجئه كلية الاقتصاد المنزلي، جامعة الأزهر. أبو حليمة، وفاء أحمد (2005). تفعيل مشاركة المرأة الريفية في حل المشكلات المعاصرة في الأسرة الريفية، دراسة مقدمة الي اللجنة العلمية الائمة 


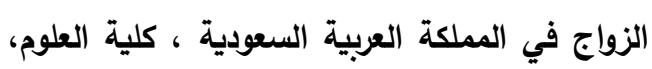

جامعة تبوك ، المملكة العربية السعودية.

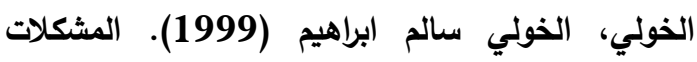

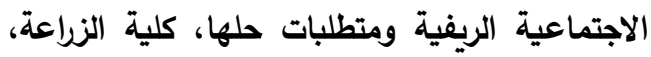

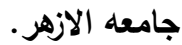

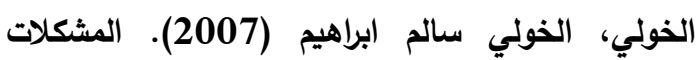

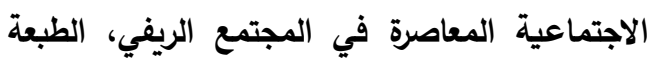

الاولي، كلية الزراعة، القاهرة جامعة الازهر. الخولي، سناء (2005). مدخل إلي علم الاجتماع، دار

المعرفة الجامعية للنشر والتوزيع، الأسكندرية.

دعدور، شرين مصطفي رزق مصطفي (2017). الابعاد

الاجتماعية والاقتصادية لظاهرة الطلاق المبكر دراسة

ميدانية في مدينة المنصورة، رسالة دكتوراة، قسم

علم الاجتماع، كلية الاداب، جامعة المنصورة.

دليل التنمية البشرية لمحافظة المنوفية، 2015.

الاليمي، خلف حسين علي (2009). تخطيط الخدمات

المجتمعية والبنية التحتية أسس - معايير -

تقنيات، الطبعة الأولي، عمان.

ديكو ، مصطفي (2008). علاقة الفقر ببعض

المشكلات الاجتماعية في الاسرة الريفية بمحافظة

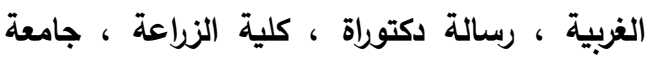

الأزهر.

الرفاعي ، مي فتحي حسان (2018). تغير النسق

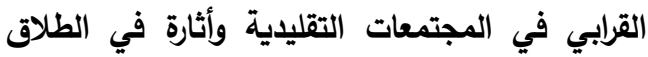

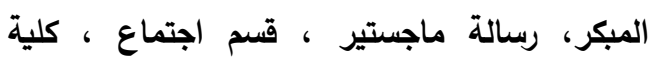

الاداب، جامعة المنصورة .

ريحان ، أية عبد الناصر محمد منصور (2018).

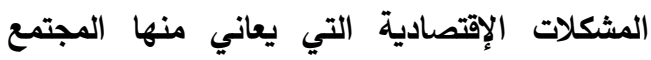
المصري بعد ثورتين وأثر ذلك علي منظومة القيم

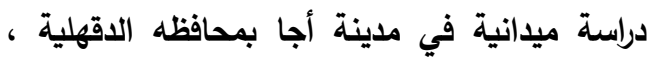

رسالة ماجستير ، قسم علم الاجتماع ، كلية الاداب .

ريحان، جاسنت إبراهيم إبراهيم. الزواج المبكر وعلاقته

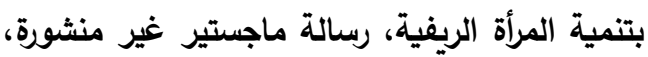

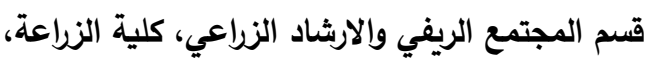

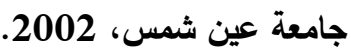

بيان السكان التقديري مركز شبين الكوم، محافظة

المنوفية، مركز المعلومات ودعم اتخاذ القرار، إدارة

الحاسب الآلي، عام 2016.

بيان السكان التقديري مركز منوف، محافظة المنوفية، مركز المعلومات ودعم اتخاذ القرار، إدارة الحاسب

$$
\text { الآلي، عام } 2016 .
$$

بيومي، محمد أحمد (1993). المثكلات الاجتماعية

دراسات نظرية وتطبيقية، دار المعرفة الجامعية

للنشر والتوزيع، الإسكندرية.

بيومي، محمد أحمد (2009). المشكلات الاجتماعية

دراسات نظرية وتطبيقية، دار المعرفة الجامعية

للنشر والتوزيع، الإسكندرية.

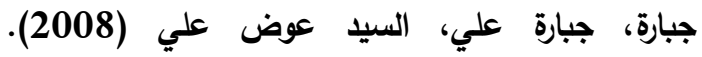

المشكلات الاجتماعية، دار الوفاء للنشر والتوزيع،

الطبعة الأولي، الاسكندرية.

جعف ، نجلاء محمد سعد (2009). المشكلات

الاجتماعية والنفسية المرتبطة بالطلاق في مرحلة

مبكرة من الزواج، رسالة ماجستير ، كلية الخدمة الاجتماعية ، جامعة حلوان.

جلبي، علي عبدالرازق، السيد عبدالعاطي السيد، محمد

أحمد بيومي، محمد علي محمد البدوي (1999).

علم الاجتماع والمشكلات الاجتماعية، دار المعرفة الجامعية للنشر والتوزيع، الإسكنرية.

الجهاز المركزي للتعيئة العامة والإحصاء المصري، الإنكية، عدد

سكان محافظة المنوفية، عام 2019.

الجهاز المركزي للتعبئة والإحصاء المصري، إجمالي

$$
\text { سكان مصر، عام } 2016 .
$$

حسانين، أمل حسانين محمد (2010). فاعلية برنامج إرشادي لتنمية وعي ربة الأسرة بالدور الإنمائي

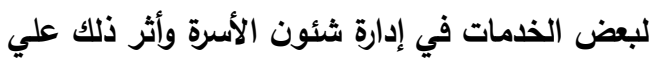
المناخ الأسري، رسالة دكتوراه، قسم إدارة المنزل ومؤسسات الأسرة والطفولة، كلية الإقتصاد المنزلي،

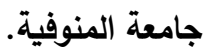
خليل، انتصار علي (2016). استخدام تقنية الانحدار

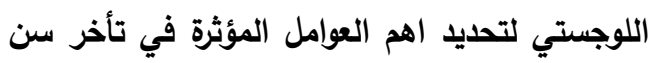


كليات البنات بالرياض ، قسم التربية وعلم النفس ، كلية التربية ، الرياض. الصديقي، سلوي عثمان عباس، عبد المحي محمود حسن (2000). الاسرة والسكان من متطور الذامة الاجتماعية، دار المعرفة الاجتماعية، الاسكندرية.

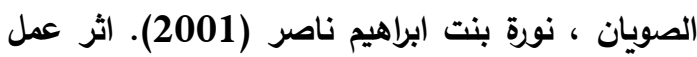

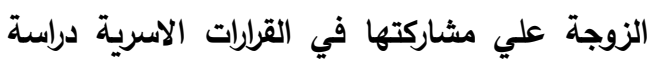
مقارنة لعينة من الزوجات العاملات وغير العاملات

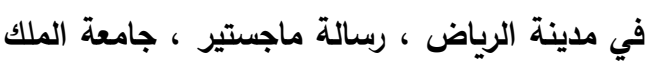
سعود ، الرياض. العابدي، لقاء عبدالهادي مسير : صراع الأدوار عند الراض.

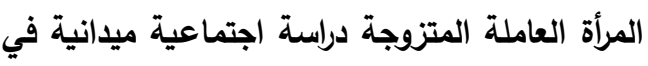
مدينة الايوانية، قسم علم الاجتماع، كلية الآداب، جامعة القادسية، 2014. عبد الحافظ ، أميرة عادل محمود (2015). معوقات تطبيق التقييم الذاتي وخطط التحسين المدرسي بمراحل التعليم قبل الجامعي لتحقيق الجودة دراسة

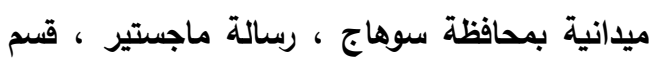
اصول التربية ، كلية التربية ، جامعة سوهاج. عبد العال ، أميرة حسن (2011). ادارة المرأة المعيلة

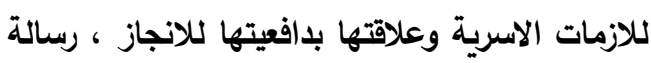

$$
\text { دكتوراة ، كلية التربية ، عين شمس. }
$$

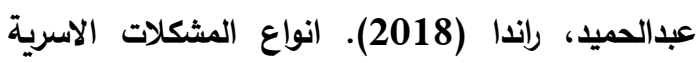

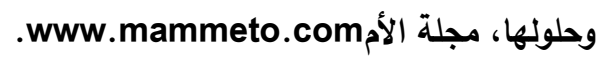
عبدالعزيز، أسماء سعيد (2002): المشكلات الأسرية في بيئات متباينة وإنعكاساتها علي أداء الأدوار الاجتماعية دراسة سيكولوجية مقارنة في الريف والحضر في ضوء التغيرات الاجتماعية والإقتصادية المعاصرة، رسالة ماجستير، معهر الاراسات والبحوث البيئية، جامعة عين شمس.

العتيبي ، بدرية بنت محمد مسعود (1994). الاثار

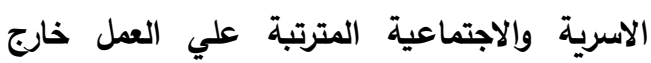

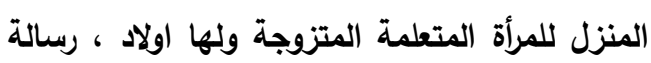

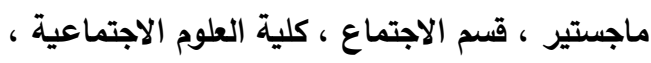

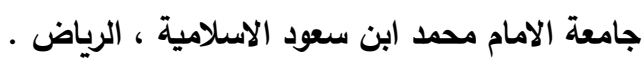

السبعاوي ، هناء جاسم محمد (2007). أثر الزواج المبكر للفتيات في عملية التنشئة الاجتماعية دراسة هاءئ ميدانية في مدينة الموصل ، دراسات الموصل ، العدد

السعيد ، رنيا السعيد عبد الهادي (2012). بعض مشكلات المرأة العاملة في المجال التعليمي دراسة

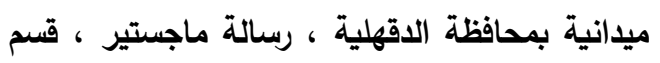
أصول التربية، كلية التربية ، جامعة المنصورة.

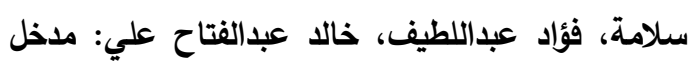

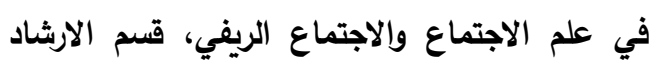

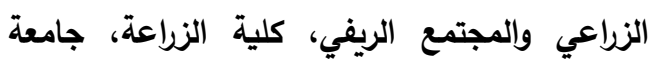

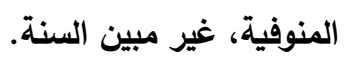

سلطان ، راندا يوسف محمد ، محمد جمال الدين راثد، الدين،

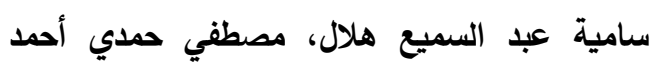

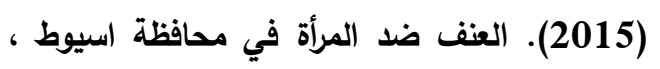

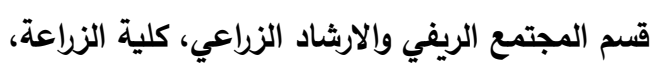
جامعة اسيوط. السيد ، مرفت صدقي عبد الوهاب (2012). بعض الإط

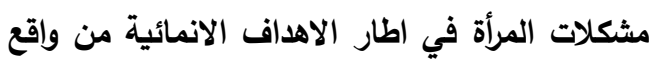

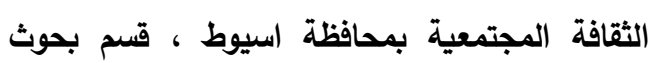

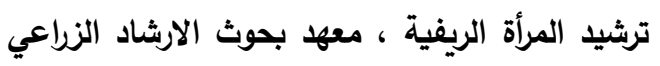
والتنمية الريفية ، مركز البحوث الزراعية، الجيزة .

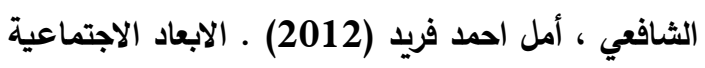

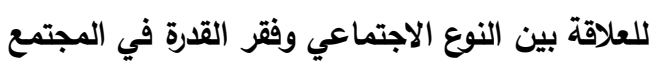

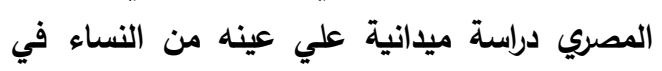

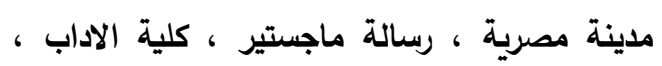
جامعة المنوفية. الثمري، حسين عباس حسين (2015). المشكلة الإقتصادية وأسبابها وطرق الأنسان حلها في الأنظمة الإقتصادية المختلفة، شيكة جامعة بابلة ولابل، uobabylon.edu.iq الثمسان ، منيرة بنت عبداللة بن محمد (2005). التوافق الزواجي وعلاقته بأساليب المعاملة الزوجية وبعض سمات الثخصية دراسة مقارنة بين العاملات

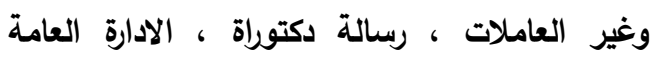


مجلة الجامعة الإسلامية للدراسات التربوية والنفسية، المجلد الحادي والعشرون، العدد الأول. غيث، محمد عاطف (1981). المشاكل الاجتماعية والسلوك الإنحرافي، دار المعرفة الجامعية للنشر والتوزيع.

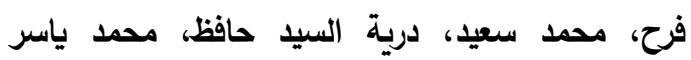

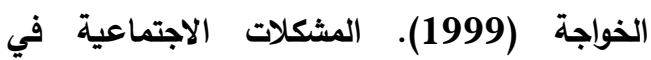
المجتمع المصري، دار المعرفة الجامعية، الاسكندرية. المتولي ، بدوي محمد ابراهيم (2008). ظاهرة الدروس فيكانه

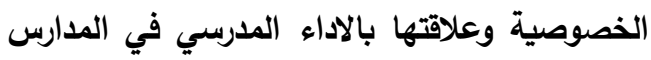
الثانوية العامة في كل من الريف والمدينة دراسة

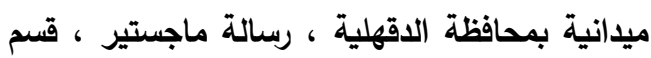
اصول التربية ، كلية التربية ، جامعة المنصورة.

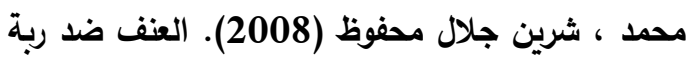
الاسرة وعلاقة بدافيتها للانجاز ، كلية الاقتصاد المنزلي ، جامعة المنوفية. محمود ، طارق محمد أحمد حسين (2019). دراسة

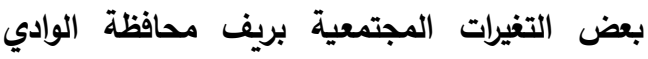

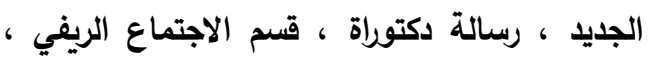
كلية الزراعة ، جامعة أسيوط . المداح، سماح محمد عبدالسلام عبدالحفيظ (2009). المشكلات الاجتماعية للشباب الريفي مركز كفر

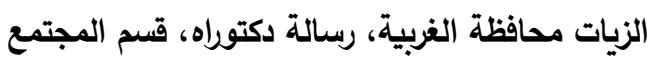
الريفي، كلية الزراعة، جامعة طنطا. المرسي، بسام السعيد رياض (2005). ظاهرة التعليم المدرسي في رياض الاطفال بين الفكر والتطبيق، رسالة ماجستير، فسم اصول التربية ، كلية التربية ، جامعة المنصورة. مشعل، رباب السيد عبد الحميد (2016). التوافق الزواجي وعلاقتة بالعنف الاسري دراسة ميدانية مقارنة بين مصر والسعودية ، مجلة بجوث التربية

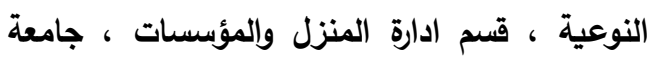

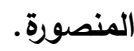

عرابي، مرة أحمد نبيل صادق (2006). الابعاد الاجتماعية والاقتصادية لظاهرة الدروس الخصوصية

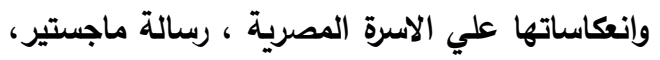
قسم الاداب كلية الاداب، جامعة المنصورة.

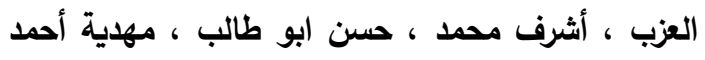

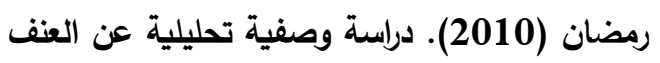
الأسري الموجه ضد المرأة الريفية بمحافظة كفر الثيخ ، مجلة العلوم الاقتصادية والاجتماعية

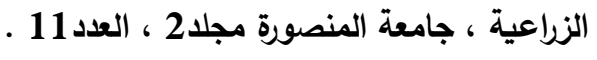
العزبي، محمد إبراهيم (2017). كيفية تصميم وتحديد

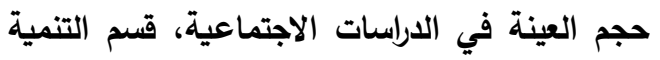
الريفية، كلية الزراعة، جامعة الإسكندرية.

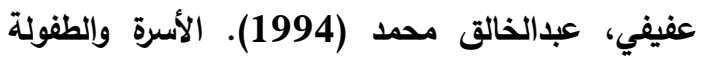
النظرية والتطبيق، القاهرة، مكتبة عين شمس. علام، صلاح الدين محمود (1985): تحليل البيانات في البحوث النفسية والتربوية، دار الفكر العربي. علي ، رويدة السيد ابو العلا (2008). التغير الاجتماعي وظاهرة الطلاق في المجتمع المصري دراسة ميدانية علي عينة من حديثي الزواج في

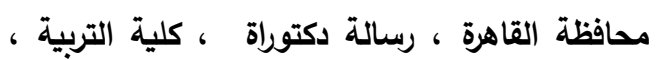

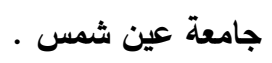
علي ، عبد العزيز حسن فضل البصير (2017). اثر التغير الاجتماعي والاقتصادي علي تأخر سن الزواج التعليز

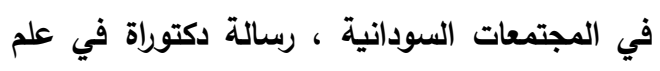
الاجتماع ، كلية الاراسات العليا ، جامعة السودان للعلوم والتكنولوجيا. علي ، هيبة علي محمود (2018). أثر المؤسسة التعليمية علي مشاركة طلاب المدراس في قضايا المجتمع ببعض قري محافظة الدقهلية ، رسالة

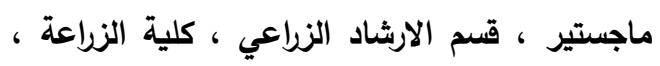
جامعة المنصورة. العواودة، أمل سالم، جهاد السعايدة، هناء الحديدي

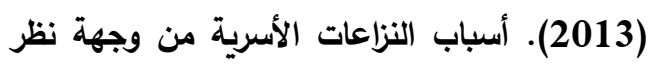

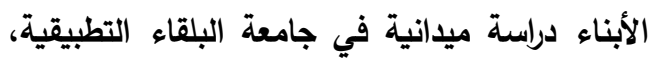


Duxbury, Linda and others. (1994). Work Family Conflict, A Comparison by Gender, Family Type, and perceived, Journal of family issues.

Gottman, J. M. (1998). Psychology and the Study of Marital Processes, Annu, Rev, Psychology.

Hampton, Gells (1994). Violence Toward Black Women in Nationally Representative Sample Families, Journal of Comparative Family Studies.

Neshat, Doost, H. and Zarga (2008). Divorce Incidence Factors in Falavarjan Township, Journal of Family Research.

Talbot, Amanda Leigh-Guinot (2011). Unemployment or Underemployment and Marital satisfaction, Analysis of Economic Strain and Religious belief in Southeastern Michigan, M.A. Dissertations, Religion, Home Economic, Michigan State University, United States.

Wolfingcr, Nicholas (2003). Parental Divorce and off Spring Marriage early or late? Annual Reviews.
نادر، دراسة مركز التغذية والتنمية الريفية (2006).

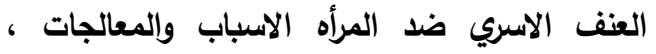

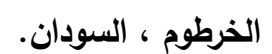

نصرت، سونيا محي الدين (2000) ـ الفقر في الريف المصري دراسة لبعض الجوانب الإجتماعية والاقتصادية للفقر في اربع قري بمحافظتي الجيزه

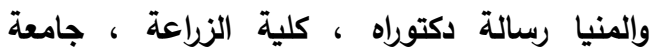

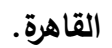

نورة، جيلاخ ، عيللي حنان (2013). تأخر سن الزواج عند الثباب الجزائري ، رسالة ماجستير ، قسم العلوم الاجتماعية ، جامعة قاصدي مرباح ورقلة. هليل، هاي مصطفي حمادة (2009). المشكلات الاجتماعية التي تواجة الاسرة الريفية في احدي قري محافظة كفر الثيخ، رسالة ماجستير ، قسم الاقتصاد الزراعي، كلية الزراعة، جامعة طنطا.

\section{ثانياً: المراجع الأجنبية}

Buss, D. M. (1991). Conflict in Married Couples, Personality Prediction of Anger and Upset, Journal of Personality. 


\title{
SOCIAL PROBLEMS OF RURAL WOMEN IN SOME VILLAGES OF MENOUFIA GOVERNORATE
}

\author{
F. A. Salama, Kh. A. A. Keneber, F. A. Mohamed and Marwa S. Alzofzaf \\ Department of Agricultural Extension and Rural Society. College of Agriculture. \\ Menoufia University - Egypt
}

\begin{abstract}
The study was mainly aimed at studying the social problems of rural women in villages of Menoufia governorate and to achieve this goal, sub-objectives were formulated that seek to identify the level of woman's awareness which was researched about the suffering of rural woman in the study area are of the studied family problems, The specific factors for the awareness of the researched woman about the suffering of rural woman in the study area are of the studied family, economic and community problems. It has been done in the governorate of Menoufia and the descriptive analytical course has been used, and the choice was on the village of Arab al-Raml from the center of Quisna and the village of Tamlai from the center of Menuf and the research was determined on house wives in those two villages in Menoufia governorate, and the sample size reached 200 in each village. A questionnaire form has been used to collect data. To analyze the study data, many statistical methods have been used, some are descriptive and others are inferred, such as repetitions and percentages, the stability coefficient Cronbach's Alpha to assess the degree of stability of multi-item variable measures, arithmetic average, standard deviation, surpassed arithmetic average, simple correlation coefficient (Pearson), and upward gradient regression. The results showed that $41.8 \%$ of rural house wives in the sample of the study that their awareness level of rural woman suffering from family problems is very high. And that $65.5 \%$ of rural house wives in the sample of the study that their awareness level of rural woman suffering from economic problems was very high. Also, $65.2 \%$ of rural house wives in the sample of the study that their awareness level of rural woman suffering from community problems is very high. The results also have revealed that there were seven separated variables affect on the level of the awareness of researched woman about the rural woman suffering from family problems in the study sample of $42.6 \%$, and the value of the multiple correlation coefficient reached $(R=0.652)$, and the value of the determination coefficient is 0.426 , there were six separated variables affect on the level of the awareness of researched woman about the rural woman suffering from family problems in the study sample by $38 \%$, and the value of the multiple correlation coefficient reached $(R=0.616)$, and the value of the determination coefficient was 0.380 , and it's shown that there were nine separate variables affect on the level of the awareness of researched woman about the rural woman suffering from family problems in the study sample of $39 \%$, and the value of the multiple correlation coefficient reached $(R=0.625)$, and the value of the determination coefficient is 0.390 . The study ended up working on doing researches in other areas and working to solve these problems and prevent their aggravation.
\end{abstract}

Key words: Social problems, Rural women, early marriage, Spinsterhood, violence against women, divorce, Poverty, Unemployment, Societal problems.

$$
\begin{aligned}
& \text { السادة المحكمين } \\
& \text { أ.د/ محمد إبراهيم العزبى كلية الزراعة - جامعة الأسكندرية }
\end{aligned}
$$

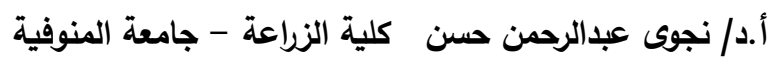

